\title{
OS ÍNDIOS E A ALFABETIZAÇÃO
}

aspectos da educação escolar entre os

Guarani de Ribeirão Silveira 
Coleção Humanidades

\section{OS ÍNDIOS E A ALFABETIZAÇÃO \\ aspectos da educação escolar entre os \\ Guarani de Ribeirão Silveira}

\section{WALDEMAR FERREIRA NETTO}

$1^{a}$ edição

Paulistana

$\sim$ Editora $\sim$

São Paulo

2012 
Copyright by Waldemar Ferreira Netto

Editora responsável

Adélia Maria Mariano da S. Ferreira

Projeto gráfico e Capa

William de Paula Amado

Revisão

Adélia Maria Mariano da S. Ferreira

Infothes Informação e Tesauro

F439 Ferreira Netto, Waldemar

Os índios e a alfabetização: aspectos da educação escolar entre os Guarani de Ribeirão Silveira. / Waldemar Ferreira Netto.

- São Paulo: Paulistana, 2012. (Coleção Humanidades)

$178 \mathrm{p}$.

ISBN 978-85-99829-42-4

1. Educação. 2. Educação Indígena. 3. Educação Guarani. 4. Índios Guarani. 5. Aldeia Ribeirão Silveira. 6. Cultura Indígena. 7. Língua Indígena. I. Título. II. Aspectos da educação escolar entre os Guarani de Ribeirão Silveira.

CDU 37

CDD 370

\section{Catalogação elaborada por Wanda Lucia Schmidt - CRB-8-1922}

Nenhuma parte desta publicação pode ser reproduzida ou transmitida por qualquer processo eletrônico, mecânico ou fotográfico, incluindo fotocópia, xerocópia ou gravação, sem a autorização prévia e escrita da Editora.

Todos os direitos desta edição reservados à

\section{Paulistana \\ Editora -}

Editora Paulistana Ltda.

www.editorapaulistana.com.br

[2012] 
Aos meninos Vadico e Leandro, ao Didiocó

e a todos os Guarani do Ribeirão Silveira 
A impossibilidade de penetrar o esquema divino do universo não pode, contudo, dissuadir-nos de imaginar soluções humanas, embora saibamos que estas são provisórias.

Jorge Luis Borges 


\section{SUMÁRIO}

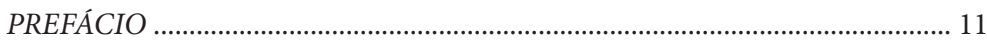

1. INTRODUÇÃO …………………………………………………………. 17

2. ASPECTOS HISTÓRICOS ………………………………………………..... 25

2.1 A educação jesuítica no Brasil .................................................................. 33

2.2 A educação jesuítica no Maranhão …………………………………….... 51

2.3 O Diretório do Marquês de Pombal ...................................................... 57

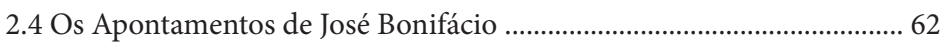

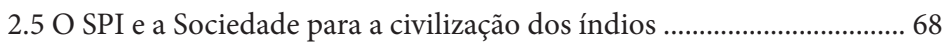

2.6 FUNAI e SIL ……………………………………………………... 74

2.7 A educação leiga ………………………………………………………….... 83

3. A EDUCAÇÃO GUARANI ……………………………………………... 93

4. ALFABETIZAÇÃO E FORMAS DE PENSAMENTO ……………………..... 127

4.1 O pensamento guarani ......................................................................... 151

4.2 Bilinguismo e educação formal entre os Guarani ................................... 158

5. CONSIDERAÇÕES FINAIS …………………………………………..... 165

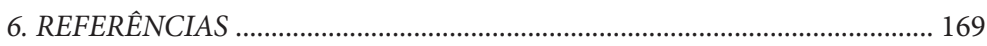




\section{Prefácio}

A primeira viagem oficial que fiz para pesquisa de campo deu-se nos dias 16 e 17 de março de 1991, para a aldeia do Ribeirão Silveira, localizada a cavaleiro dos municípios de São Sebastião e Bertioga, no estado de São Paulo. A partir desse primeiro contato, foram realizadas muitas viagens para a área, a maioria delas com duração de três ou quatro dias e, duas vezes, com duração com mais de vinte dias consecutivos. Nessas viagens pude conhecer melhor a língua falada pelo grupo Mbyá-Guarani bem como os seus próprios costumes e hábitos característicos. A comunicação que eu procurava entabular era em guarani: eles o mbyá e eu o jopará, o que me valeu a alcunha de "Paraguai", e pelo qual eu era mais facilmente identificado.

A questão da educação indígena, no ponto em que toca na língua e na linguística, pouco a pouco veio tomando a minha atenção. Primeiro, atrás do socioconstrutivismo, procurei saber sobre a aquisição da linguagem em sociedades indígenas. Segundo, atrás de um amálgama etno-historiográfico busquei compreender a documentação da língua, não só pela sua descrição "algébrico-linguística", mas também pela salvaguarda de um processo de transformação continuada e pela manutenção de seus meios de transmissão de conhecimento. Terceiro, atrás das técnicas pedagógicas da alfabetização sem cartilha, encontrei uma possibilidade de, salvaguardando as transformações continuadas na língua e na cultura, introduzir uma preocupação metalinguística no grupo ao mesmo tempo em que poderia oferecer um mecanismo eficaz e acessível para a sua autodocumentação. 
Como consequência desse percurso, minha atenção permaneceu voltada para o trabalho de alfabetização e educação indígenas e, como não poderia deixar de ser, as suas relações mais ou menos imediatas com a língua, a história e a cultura dos Guarani. Nesse caso, a etnolinguística tornou-se o novo alvo, de maneira a permitir desvendar a questão de "como alfabetizar numa língua não uniformizada"? Se a imposição de variantes de uns a outros é impossível, se não há uma forma linguística de prestígio predominando, se os nomes oscilam em seus significados, as palavras em seu comprimento e se a ordem das palavras na frase é obrigatória para mim e não para eles, havia de se encontrar um denominador comum para todos, que não passasse pela normatização externa, asséptica da língua, pois, mais que língua, ela é parte integrante de cada indivíduo guarani, adquirida desde o nascimento a partir dos processos religiosos que lhes são pertinentes. Assim a língua guarani não se permitia normatizar senão por seus próprios meios, como uma forma endógena de transformação, visando à nova realidade que se processava à sua volta.

Tomando mais a fundo essas reflexões, decidi-me por compreender as relações língua-"nação"-identidade, de maneira geral, como fenômeno humano, para verificar como ela ocorre com os Guarani, de maneira particular, mas teórica, e, com os Guarani da T.I. do Ribeirão Silveira, de maneira prática.

Assim, abandonando o projeto anterior, mas, sem dúvida, mantendo-me devedor a ele, optei pela investigação etnolinguística, no terreno da interdisciplinaridade, buscando subsídios ora na historiografia, ora na antropologia, ora na educação e ora na linguística, mas com o fito sempre imóvel em alguma maneira de promover sua unidade com um grupo historicamente diferenciado e autônomo em relação a nós.

Meu trabalho de pesquisa de campo de descrição linguística terminou por provocar um envolvimento extraprofis- 
sional entre mim e o grupo cuja língua eu queria documentar e compreender para o desenvolvimento de meu projeto. Era nos períodos que se alongavam pelo convívio, quando necessidades e satisfações do entrevistado e do entrevistador reproduziam-se, identificando a ambos pelo que tínhamos em comum, que ocorria a troca mútua de informações imprevistas e não documentáveis. Nesses momentos, desfazíamos dos papéis que academicamente nos foram estabelecidos e iniciávamos um processo de intermediações entre indivíduos, de maneira a cada um apresentar o seu conjunto de valores e de necessidades, objetivando valermo-nos, um do outro, para a solução de problemas e para a realização de anseios. Eu percorria atento todas as trilhas atrás de todos os nomes de todas as plantas e de todos os animais, meu informante percorria todos os caminhos até a cidade, atrás de todas as coisas que ele não podia comprar. À noite, as estrelas e os espaços negros do céu assumiam novas formas e recebiam novos nomes que até então eu desconhecia, ao mesmo tempo que, da esfumaçada casa de rezas, eu podia ouvir o recém-chegado rabequeiro tocar as novas cordas de aço, iluminado pelos candeeiros, agora repletos de querosene.

Nessas transformações de papéis, eu passava a informante ao falar dos números e das letras, até ler em voz alta o memorial descritivo da área ocupada por todo o grupo, para notarem que o mesmo não correspondia à realidade. $\mathrm{O}$ traçado descrito em variação de graus com relação às coordenadas norte, sul, leste e oeste, tomando, vez por outra, um riacho ou um espigão de serra como pontos de referência, precisava ser traduzido e acompanhado passo a passo por todos, para verificar que a representação textual do espaço e o espaço propriamente dito reportavam-se a realidades diferentes.

Assim, as necessidades mais prementes do grupo sobressaíam-se como protestos contrários à presença de qualquer que não fossem eles mesmos, até contra o próprio pesquisador que lhes 
chamara a atenção para o fato. Confrontavam-se a dependência obrigatória e a independência desejável no mesmo processo de leitura e de compreensão do texto, e se manifestavam no comportamento conflitoso e agressivo que os fazia aproximar-se de um tradutor/intérprete simpático à sua causa, para rejeitá-lo como o inimigo potencial minoritário, alvo mais fácil e mais bem identificável do que as empresas e os magnatas encastelados em suas empresas que só se faziam ver por seus advogados manifestos pela voz do chefe de posto da Funai.

Para eles, eu oscilava entre os dois polos, do amigo ao inimigo, quando esse caminho se tornava mais curto pela bebedeira da pinga branca que lhes embaçava a fome e o pensamento. Nesse momento, como inimigo, eu era severamente criticado em português, mas, como amigo, à semelhança de um irmãozinho mais novo que precisava aprender a língua e a maneira de seu do grupo, recebia, suave e cautelosamente, as palavras que me eram colocadas nos ouvidos. A hostilidade no convívio, nessas horas, diluía-se, entretanto, na participação mútua dos segredos, oferecidos em confiança. A língua, objeto da pesquisa, ia sendo oferecida aos poucos, em todas as situações: das falas corriqueiras do dia claro, aos cochichos noturnos entre os casais e até os mistérios de todas as origens.

Mas a troca era inevitável e imprescindível. Abandonando o academicismo que me obrigava ao distanciamento, assumi, até os limites do possível, a defesa do grupo em todas as situações, desde a compra de fumo na venda até a vinda de uma delegação de líderes para uma reunião prevista havia vários meses. Dentre o resto, a confiança inabalável no poder de documentação do texto escrito em português, que só pode comparar-se à fala deles mesmos, era ainda exclusividade da língua do outro, a minha própria língua. $\mathrm{O}$ acesso ao texto era requerido veladamente, uma vez que a aquisição de outra maneira de ser e de falar era o meio para alcançá-lo. Essa 
era a troca que se exigia e que se esperava, sem, no entanto, haver sido manifesta.

A partir dessas reflexões desenvolvi minha tese de doutoramento especialmente sobre a educação formal entre os Guarani do Ribeirão Silveira e é esse o texto que se vai ler a seguir.

$\mathrm{Na}$ pesquisa de campo, em que, muitas vezes, a atividade profissional terminou por substituir-se pelo envolvimento pessoal com o que seria o objeto da análise, sou obrigado a reconhecer uma outra dívida a um número cada vez maior de pessoas que, de uma maneira ou de outra, terminaram por contribuir para a realização efetiva de minhas investigações.

Entretanto, no meio dessa grande massa de meus credores, os quais, na maioria das vezes, desconheço, há alguns a quem a dívida parece multiplicar-se geometricamente.

Entre esses, sobretudo, o Prof. Dr. Erasmo d'Almeida Magalhães, que, além de orientar a elaboração deste trabalho, contribuiu com a maior parte dos títulos referidos na bibliografia.

Também o Samuel Didiocó, o Zé Duda, o seu Gumercindo, a Doralice, o Chico, o Armindo, o Daniel, a Sandra, o Ermenegildo, o Pibá, a dona Ana, o seu Horácio, a Paulina, o Mauro, a Lúcia, o Carlos, a Edna, o Antônio, a Cida, e todos os outros Guarani que, aos poucos, permitiram-me conhecer a sua própria maneira de pensar e de falar.

A Adélia, que repetidas vezes leu e releu os originais deste trabalho, corrigindo os erros que pareciam reproduzir-se por geração espontânea, cujos vestígios ainda devem estar espalhados pelo texto.

O Sérgio Damy, que me apresentou aos Guarani de Ribeirão Silveira e me mostrou o caminho para que eu pudesse voltar outras vezes. 


\section{Introdução}

As línguas indígenas do Brasil têm sido arroladas, frequentemente, na literatura especializada, quer como línguas moribundas, quer como ameaçadas de desaparecimento. Embora Krauss (1992) não tenha dado exemplos para essa consideração, facilmente eles poderiam ser levantados. Rodrigues (1986) reportou-se aos Koaiá, no estado de Rondônia, com menos de uma dezena de falantes. No mesmo Estado, ainda é possível acrescentar os Karipúna (TG), com a mesma quantidade. Outros exemplos dessa natureza ainda poderiam ser apresentados. Mesmo que os grupos nessas condições consigam duplicar ou até triplicar sua população, suas línguas ainda estariam correndo o risco de cair em desuso pelo número reduzido de falantes.

Krauss (1992, p. 4-7) afirmou que a língua e a produção intelectual de seus falantes são fatos necessariamente inseparáveis. Hale (1992, p. 36) considerou que a perda de uma língua e do sistema cultural que ela expressa é uma perda irrecuperável para a diversa e interessante riqueza intelectual, principal produto da indústria mental humana.

Muito embora a situação seja alarmante, é possível pensar-se, ainda segundo Hale (1992), numa reversão para esse quadro. No mesmo artigo, ele afirmou que não se deve apenas documentar essas línguas, mas também atuar educacional, cultural e politicamente para aumentar suas chances de sobrevivência, a partir do trabalho com os membros da comunidade, ajudando-os a produzir materiais pedagógicos e literários, além de promover o desenvolvimento da língua nos domínios necessários. Rodrigues 
(1992, p. 5) alerta para o fato de que 40 línguas brasileiras são faladas por menos de 40 pessoas e, portanto, ameaçadas de extinção, sendo imperioso um programa de documentação e salvamento dessas línguas e sendo necessária a revisão dos programas de educação para a comunidade indígena.

Muito próxima dessas considerações, a Constituição Brasileira, no artigo 210, parágrafo 2 , faculta às comunidades indígenas do país o acesso à alfabetização na sua língua materna, de acordo com seus métodos próprios de aprendizagem. O Decreto 26/04/91, artigos 1 e 2, e a Portaria Interministerial 559 atribuem ao Ministério de Educação e Cultura e às Secretarias Estaduais de Educação, em parceria, a responsabilidade pela educação escolar indígena. Na Lei de Diretrizes e Bases da Educação, no capítulo XV, preconiza-se que "o Sistema Nacional de Educação, preferentemente através do Sistema de Ensino da União, e com a colaboração das agências federais de fomento à cultura e de assistência aos índios, desenvolverá programas integrados de ensino e pesquisa, para oferta de educação escolar bilíngue e intercultural aos povos indígenas". Mais adiante, ainda no mesmo capítulo, item IV, afirma-se que os programas de educação indígena deverão "desenvolver material didático em línguas indígenas maternas e material bilíngue, destinados à educação em cada comunidade indígena, visando à integração do ensino em seus diversos níveis".

Meliá (1979, p. 50-60) já descreveu quais as perspectivas das sociedades indígenas quanto à presença das escolas em suas áreas e, mais especificamente, quanto ao processo alfabetizatório que se lhes propõe:

a) Dominar uma técnica a mais do "civilizado", que parece ter também um valor mágico;

b) defender-se contra a exploração salarial e nos tratos comerciais;

c) defender a própria terra com os instrumentos jurídicos documentados próprios da sociedade nacional; 
d) progredir, depois da alfabetização inicial, nos estudos e na informação de técnicas "civilizadas";

e) transmitir para a própria comunidade a técnica da alfabetização e processos seguintes;

f) prestigiar-se frente ao mundo dos "civilizados" e eventualmente conseguir melhores oportunidades de trabalho e um trato mais de igual para igual com os "civilizados" e

g) poder escrever as próprias tradições e aproveitar da leitura de textos, onde essas mesmas tradições foram já recolhidas pelos pesquisadores.

Em todas essas propostas, a educação tem sido tomada como um meio para evitar que as línguas indígenas deixem de ser usadas. Com a alfabetização em língua materna, introduzir-se-ia a escrita nos grupos indígenas de maneira a documentar suas línguas de forma definitiva e padronizada. Para tanto, a elaboração de material pedagógico e de leitura teria caráter imperioso. Aos agentes alfabetizadores caberia a tarefa de estimular o uso desse novo código, apresentando-lhes suas diversas possibilidades de uso e, possivelmente, pelo estabelecimento de mídia diversificada: bilhetes, jornais, livros, computadores, etc.

Provavelmente, esse processo envolveria a elaboração de uma escrita alfabética, com alfabeto padronizado conforme resultados de análises linguísticas e adequado aos desejos do grupo, em questões que se mostrassem polêmicas. Os textos transcritos seriam apresentados em forma de linhas e parágrafos, com orientação provável da esquerda para a direita e de cima para baixo, com as folhas se sucedendo, uma por baixo da outra. Esse material permaneceria guardado em poder do grupo, em ambientes determinados para isso.

Talvez não fosse bem assim. Mas, de qualquer maneira, haveria a inserção de uma nova técnica para a transmissão de conhecimentos que, apesar de seguir modelos eminentemente 
greco-romanos, estaria ao alcance e sob o domínio do grupo. No primeiro momento, o agente seria de fora, mas, aos poucos, formar-se-iam membros do grupo, devidamente qualificados para dar continuidade a esse processo.

Entretanto, ainda que a proposta se mostre coerente, dois aspectos devem ser considerados quanto ao desaparecimento e à manutenção de uso das línguas minoritárias. Primeiro, a ausência de documentação gráfica não implica necessariamente no desuso de uma língua. Os Guarani, por exemplo, permanecem na região metropolitana de São Paulo, com sua língua concorrendo com a portuguesa há mais de três gerações, sem que haja qualquer risco de seu desaparecimento. Segundo, não há o que possa garantir que, uma vez alfabetizados, os membros do grupo mantenham esse conhecimento no interior de sua cultura, como um dado a ser transmitido entre diversas gerações. Após quase 500 anos de contato com a língua escrita, novamente os Guarani mantêm-se completamente alheios a ela.

Em que pese o seu passado nas repúblicas jesuíticas, ou em outras reduções, cujas marcas são visíveis em vários aspectos de seu comportamento, a escrita permaneceu como um fenômeno desconhecido e desejado, sem jamais ter sido incorporado. Várias tentativas isoladas foram realizadas no decorrer dos séculos, com sucesso somente para indivíduos, mas nunca para o grupo.

O propósito deste livro é, justamente, verificar como seria possível compreender a alfabetização num contexto guarani, especificamente Mbyá. Para isso, foi realizada uma revisão geral dos propósitos educacionais alfabetizatórios, suas técnicas e seus resultados, quando possível, desde a chegada dos primeiros jesuítas até o início do último quartel do século vinte, visando à compreensão do contexto histórico da educação indígena em geral, que culminou nas propostas atuais para essa educação. 
A educação jesuítica do século XVI foi tratada a partir das cartas coletadas e organizadas por Serafim Leite. O período seguinte, século XVII e primeira metade do XVIII, referente aos jesuítas no Maranhão, foi analisado por cartas e outros documentos do padre Antônio Vieira e pela Chronica da Missão dos Padres da Companhia de Jesus no Estado do Maranhão, escrita pelo padre João Felippe Bettendorf.

O período seguinte foi a segunda metade do século XVIII. A documentação principal foi a Lei de 1755 que deu embasamento ao Diretório de Pombal e o Diretório propriamente dito. Para o Século XIX, além do texto de José Bonifácio, Apontamentos para a civilização dos índios bárbaros do reino do Brasil, as coletâneas de Documentos sobre o índio brasileiro, realizadas por Leda Maria Cardoso Naud, bem como a compilação de Legislação Indigenista Brasileira, de Maria Manuela Carneiro da Cunha, foram as bases a partir das quais se procurou conhecer alguns aspectos da educação indígena preconizada naquela época.

A educação indígena proposta no início do século XX foi compreendida a partir dos textos de Ihering, de Rondon, de Horta Barbosa, da Revista da Sociedade Brasileira de Ethnografia e Civilização dos Índios e da Coletânea de Leis, Atos e Memoriais referentes ao indígena brasileiro. A partir da segunda metade desse século, a educação preconizada pelo Summer Institute of Linguistics e pela Funai foi analisada pela documentação e pelos textos produzidos pelo próprio Summer. E, finalmente, o último período foi compreendido, principalmente, pelos relatórios publicados nas coletâneas $A$ questão da educação indígena, organizada por Aracy Lopes da Silva (1981), e A conquista da escrita, organizada por Loreta Emiri e Ruth Monserrat (1989).

Toda essa abordagem compreendeu o primeiro capítulo intitulado "Aspectos históricos". 
No segundo capítulo, "A educação guarani”, procurou-se descrever o contexto guarani no qual se inseriria a educação escolar. Ao tomar a vida religiosa guarani, foi necessário buscar, principalmente, os trabalhos de Nimuendaju, de Cadogan, de Schaden e de Meliá, a fim de estabelecer os princípios básicos que pudessem orientar minha experiência pessoal com os Guarani da A.I. Guarani do Ribeirão Silveira. A investigação de campo propiciou a compreensão dos dados etnográficos, descritos por esses autores, no contexto específico dos habitantes das aldeias do Silveira e da Boraceia. Esse cotejo permitiu encontrar dados étnicos específicos para esse grupo, muito embora acentuasse seus vínculos com a etnia maior Guarani, de maneira a evitar ter de tratá-los como fossem um "guarani genérico", salvaguardando suas especificidades. O propósito básico nesse capítulo foi o de compreender o mecanismo de transmissão de conhecimento entre as gerações e a maneira pela qual ele é compreendido pelo grupo.

No capítulo seguinte, "Alfabetização e formas de pensamento", tratou-se de estabelecer analogias, por um lado, entre o que Cassirer (1976), conceituou como "pensamento discursivo" e a noção de língua estrangeira de Bakhtin (1981) e a educação escolar de Scribner e Cole (1973); e por outro lado, entre o que ele chamou de "pensamento mítico", gerador da palavra mágica, e a noção de língua materna e a educação informal de Bakhtin e de Scribner e Cole, respectivamente. Nesse mesmo capítulo, ainda se tentou compreender a relação desses aspectos com o processo de aquisição de escrita, conforme o descreveram Emilia Ferreiro e Ana Teberosky (1980).

Os resultados dessas comparações foram aplicados ao modo de ser dos Guarani do Ribeirão Silveira, procurando-se adequar os conceitos definidos às formas comportamentais concretas que se verificou ocorrerem entre eles. A questão da escola na área foi interpretada a partir da ideia de di-ethnia proposta por Josua Fishman, em 1980. 
Finalmente, foram apresentadas algumas considerações finais, em que se tratou de fazer um balanço dos resultados obtidos.

A seleção do grupo guarani da A.I. Guarani do Ribeirão Silveira foi motivada sobretudo pelo fato de se tratar de um grupo em que, mesmo próximo de centros urbanos com os quais mantém um estreito vínculo de dependência econômica, a língua utilizada dentro da aldeia é quase exclusivamente sua língua tradicional. Contrariando a expectativa que eu tinha de encontrar um grupo com traços étnicos bastante homogeneizados em relação à população regional de seu entorno, os Guarani do Silveira mantêm os mesmos traços descritos por Nimuendaju e Cadogan. A descrição do ñeengaraí, realizada por ambos os autores, confere em detalhes com esse mesmo ritual a que assisti em janeiro de 1994. A cestaria artesanal, para uso próprio, é realizada segundo padrões de trançado que se mantêm desde as primeiras descrições realizadas por Benedito Calixto no início do século.

Durante outros trabalhos que realizei, com auxílio da FAPESP, junto dos Uru Eu Wau Wau, em Rondônia, e dos Waiãpi, no Amapá, pude vir a compreender fatos e passagens que me pareciam completamente obscuros no comportamento guarani. A presença de añã pela redondeza das casas, ou nos lugares e objetos dos mortos, como fossem resíduos das "almas" desses indivíduos, ocorre da mesma maneira entre os Guarani. A doação de filhos, sobretudo gêmeos, determinada pela ausência de um espaço social, correspondendo à morte de crianças nascidas de relações proibidas entre os Uru Eu Wau Wau, não se explicava por si só.

Muitos outros aspectos eu poderia salientar, mas fugiria demasiado do propósito deste trabalho, que se volta especificamente para a alfabetização. Entretanto, tais analogias vêm trazer à tona, principalmente, a questão de que muitos dados culturais guaranis ainda se estão por conhecer, como, por exemplo, as aves que, segundo eles, pousam sobre as costas dos cantores durante os rituais, atuando como 
intermediárias entre eles e o mundo sagrado, e que variam conforme os indivíduos; a raspagem dos cabelos como forma de se penalizar as moças que cometeram delitos conjugais; a realização de diálogos ritualizados no encontro entre líderes que não conheciam um ao outro e as relações afetivas que se estabelecem diferentemente entre os sexos.

A presença de um grupo cujas características étnicas tradicionais mantêm-se intactas, ainda que sob a pressão de um afluxo imenso de turistas no litoral norte de São Paulo, que tem valorizado suas terras vertiginosamente, chama a atenção. Ainda é necessário compreender qual foi o mecanismo que capacitou ao grupo manter-se como tal, pois, outros grupos, em situação de dependência menor do que essa, não obtiveram o mesmo resultado.

Vale lembrar que a A.I. Guarani do Ribeirão Silveira fica ao pé da Serra do Mar, e em boa parte de sua encosta. São quase 1000 hectares de solo pouco aproveitável. Na sua agricultura não itinerante, o principal cultivo, quando há, é de mandioca e algumas outras culturas isoladas, como milho, amendoim, banana, abacaxi. Nada, entretanto, é continuado. A caça é de apenas uns poucos e raros animais, às vezes uma anta, um veado, porém o comum são o gambá e o tatu. A comida de todos os dias é comprada nos armazéns da cidade. Para conseguir dinheiro vendem palmito e artesanato e, eventualmente, fazem algum trabalho externo na construção civil ou em propriedades rurais próximas. Na distribuição de trabalho entre os sexos, as mulheres cuidam da casa, dos filhos e da roça, quando há. Os homens caçam, constroem, limpam terrenos e fazem poraí.

Assim, este trabalho, além de compreender a alfabetização num contexto guarani, visa a compreender se os Guarani, que sempre se mantiveram, e ainda se mantêm, com seus traços étnicos tradicionais, ficariam sujeitos a algum desequilíbrio em suas relações de fronteira com a assim chamada sociedade nacional brasileira, no caso de terem um ambiente de educação escolar dentro de sua aldeia. 


\section{Aspectos históricos}

Com vistas a reexaminar o método da conquista espiritual jesuítica, a partir da análise da abundante correspondência, as informações, os estudos linguísticos que os padres da Companhia de Jesus produziram entre 1549 e o primeiro decênio do século seguinte, Azevedo (1976, p. 366) apresenta quatro princípios básicos para a atuação dos jesuítas:

(i) [...] instruções do Papa Gregório I, no ano 601, a Santo Agostinho monge e outros missionários beneditinos que então se dedicavam à conversão dos pagãos. (p. 367)

(ii) [...] as diretivas do Papa Paulo III [...], em dois documentos de 1537 [...] (p. 368)

(iii) [...] o Regimento que o soberano português deu ao primeiro Governador Geral. (p. 368)

(iv) [...] as ideias da época sobre as distinções morais e intelectuais entre europeus, cristãos e civilizados, e, de outro lado, bárbaros, selvagens, gentios e pagãos, que enraizavam em Aristóteles, Platão, Plínio, Lactâncio. (p. 368)

Ao se fazer uma releitura dessas quatro fontes de princípios referidas, é possível retomá-las combinadamente: duas - (i) e (ii) - reportam-se à tradição religiosa, uma - (iii) - à tradição política e uma - (iv) - à tradição intelectual portuguesa. Se considerarmos que a divisão Igreja e Estado, no século XVI, não era tomada como um traço cultural significativo para os portugueses, mas, ao contrário, a formação da "pessoa" incluía, exatamente, a formação 
religiosa e política, bem como a obediência às respectivas autoridades tradicionalmente constituídas, olhando-os pelo ponto de vista da atuação missionária efetiva, podem-se agrupar o princípio político e o princípio religioso num único traço cultural de reconhecimento e obediência a essas mesmas autoridades tradicionalmente constituídas.

Embora Fernandes (1975) afirme que os jesuítas "operavam como autênticos agentes da colonização" e que suas ações se situavam "no plano da acomodação e do controle das tribos submetidas à ordem social criada pelo invasor branco" (p. 27), a vinculação entre esse princípio de obediência política e religiosa e os propósitos mercantis coloniais subjacentes não se pode verificar no nível dos objetivos gerais e particulares que conduziam as atitudes dos padres da Companhia de Jesus no Brasil.

Agrupar os princípios políticos e religiosos traz como consequência, justamente, a desvinculação entre os princípios políticos e os propósitos mercantis coloniais subjacentes. Nesse caso, a conivência jesuítica com tais propósitos não se justifica com tanta clareza, admitindo, na realidade, duas frentes com princípios autônomos de atuação. As atuações política e religiosa dos padres da Companhia confundiam-se mutuamente num só procedimento junto das populações indígenas, seguindo rigorosamente tanto os preceitos pré-estabelecidos pela Companhia - que, direta ou indiretamente, reconhecia as diretrizes impostas pela Sé Romana -, quanto os Regimentos e as leis coloniais - que representavam os interesses da Coroa portuguesa e, portanto, também da Igreja de Portugal.

Tomar a participação dos jesuítas nas atividades mercantis da colônia como fosse uma atuação consciente e voluntária faz tábula rasa do próprio ofício missionário apostólico que conduzia os pensamentos, as atitudes e os propósitos dos jesuítas desse período. Se julgados como atores da exploração do trabalho 
indígena, ou, pelo menos, como legitimadores de sua exploração pelos colonos, a partir da conversão dos índios em cristãos mansos, confundir-se-iam as técnicas utilizadas para atingirem seus objetivos, bem como os seus próprios objetivos, com os propósitos mercantis subjacentes às práticas coloniais daquele período. Ainda que a atuação jesuítica pudesse ter sido avaliada pelas suas contribuições no sentido de colaborar com as atividades mercantis portuguesas, o projeto de comportamento que seguiam não se pautava por tais objetivos, mas pelo próprio princípio de obediência a que já se referiu.

Segundo Azevedo (1976, p. 368), a herança cultural portuguesa, bem como sua subdivisão jesuítica, estabelecendo o mundo dicotomizado em, de um lado, "europeus, cristãos e civilizados, e, de outro lado, bárbaros, selvagens, gentios e pagãos", era um prolongamento das tradições greco-romanas e judaicas (eu acrescentaria) anteriores à expansão do cristianismo no mundo mediterrâneo. Nesse caso, o projeto bíblico de evangelização do povos, sobre o qual parece ter se baseado Loyola para a elaboração das Constituciones da Companhia de Jesus, fazia parte desse prolongamento, como uma adequação ao contexto de seu aparecimento no mundo cristão.

Se essa adequação das ideias gregas e judaicas ao contexto expansionista europeu for tomada como a elaboração de um conjunto de critérios para o julgamento de todos os povos com os quais mantinham ou haveriam de manter quaisquer relações, será igualmente possível compreender a seleção desses aspectos culturais específicos como os critérios sobre os quais se estabeleceriam essas relações. Nesse caso, as tradições culturais portuguesas, readaptadas pela formação da Companhia de Jesus, assumiram um caráter mais pragmático não só selecionando valores e padrões de julgamento mas também determinando atitudes e comportamentos para os seus padres. Assim, se olhada pelo ponto de 
vista, também, da atuação missionária efetiva, a tradição cultural portuguesa pode ser agrupada ao princípio político e ao princípio religioso que pautaram a atuação das autoridades monárquicas e religiosas, projetando-se sobre o desempenho dos missionários da Companhia como o princípio da obediência.

Dessa maneira, a partir da compreensão desse nível superficial da atuação concreta dos padres jesuítas no estabelecimento das relações do império português com os grupos indígenas do Brasil, será possível compreender, de um lado, como e por que a educação (formal e não-formal) serviu de veículo para essas inter-relações, e de outro, quais as técnicas que foram utilizadas para isso e qual a eficácia que se obteve com elas.

Assim, a educação que se transplantaria para o Brasil pouco poderia desviar-se do que se preconizava em Roma; não fosse o caso insólito do absoluto desconhecimento daquilo que se esperaria encontrar nos novos mundos. A autodeterminação dos jesuítas, apesar do que se poderia imaginar devido às dificuldades de acesso e de comunicação das áreas em que se encontravam, bem como da realidade nova e inexplorada em que imergiam nas colônias, onde estabeleciam suas missões, essa autodeterminação mantinha-se fiel às determinações expressas nas Constituciones da Companhia de Jesus e na Fórmula del Instituto, ambas aprovadas na Sé Romana, pelos papas Paulo III e Júlio III, em 1540 e 1543, respectivamente.

Era o propósito da Companhia:

[...] emplearse en la defensa y propagación de la fé y en el provecho de las almas en la vida y doctrina cristiana, sobre todo por medio de las públicas predicaciones, lecciones y cualquier otro ministerio de la palabra de Diós, de los ejercicios espirituales, de la doctrina cristiana de los niños y gente ruda, y el consuelo espiritual de los fieles, oyendo sus confesiones y administrándoles los otros sacramentos. (Loyola, 1982, p. 435-436) 
Dessa maneira, a "propagación de la fé" seria mediada, dentre outros processos principais, pelas lecciones que se fariam e pela "doctrina cristiana de los niños y gente ruda". Muito embora não se deixe claro quem viria a ser essa "gente ruda", que bem poderia ser a "gente analfabeta", ou o "gentio", ou ambos, é bem possível que ele esteja a tratar dos habitantes que refere como de

\section{[...] cualquer parte del mundo adonde [el Romano Pontífice e sus sucesores] nos quieran enviar, o a los turcos o cualesquiera otros infieles, aún a aquellas partes que llaman Indias o a otras tierras de herejes, cismáticos o fieles cristianos. (Loyola, 1982, p. 437)}

A Companhia, assim, afirmava seu voto de obediência ao Papa e abria caminho para que pudesse, sob os auspícios da Igreja Católica, ir por todo o mundo, pregando o evangelho, batizando os crentes, expulsando os demônios, falando novas línguas, imortais a todos os venenos (Marcos 16, 15-18). Mas, para tanto, era fundamental que se cuidasse da formação de quem quisesse militar sob a bandeira da Companhia (Loyola, 1982, p. 435); esse deveria:

[...] mientras viviere poner delante de sus ojos ante todo a Diós, $y$ luego el modo de ser de este instituto, que es el camino para ir a El, y alcanzar con todas sus fuerzas el fin que Diós le propone, aunque cada uno según la gracia con que le ayudará el Espíritu Santo y según el própio grado de su vocación. (p. 436)

O "modo de ser de este instituto", que, segundo Loyola, é o caminho para Deus, vem descrito minuciosamente nas Constituciones. Das muitas partes que o compõem, algumas vêm ao encontro dos propósitos deste trabalho. São elas, justamente, as que se reportam ao ensino/aprendizagem de línguas novas, bem 
como aos processos de alfabetização que teriam sido empregados pelos padres da Companhia. Salientem-se as seguintes passagens, extraídas das Constituciones:

Ansi mismo se exercitarán el predicar y leer en modo conveniente para la edificación del pueblo (que es diverso del scolástico), procurando tomar bien la lengua y tener vistas y a la mano las cosas más útiles para este oficio para mejor hacerle y con más fructo de las ánimas. (LoyolA, 1982, p. 531)

Quando se hiciesse diseño en un Colegio o Universidad de preparar suppósitos para entre Moros o Turcos, la [lengua] arábiga seria conveniente o la caldea; si para entre Indios, la indiana; y asi de obras por semejantes causas podria haber utilidad mayor en otras regiones. (Loyola, 1982, p. 540)

e, ainda, outras prescrições, transmitidas por terceiros:

Y por eso ha mandado nuestro Padre que en todos los lugares donde se halla la Compañía, hablen todos la lengua de la tierra [...] (Polanco apud Loyola, 1982, p. 990)

Em todas essas passagens, a aprendizagem da "lengua de la tierra" aparece como um procedimento previsto e recomendado no modo de ser del instituto. "Tomar bién la lengua", "preparar suppósitos na sua própria língua” ou mais claramente, "[falar] todos la lengua de la tierra", descrevem com bastante precisão o uso de diversas línguas, conhecidas ou não, nos propósitos catequéticos. Ao falar em "modo conveniente" e "utilidad", o valor instrumental desse estudo aparece ressaltado.

A mesma gente ruda e os mesmos niños aparecem referidos por Loyola quando trata do juramento que fariam os ingressantes na Companhia: 
La promessa de enseñar los niños y personas rudas [...] no obliga más que los otros ejercicios spirituales [...] Pero pónese lo de los niños en el voto para que se tenga por encomiendado esto santo ejercicio, y con más devoción se haga por el singular ejercicio [...] y porque tiene más peligro de ser puesto en olvido y dexado de usar, que otras más apparentes, como son el predicar, etc. (1982, p. 556)

Como se vê, conhecer a língua da terra, ensinar a gente ruda e, principalmente, os niños, são alguns dos compromissos declarados da Companhia. O tratamento dado ao ensino dos meninos era, pois, semelhante ao dado a qualquer um dos demais "ejercicios spirituales" que deveriam ser realizados sistematicamente pelos seus membros. A ressalva de que o ensino pudesse ser mais facilmente posto em esquecimento ilustra ainda mais claramente que tal propósito deveria ter uma realização frequente entre as outras atividades previstas.

As práticas alfabetizatórias, entretanto, ocorrem apenas numa referência rápida, nas próprias Constituciones, quando as "Facultades que se han de enseñar en las Universidades de la Compañía" são tratadas:

Enseñar a leer y scribir también sería obra de caridad si hubiere tantas personas de la Compañía que pudiesen atender a todo; pero por falta dellas no se enseña esto ordinariamente.

(LoyolA, 1982, p. 540)

A condição que se colocou - "si hubiere tantas personas de la Compañía que pudiesen atender a todo" -, de forma exclusiva, permite pressupor que tal processo, apesar de "caridoso", não necessitaria ser levado a cabo pelos padres jesuítas. Corrobora com isso o fato que, para ser aceito na Companhia, era preciso ser conhecedor de letras, portanto, alfabetizado, como se pode depreender do trecho a seguir, extraído das mesmas Constituciones: 


\section{Os Índios e a Alfabetização}

Como el scopo y fin desta Compañia ser [...] predicar, confesar, y usar los demás medios [...] para ayudar las ánimas, nos pareció necesario o mucho conveniente que los que van entrar en ella sean personas de buena vida y de letras sufficientes para el officio dicho. Y porque buenos y letrados se hallan pocos [...], hallamos cosa muy difficultosa que de los tales letrados buenos y doctos pudiese ser augmentada esta Compañía $[\ldots]$

Por tanto, nos pareció a todos [...] que tomásemos otra via; es a saber, de admitir mancebos que con sus buenas costumbres $e$ ingenios diesen speranza de ser juntamente virtuosos $y$ doctos para trabajar en las viñas de Cristo. (Loyola, 1982, p. 511-512)

Aí, pode-se notar que a preferência era dada aos indivíduos já "letrados" e "doctos", apesar da dificuldade de encontrá-los em disponibilidade. A solução para esse problema parece ter sido formá-los a própria Companhia de Jesus. Em ambos os trechos, o que se pode extrair deles, também, é que a formação primária de alfabetização e primeiras letras já estava prevista como um desvio necessário das funções principais da Companhia.

A exigência da "buena vida”, entretanto, não se pode satisfazer com a formação endógena proposta. Loyola não se reporta à formação das crianças e estabelece como limite mínimo de ingresso a idade de 14 anos. Para esse ingresso, também era preconizado o total desprendimento afetivo da família:

[...] y para dar meyor ejemplo a todos de desnudarse del amor desordenado de parientes, y evitar el inconveniente de la distribución desordenada que procede del dicho amor; $y$ para que cerrando la puerta del recurso a padres y parientes, y la memoria inutil dellos, tanto más firme y establemente perseveren en su vocación. (LoyolA, 1982, p. 455) 
O que se depreende disso é que no período que precede a idade prevista para a aceitação de ingresso, o indivíduo não estava sujeito às más influências duradouras e conscientes, como $\mathrm{o}$ adulto. A criança, dessa forma, aproximar-se-ia mais facilmente do gentio e da gente ruda (Loyola, 1982, p. 435-436) do que de seus próprios pais e de seus parentes, cuja memória inútil logo deveria ser abandonada.

A Companhia de Jesus, conforme o que ficou dito, abria mão de sua vocação principal, para dividir o tempo de seus adeptos com a formação básica de novos "suppositos" de "buena vida", crianças e "gente ruda", aprendendo novas línguas, nas nações que surgiam desde o século XV.

\subsection{A educação jesuítica no Brasil}

Esse mesmo espírito apostólico dos anos que precederam a chegada da Companhia no Brasil pairava nas instruções reais. Assim, em 1539, dez anos antes da chegada de Nóbrega, o rei D. João III escrevia:

\footnotetext{
Porque o principal intento, como sabeys [...] na impresa da Índia e em todas as outras conquistas que eu tenho [...] foy sempre o acrecentamento de nossa santa fé cathólica. [...] Eu sempre trabalhei por haver letrados e homens de bem em todas as partes que senhoreo, que principalmente, fação este officio, asy de pregação como de todo outro ensino necessario aos que novamente se convertem à fee. (LEITE, 1954a, p. 102)
}

Nesse período, embora a Companhia de Jesus ainda não tivesse sido aprovada em Roma, já se preparava Fórmula del Instituto e suas primeiras determinações, menos de um ano após Loyola ter sido absolvido pelo tribunal da inquisição (LoyOLA, 
1982, p. 45). A intenção do rei português não era, pois, apoiar especialmente uma ordem religiosa, mas promover o ensino católico nas colônias. Em algumas cartas de Nóbrega é possível verificar-se que, antes mesmo de sua chegada, já havia essa atividade na colônia.

Também achamos hum Principal delles já christão baptizado [...].

(Leite, 1954a, p. 112)

Lá ha clérigos [...] (LeITE, 1954a, p. 116)

A presença de clérigos e índios batizados pressupõe a atividade religiosa referida pelo rei. A chegada da primeira missão jesuítica, no entanto, intensificaria demasiado essa atividade, expandindo-a territorialmente pela colônia e diversificando-a quanto às suas formas de consecução. O apoio real permaneceria, como se lê na doação da Sesmaria de "Água dos Meninos" feita por Tomé de Sousa:

[...] porquanto a entenção d'El-Rey e dos Padres da Companhia hee nella criar e ensinar moços do gentio, que por tempos levem o nome do Senhor a todas as gentes [...]. (LeITe, 1954a, p. 195)

Nesses primeiros momentos da educação jesuítica para o índio, no Brasil, não é possível verificar-se uma distinção entre o ensino religioso e o não religioso. Nas próprias Constituciones da Companhia, quando se diz que

El studio de Medicina y Leyes, como más remoto de nuestro Instituto, no se tratará en las Universidades de la Compañía, a lo menor no tomará ella por si tal assumpto. (Loyola, 1982, p. 549)

preconiza-se o ensino voltado para os propósitos religiosos sobre os quais se fundara o Instituto. Muito embora a alfabetização, tratada no 
parágrafo que antecede ao supra citado das Constituciones, pudesse ser tomada como um desvio desses propósitos, as próprias técnicas alfabetizatórias do período quinhentista promovem essa forma de ensino, cujo fim último será sempre o religioso. Ao analisar as cartilhas quinhentistas portuguesas, Castelo-Branco verificou que

\begin{abstract}
São na sua totalidade constituídas por duas partes distintas: uma primeira parte composta por breves páginas destinadas ao ensino do alfabeto e da soletração e, depois, uma segunda parte, sempre muito maior, contendo diversos textos destinados à prática da leitura. Ora, esses textos são quase todos eles de índole religiosa, constituindo um verdadeiro catecismo. A criança, ao mesmo tempo que aprendia a ler, aprendia a doutrina católica. (1972, p. 293)
\end{abstract}

Dessa maneira, o "ensinar a ler e a escrever", mais do que caridade, poderia participar do próprio ensino jesuítico. Mais significativa será a referência de Nóbrega às atividades alfabetizatórias de Vicente Rijo, iniciadas em menos de dez dias, desde sua chegada:

Ho irmão Vicente Rijo insina ha doctrina aos mininos cada dia, e tambem tem escola de ler e escrever, parece-me bom modo este para trazer os Indios desta terra, hos quaes tem grandes desejos de aprender e, preguntados se querem, mostrão grandes desejos.

Desta maneira ir-lhe-ey insinado as orações e doutrinando-os na fé até serem habiles para o batismo. (LEITE, 1954a, p. 110-111)

Esse vínculo, catequese-alfabetização, era tão-somente um prolongamento do espírito apostólico português que, conforme Castelo-Branco, já vinha desde o século anterior (1972, p. 294). Ainda, segundo ele, 


\section{Os Índios e a Alfabetização}

É esta mesma orientação formativa que encontramos nos textos reunidos na segunda parte das cartilhas e por isso nos parece constituírem um prova bem evidente de como a formação do homem católico, ortodoxo, foi uma preocupação dominante no Portugal de Quinhentos. (1972, p. 295)

Os textos que apareciam nessas cartilhas eram sempre de caráter religioso. Naquelas que existiam por ocasião da vinda dos jesuítas, aparecem sempre traduções portuguesas das quatro orações - Pai Nosso, Ave Maria, Salve Rainha e Credo - além de demais textos doutrinários sobre os sacramentos e outros assuntos religiosos (CAStelo-Branco, 1971, p. 111). Isso reforça o interesse jesuítico na alfabetização, uma vez que tal era um mero prolongamento das práticas catequéticas. Mesmo os índios adultos, nesses primeiros dias da missão jesuítica no Brasil, foram objetos dessa forma de ensino:

[...] ja hum dos principaes delles aprende a ler e toma a lição cada dia com grande cuidado, e em dous dias soube o A B C todo; e ho insinamos a benzer, tomando tudo com grandes desejos. (Nóbrega apud Leite, 1954a, p. 111)

Embora claramente vinculada ao propósito de se alcançar a defesa e a propagação da fé católica, a alfabetização receberia um tratamento diferenciado da catequese propriamente dita, conforme já fora previsto pelas Constituciones da Companhia. Como se verá, as práticas catequéticas serão realizadas para adultos e crianças, homens e mulheres, entre as aldeias indígenas, na língua da terra, por meio de técnicas de persuasão bastante singulares, enquanto que as práticas alfabetizatórias o serão especialmente em colégios para os meninos, na língua portuguesa, por meio de técnicas do ensino formal preconizadas pelas mesmas Constituciones. 
Logo na chegada, Nóbrega já afirmara sua disposição em fazer a catequese nas aldeias indígenas:

Temos determinado de ir vivir en las Aldeas [...] e i-los doctrinando poco a poco. (Leite, 1954a, p. 112)

Passados alguns meses, em agosto de 1549, ele já dizia:

Començamos a visitar sus aldeas [...] presentandole el reyno del cielo. (Nóbrega apud Leite, 1954a, p. 139)

Sete anos depois, em maio de 1556, ele continua com a mesma disposição:

[...] he melhor anda-los doctrinando por suas povoações a pais e filhos. (Nóbrega apud Leite, 1954a, p. 284)

Nesse aspecto, L. da Grã, seu substituto como Provincial, corrobora, quando afirma, em junho do mesmo ano:

[...] como el suegro en esta tierra tiene el marido de la hija, subiecto y los hermanos della al cuñado, a todo tiempo se la quitaria; por esso enseñar en las Aldeas es ganar a todos. (Leite, 1954b, p. 295)

Assim, o ensino catequético espalhava-se entre as várias aldeias de índios, algumas vezes com casas dentro delas para esse fim, como se depreende deste trecho de Navarro:

[...] no dexan de pedir agoa de batismo, principalmente en las Aldeas que jo enseño, dos principales de docientos fuegos, en donde tengo dos casas en las quales enseño los indios. (LeITE, 1954a, p. 180-181) 
As técnicas de persuasão utilizadas, por sua vez, desenvolviam-se conforme os próprios costumes indígenas, tanto no que toca à língua utilizada, quanto no que toca às expressões corporais e a outras formas de manifestação. De novo o Padre Nóbrega preconiza essas técnicas, quando escreve Pero Correia sobre isso:

Por todos os luguares e povoações que passamos me mandava preguar-lhes nas madrugadas, duas horas ou mais, e era na madruguada porque emtão era custume de lhe preguarem os seus Principaes e Pagés, a que elles muyto crem. (Leite, 1954a, p. 220)

Antes, porém, o Padre Navarro já as havia adotado para as doutrinas:

[...] el Pater Noster tiré en modo de sus cantares para que más presto aprendiessen y gustassen, principalmente para los mochachos, a los quales enseño que las digan sobre los dolientes las dichas oraciones, mediantes las quales se allan mejor. (LeITE, 1954a, p. 180)

Por outras práticas comuns aos costumes dos índios, também realizava-se a catequese:

Os mininos desta casa acustumavão cantar pelo mesmo toom dos índios e com sus instrumentos cantigas na língua em louvor de N. Senhor com que muito atrahião o coração dos Indios. (Nóbrega apud Leite, 1954a, p. 373)

[...] alguns mininos da terra traziam o cabelo cortado à maneira dos Indios, que tem muyto pouca differença do nosso custume, e faziam tudo para a todos ganharem. (NóBregA apud Leite, 1954a, p. 373)

e assi o pregar-lhes a seu modo em certo toom andando, passeando e batendo nos peitos como elles fazem quando 
querem persuadir alguma cousa e dizê-la com muita eficácia [...]. (Nóbrega apud Leite, 1954a, p. 407)

Logo se fez ao derredor da igreija, dizendo hos meninos huma cantigua, e respondeo o outro choro com as frautas, cousa que parecia muito bem, maxime por ser entre estes gentios que em extremo são affeiçoados à musica e cantares, e en tanto que os feiticeiros, que entre elles chamão santos, usão desta manha quando lhes querem apanhar alguma coisa. (A. Blazquez apud Leite, 1954b, p. 353)

Assim, pode-se imaginar a catequese jesuítica feita pelas madrugadas, com os pregadores batendo no peito, percorrendo a aldeia, cantando, falando na língua da terra; ou imaginar os meninos de cabelos cortados como os índios, tocando flautas em procissão pelas aldeias e cantando na língua. A língua da terra, aliás, cuja aprendizagem já fora encomendada nas Constituciones, era parte essencial dessa técnica, desde os primeiros dias da Companhia de Jesus no Brasil:

Trabalhamos de saber a lingua deles e nisto o P. Navarro nos leva avantagem a todos. Temos determinado ir viver com as Aldeias [...] e aprender com elles a língoa [...] (NóBregA apud LeITE, 1954a, p. 111-112)

Si alla tuvieren alguna manera de enseñar en lengua brasílica mandenosla porque de otra manera difficultosamente se les meterá en la cabeça, auque les bozeen cada hora y cada momento. Ellos me dizen que nuestro romance es muy trabajoso de tomar [...] algunas vezes hablo en lingua brasílica con ellos lo que sé, y contentanse mucho [...] (A. DE SÁ apud LeITE, 1954c, p. 48)

Enseñava el P. Provincial la doctrina y diálogo en lengua brasílica en algunas Aldeas, sim los que llevava en su compañía como los otros, holgavan mucho [...] (BLAzQUeZ apud LeITE, 1954c, p. 426) 
Durante todo o século XVI, essa prática se consagraria em toda a catequese colonial. No México, mais de 100 catecismos em mais de 10 línguas indígenas foram publicados entre 1524 e 1599 por franciscanos, dominicanos e outros, seguindo sempre as determinações do Concílio de Trento para os catecismos em língua vulgar: Fé e Credo, Sacramentos, Mandamentos, Pai-Nosso e orações (informação pessoal concedida pelo Prof. Erasmo d'Almeida Magalhães). No Brasil, além de uma gramática e de um catecismo na língua Kariri, o Tupi foi a língua nativa que mais se utilizou para a elaboração desses catecismos, gramáticas e vocabulário.

A associação dos jesuítas com os costumes indígenas nas práticas catequéticas não poderia deixar de resultar na reinterpretação dos próprios padres como os pajés que eles mesmos combatiam. Se nos primeiros momentos essa reinterpretação não fora tomada como tal; conforme os escritos do P. Navarro,

Estes já no hacen lo que les dicen sus hechiceros, mas como se allan dolientes llaman a nós por que les rezemos las palabras de Dios. (Leite, 1954a, p. 180),

passados alguns anos, em 1553, seria Nóbrega quem teria o tirocínio mais acertado nesse sentido:

$Y$ vale poco irles predicar y volver para casa, porque aunque algun credito den, no es tanto que baste a los desraigar de sus biejas costumbres $y$ creenos como creen a sus hechizeros, los quales a las vezes menten y a las vezes aciertan a dicer verdades; y por esso como fuere a vivier entrellos no se puede hazer fundamento de mucho fructo. (LeITe, 1954a, p. 452 grifo meu)

Do que se viu, fundados nas próprias Constituciones, os jesuítas desenvolviam sua catequese no Brasil, tomando os próprios costumes dos índios como ponto de partida. Se não 
eram todos os costumes, eram alguns que se permitiam e se aprovavam, para eliminarem-se outros que se lhes proibia.

Se nos abraçarmos com alguns custumes deste gentio, os quais não são contra a nossa fee catholica nem são ritos dedicados a ídolos, como hé cantar cantigas de Nosso Senhor em sua lingoa pello seu toom e tanger seus estromentos de musica que elles [usam] em suas festas quando matão contrairos e quando andão bebados; e isto pera os atrahir e deixarem os outros custumes esentiais e, permitindo-lhes e aprovando-lhes estes, trabalhar por lhe tirar os outros [...]. (Nóbrega apud LeIte, 1954a, p. 407)

Nesse caso, a educação catequética jesuítica surgia como uma forma alternativa de pregação, muito semelhante à dos pregadores católicos medievais que descreve Mullet:

Os dois principais esquadrões de pregadores da igreja católica medieval, as Ordens dos Franciscanos e dos Dominicanos, vestiam-se teatralmente, com seus hábitos cinzentos e pretos sobre branco. Estes pregadores profissionais eram actores dotados, numa altura em que a fronteira entre a vida e a arte não tinha ainda sido nitidamente traçada. Aperfeiçoavam as cadências da voz e os gestos para fazer valer os seus sermões. (1984, p. 41)

O propósito dessa técnica seria aproximar-se do catecúmeno para tomá-lo pelo estômago e pelo coração, tão diferentemente do racionalismo que perpassava as Constituciones e os Ejercicios Espirituales. A catequese jesuítica no Brasil orientou-se pelas folgas deixadas nas ordens de formação da Companhia. $\mathrm{O}$ "modo conveniente para la edificación del pueblo (que es diverso del scolástico)" é tomado ao pé-da-letra pela sua diversidade; além da lengua, vistas e mano, os jesuítas empenharam o corpo todo nesse propósito. 
O ensino de ler e escrever, no entanto, passou por outros caminhos que se cruzavam em alguns momentos com as técnicas catequéticas. Se a alfabetização não era um fim por si só definido, como se vê claramente nas Constituciones, era um trabalho complementar, amplamente utilizado pelos jesuítas. Como já se viu, nem dez dias se passaram, desde a chegada dos jesuítas, e já se iniciaram aulas de ler e escrever.

Por ter sido Vicente Rijo (que, depois, se chamaria Vicente Rodrigues, cf. Leite 1954a, p. 110) o primeiro alfabetizador, que mal havia chegado, deduz-se que tal alfabetização ocorria na língua portuguesa, quiçá numa das cartilhas da época. O mesmo pode-se dizer de Navarro, em aulas de ler e escrever nas aldeias indígenas próximas da Baya, pois uma grafia para a língua da terra só seria descoberta, em Porto Seguro, dois anos depois de sua chegada, como ele mesmo descreve:

En esta Capitania hallé un hombre de buenas partes, antigo en la tierra, y tenia don de escribir la lengua de los Índios que fué para mí grande consolación. Y assí lo más del tiempo gastava en dar sermones de testamento viejo y nuevo, mandamientos, pecados morales y obras de misericordia, con los artículos de la fe, para me tornar en la lengua. (Leite, 1954a, p. 279)

É de se notar que, nesses primeiros meses, a alfabetização ocorria nas próprias aldeias, para meninos e adultos. Nóbrega escrevera:

Estando un día Padre Joan de Azpicuelta [...] enseñando los niños a leer y a santiguarse [...] Esto fué luego en el princípio que començamos a enseñar. [...] Otro dia en otra aldea halló el mismo padre [...] (LeITE, 1954a, p. 140)

Nessa passagem, os termos "otro", "otra" e "mismo", referentes a "día", "aldea" e "padre", respectivamente, deixam claro que, no primeiro momento, estava "um dia", "numa aldeia", "o padre", que 
fora Navarro enquanto alfabetizava os meninos. Portanto, conforme o próprio Nóbrega escrevera, logo no princípio, quando começavam a ensinar, as técnicas da persuasão catequética valiam também para a alfabetização. Se eles alfabetizavam em português, isso se pode saber, mas se, para alfabetizar, falavam a língua da terra, não se pode ter certeza.

O fato é que ler e escrever apareciam como atividades complementares da catequese, uma espécie de chamariz para os índios. Além da já citada passagem que trata da escola de ler e escrever de Vicente Rijo, pode-se citar, dentre outras:

Començamos a visitar sus aldeias [...] Estos son acá nuestros pregones adonde nos hallamos conbidando a los muchachos a leer y escrivir, y desta manera les enseñamos la doctrina $y$ les predicamos [...]. (NóBREgA apud LeITE, 1954a, p. 139)

[...] o principal cuidado que temos deles está em lhes declararmos os rudimentos da fé, sem descuidar o ensino das letras; estimam-no tanto que, se não fosse esta atração, talvez nem os pudiéssemos levar a mais nada. (ANCHIETA apud LeITE, 1954b, p. 308)

O interesse dos índios pela escrita, que, dessa forma, já aparece manifesto desde os primeiros momentos da colonização, aparecia como mediador para os jesuítas entre os seus interesses e os interesses deles. Se foram utilizadas as cartilhas quinhentistas na alfabetização, não foi possível descobrir, mas elas teriam sido o elo dessa ligação. Não há razão para se pensar, ainda, que os próprios jesuítas portugueses alfabetizaram-se por técnicas diferentes dessas das cartilhas, tendo-se em vista que nenhum deles teria tido uma formação anterior à primeira cartilha portuguesa, cuja informação já se obteve - 1512 (CASTELO-BRANCO, 1971, p. 109). Das cartilhas anteriores à de 1534 não se tem senão notícia, mas pouco leva a crer que teriam sido muito diversas das demais. 
Em toda a correspondência que se consultou, não há referência à alfabetização de adultos, senão aquela já citada. O alvo mais próprio foram certamente os meninos da terra, os filhos dos gentios e os filhos dos portugueses.

[...] el P. Navarro tenía cargo de los ninnos, assi para los doctrinar en lo spiritual como en leer y escrevir y en las oraciones de la lengua, assi a los blancos como mamalucos y Indios [...] (V. Rodrigues apud LeIte, 1954a, p. 511)

Há na mesma casa, assi mesmo, escola de ler a alguns meninos do gentio, e com elles se ensinão outros da cidade, e de todos tem cuidado hum irmam. (NóbregA apud Leite, 1954b, p. 398)

Agrupados na mesma aula, índios, mamelucos e portugueses não poderiam ter sido tratados diferenciadamente no que toca às técnicas pedagógicas. Todos, indistintamente, eram obrigados a decorar os catecismos, as orações e demais assuntos da religião católica.

Estão estes meninos tanto adiante por aver tam pouco tempo que se começou esta obra, e respeytando as más inclinações que herdão de seus pais, porque con a conversação e magisterio dos Padres em os custumes estão modestos e muitos delles sabem as orações de cor. (BLAZQUEZ apud LeITE, 1954b, p. 352)

Están estos niños adelante asý en costumbres y buena criança, como en la doctrina y cosas de la fe. Son por todos ciento e quarenta, aunque destos no serán continuos sino los ciento, entre los quales ay algunos que saben muy bien de choro la doctrina, y un diálogo en su lengua donde está toda la substancia dela; $y$ destos se tiene ordenado que alternatim, quando viniere su vez, enseñe por su en su lengua y en la nuestra a sus compañeros la doctrina christiana. Hazénlo con tanta destreza y desenboltura como qualquiera de nosostros [...] (Nóbrega apud LeITe, 1954c, p. 132) 
As aulas, pelo que se pode notar, eram bilíngues, sobretudo quanto às práticas catequéticas, que eram aprendidas desde o início. Seriam sequenciadas, conforme desenvolver-se-iam as habilidades dos alunos, isto é, primeiro seriam alfabetizados, depois aprenderiam gramática (latina) e lógica e, então, seriam enviados à Europa.

El hermano Antonio Blazquez se occupa en enseñar a los niños a ler y escrevir, y algunos enseña grammatica. (BRÁs LOURENÇO apud LeITE, 1954a, p. 516)

El estudio se ha hasta agora continuado, mas porque ellos eran pocos y falatavan muchas veces, y el maestro aver enfermado, se an dado ferias que durarán hasta que venga el Perlado que se espera cada día, en compañía del qual esperamos que vengan algunos Hermanos que enseñes gramática $y$ lógica, porque avrá ya algunos que la pueden deprender. (A. BLÁzQUeZ apud LeITe, 1954c, p. 131)

[...] yo no pretendía recoger en las casas sino los de mejores habilidades para les enseñar también latín y después, de acá algo desbastados, poder en Hespaña aprender letras y virtud, para que buelvan después hombres de confiança [...] (Nóbrega apud Leite, 1954c, p. 362-363)

Com o estudo sendo realizado na Espanha, completar-se-ia a formação prevista para esses meninos. Se foram enviados alguns para lá, as fontes não forneceram informações suficientes para afirmá-lo; tão somente há um caso de fuga com a qual os jesuítas foram coniventes.

Quisiera llevar muchos niños consiguo y no los dexaran llevar, todavia uno se escondió debaxo de la cobierta, sin él ní ninguno saberlo, y allá vá. An de quedar maravillados quando allá por el mar saliere de debaxo. (PERo CorreA apud LeITE, 1954b, p. 71) 


\section{Os Índios e a Alfabetização}

As escolas na colônia, entretanto, pelas cifras que se fornecem, lotavam-se com mais de trezentos alunos em alguns casos:

Destes ahi cento e vinte por rol [...] (NóBRega apud Leite, 1954c, p. 52)

[...] le mande quien le ayude a la escuela, porque se va llegando el numero de dozientos alunos [...]. (BLAzQuez apud Leite, 1954c, p. 139)

Ha Escolas de trezentos e sesenta moços que jaa sabem ler e escrever. (Men de SÁ apud Leite, 1954c, p. 170)

Esses alunos todos, tirados de suas famílias, casas e aldeias, tal como se previra nas Constituciones, eram arrebanhados com o fito na separação deles dos "maus costumes" que herdariam de seus pais.

Estes entre os quais vivemos, entregam-nos de boa vontade os filhos para serem ensinados, os quais depois, sucedendo a seus pais, poderão constituir um povo agradável a Cristo. (ANCHIETA apud Leite, 1954b, p. 106)

De los niños tenemos mucha esperança, porque tomados antes que vaian a la guerra, a do van y aún las mugeres, $y$ antes que bevan y entiendan en desonestidades [...] (L. DA GrÃ apud LeITE, 1954b, p. 133)

Asy que fué este un viaje para my de mucha consolación viéndome cercado destas almas que, dexadas las casas de sus padres y madres, se venían conmigo con tanta alegria a la casa de Dios para ser enseñados en su sancta fe. (A. Rodrigues apud LeITE, 1954c, p. 121-122)

Nesses casos, a saída da casa poderia ser facilitada pelos pais, mas em outros, apesar de as cartas jesuíticas não serem objetivas quanto a isso, é possível imaginar-se o medo que sentiam os pais desses meninos, quando da chegada de um jesuíta na aldeia: 
[...] en muchas Aldeas no nos queria ver y huyan de nosostros escondiéndose con sus hijos, pensando que luego havian de morir, con gra miedo que tenian de nos [...]. (ÓRFÃos apud LeITE, 1954a, p. 387)

Mas el demonio tiene tanto de su mano aquellos ciegos, que tanto que les hablamos de sus ánimas o cosas que los interropa las luengas mentiras, que suelem contar de sus valentias, luego se van y las mugeres tomam sus hijos, aunque no tan niños, $i$ los van a esconder en los matos; y mucha me procuravão de estornar con cantigas que ellas cantan mui alto pera que sus hijos no oigan [...]. (L. DA GrÃ apud LeITE, 1954b, p. 133)

O medo das mães as fazia esconder seus filhos ou impedir que fossem persuadidos pelos jesuítas a fugir para junto deles. A eficácia, nesse caso, das técnicas da catequese pode ser observada. Essas fugas foram referidas pelos padres:

Ja comieçan los hijos de los gentiles a huyr a sus padres $y$ venirse a nós [...] (PIREs apud LeIte, 1954a, p. 258)

Entre estes se achou hum que, vendo vir a sua mãy, se escondeu entre o arvoredo, e dizia depois ao Irmão que ainda que sua mãy o quisera levar por força, que não se ouvera de ir com ella... Outros meninos em a idade bem pequenos enganarão a seus pais, dizendo que hião a nadar pera ter ocasião de se vir com o Irmão. (BLAzQuez apud LeITe, 1954b, p. 80)

Tal fato justificava semelhante medo, mas, além disso, chama a atenção para a eficácia das formas de persuasão de que se valiam os jesuítas para provocar essa adesão espontânea por parte dos meninos. Mesmo depois, já na escola, os meninos mantinham-se distantes dos pais, como se pode notar nos trechos seguintes: 


\section{Os Índios e a Alfabetização}

Este minino será de doce annos. Sabe ia leer e escrivir honestamente, no quiere ver a los suios [...] (Pires apud LEITE, 1954a, p. 399-400)

Estamos como les he scripto en esta Aldea de Piratininga donde tenemos un gran escuela de niños, hijos de indios enseñados ya a leer y escrivir, a aborrecen mucho las costumbres de sus padres, y algunos saben ayudar a cantar la missa. (ANCHIETA apud LeITE, 1954b, p. 81)

É de se notar que, no próprio Regimento do Governador, elaborado um ano antes da sua vinda, de maneira muito semelhante às proposições da Companhia para o isolamento dos meninos, consta o trecho:

\footnotetext{
Eaos meninos, porque neles se imprimirá a doutrina, trabalhareis por dar ordem como se façam cristãos e que sejam ensinados e tirados da conversação dos gentios. (LeITE, 1954a, p. 7)
}

Como tal se pôde ver, contando com o apoio legal para promover a separação dos meninos de suas famílias, a educação fazia-se valer de todos os meios para a realização dessa tarefa. Considerando-se a ressalva definida nas tarefas a serem executadas pelos padres da Companhia, previstas nas Constituciones, de que a edificação dos meninos, várias vezes referidos nas cartas como de escola, mais se aproxima da formação dos próprios padres da Companhia do que daquela realizada nas aldeias. Havia aí um processo catequético que se poderia dividir em duas partes: primeiro, a recolha dos meninos nas aldeias a partir dos meios de persuasão catequética desenvolvidos pelos jesuítas, que os fazia ir às escolas, acompanhando espontaneamente os padres e irmãos jesuítas; e, segundo, a formação escolar das aulas de ler e escrever, de gramática, de língua latina e de outras letras, inclusive na Espanha, com certeza para formá-los novos “soldados pera Christo" (NóBrega apud LeITe, 1954a, p. 402). 
A eficácia das técnicas empregadas em ambas as partes desse processo catequético deve ser avaliada separadamente quanto a cada uma. Como se viu, as técnicas de persuasão catequética realizadas nas aldeias obtiveram resultados bastante evidentes ao se tomar o número de alunos que chegaram a frequentar os colégios jesuíticos nesse primeiro momento - até trezentos e sessenta, segundo Mem de Sá, talvez com algum exagero. O próprio temor dos pais desses meninos, evitando, inclusive, que seus filhos ouvissem as pregações e os argumentos dos jesuítas, bem como as fugas espontâneas dos meninos para ir às escolas, são dados muito expressivos no sentido de comprovar a eficácia dessas técnicas. A educação escolar jesuítica para os filhos dos índios, por sua vez, que poderia ser tomada pelas aulas de ler e escrever e de decorar a doutrina, foi referida em várias passagens como tendo sucesso, isto é, os meninos aprendiam a ler e a escrever e sabiam a doutrina de cor.

Entretanto, deve-se ressaltar a ineficácia do produto final desse processo, ou, mais propriamente, da "edificação" dos meninos que passaram sequenciadamente por diversas etapas da escolarização, como bem se pode notar nesses trechos de Nóbrega e de Anchieta:

Estos mochachos despues que crescen, buelven a la misma de sus padres que antes tenían, en partes donde no tienen subjetión. (Nóbrega apud LeITE, 1954c, p. 360)

[...] aunque al principio, quando estavan todos juntos, algún fructo se hazia en ellos, maxime en las mugeres y niños, despues que se dispargieron por diversas partes [...] ni se les puede acudir con doctrina, ni (lo que es peor) ellos la quieren [...] Verdad es que hazen grandes fiestas en la matança de sus enemigos ellos y sys hijos, etiam los que sabian leer y escrivir [...]. (ANChieta apud Leite, 1954c, p. 370-371)

A declaração de Anchieta vai bem de encontro à de outro momento da educação para o indígena, quando o propósito era trazer os meninos para as aulas: 


\section{Os Índios e a Alfabetização}

O ensino dos meninos aumenta dia a dia e é o que mais nos consola; os quais vêm com gosto à Escola, sofrem açoites e têm emulação entre si [...]. (ANCHIETA apud Leite, 1954b, p. 194)

Nem mesmo os castigos corporais, nesse caso, assustavam os meninos das escolas, muito embora a técnica parecesse temível a Luís da Grã:

[...] solo el ver dar una palmatoriada a uno de los mamalucos basta para uno se ir. (LeITE, 1954b, p. 136)

A tão pretendida salvação das almas não se obtinha, pois, pelo conjunto das técnicas utilizadas. Os meninos eram conquistados nas aldeias, iam com interesse para as aulas, aprendiam a ler e escrever, decoravam as orações, os catecismos... Tudo isso não era suficiente para a conversão completa. Nóbrega aponta para uma causa possível para isso, quando escreve que os meninos ("mochachos", ele diz), ao crescerem, retornavam à vida de seus pais, em "partes donde no tienen subjetión". Também Anchieta aponta para a dispersão dos índios como causa para essa volta ao costumes tradicionais. Quatrocentos anos depois, Novaes (1990) reconheceria o mesmo comportamento entre os Borôro:

Os jovens Bororo, que eu mesma conheci em 1970 e que passavam a maior parte de seu tempo jogando futebol ou truco, fofocando no porto indígena, participando apenas dos forrós realizados na sede do posto e completamente alheios aos rituais que os Bororo tradicionalmente conduzem, tinham, passados dezesseis anos, uma atitude completamente diferente. Demonstravam, agora, profundo interesse pela cultura Bororo, participavam ativamente de seus rituais, recorriam com facilidade a mitologia e, pouco a pouco, começavam, eles também, a utilizar o discurso não só saudosista, como também de crítica às gerações mais jovens... "Plus ça 
change..." Talvez seja assim mesmo que as coisas mudem nestas sociedades. Ser o mesmo, de modo diverso. (p. 77)

Se, para os índios, a alfabetização era o fim e para os jesuítas era o meio, somente a sujeição pela força, como de fato, posteriormente, ocorreria, garantiria a formação completa dos meninos preconizada pela Companhia. O retorno à vida tribal independente, nos moldes tradicionais de cada grupo, assegurava aos índios, como até hoje assegura, a posse de sua identidade manifesta por suas ações e formas de pensamento, tais como teriam adquirido de seus antepassados, apenas acrescidas e modificadas por novas informações e novos instrumentos. O que não se propôs, nessa primeira tentativa da educação para o indígena, por todos os motivos que a história define, foi um acerto de interesses e capacidades: os índios queriam a alfabetização e os jesuítas sabiam persuadir.

\subsection{A educação jesuítica no Maranhão}

No século que sucedeu essa educação jesuítica, a educação para o indígena não poderia deixar de trilhar os mesmos caminhos, apesar de ser uma tarefa estendida a outras mais ordens religiosas, cujos fins últimos das práticas educacionais aplicadas divergem muito pouco, ou nada, daquelas que já foram propostas anteriormente. Muito embora a catequese se mantivesse como negócio de Estado, diretamente sob a tutela do Rei, auxiliando a Igreja na evangelização dos indígenas; também a Igreja fornecia ao Estado suprimento necessário para sua formação e sustentação. Assim, se a preparação de mão de obra para o trabalho escravo colonial não era intento declarado da atuação missionária e, por conseguinte, da Igreja, havia uma atuação intencional paralela, mais de acordo 
com a sua própria constituição, que unia o mundo português ao mundo sagrado do cristianismo. Bettendorf, por exemplo, ao narrar uma batalha contra os franceses, no norte do Maranhão, justificou a vitória dos portugueses, segundo ele, em desvantagem, pela intervenção direta do mundo cristão sagrado:

\begin{abstract}
Attribuiram todos este bom sucesso à Virgem Nossa Senhora por apparecer entre elles em a peleja uma magestosa e valorosa mulher, a qual andava de cá para lá, e ia repartindo a pólvora e balas de seu regaço aos Portugueses, animando-os a pelejar com valor, de sorte que tendo vindo sobre eles tresentos Francezes, não escaparam mais que cincoenta dellos com vida para poderem levar a nova de sua triste dita ao Governador da fortaleza o Senhor La Ravardière ficando só tres mortos da parte dos Portugueses por milagre manifesto. (BETTENDORF, 1909, p. 9)
\end{abstract}

Assim, a Igreja e o Estado continuavam como um único corpo não só política e economicamente, mas também pela própria concepção de mundo do pensamento missionário.

Do trabalho jesuítico do século anterior não se podia esquecer, voltando à tona, sobretudo pela experiência que se transferia. Vieira se recorda de Nóbrega, ao descrever e incentivar a técnica de ensino por "música e harmonia de vozes" (1992, p. 149), e censura qualquer tentativa que não queira "seguir em nada o estilo, que a experiência tem ensinado em tantos anos" (LeITE, 1940, p. 309). A reprodução das práticas desenvolvidas nos primeiros anos de missão mantinha a educação como um processo continuado no tempo, que não perdia sua coesão interna. Qualquer tentativa de se romper essa continuidade era de pronto censurada.

Para o ensino religioso, mantinham-se as mesmas técnicas de uso da língua materna tanto nas prédicas quanto na elaboração 
de catecismos e de gramáticas - para o melhor conhecimento das línguas em que se haviam de pregar. A disposição missionária de levar a cabo a evangelização dos gentios obrigava-os, quaisquer que fossem os custos, a aprender logo a língua da terra (BETTENDORF, 1909, p. 330), "não infusas pelo Espírito Santo, mas aprendidas com imenso trabalho" (Vieira apud Edelweiss, 1969, p. 196).

Dessa maneira, o trato com os índios parecia manter-se na própria língua que falavam. $\mathrm{E}$ a educação, com certeza, devia seguir pelo mesmo caminho. Entretanto, a documentação relativa aos processos educacionais no século XVII é muito menor do que a do século anterior. As referências são esparsas e casuais, denunciando que a euforia inicial das tentativas de conversão, tão marcadamente registradas nas cartas que se analisou, já havia desaparecido e se dispersava entre as várias ordens e igrejas que concorriam para o mesmo fim.

No Recife de Pernambuco, que era a corte e empório de toda aquela Holanda, havia judeus de Amsterdã, protestantes de Inglaterra, calvinistas da França, luteranos de Alemanha e Suécia, e todas a outras seitas do Norte: e desta Babel de erros particulares se compunha um ateísmo geral e declarado, em que não se conhecia outro Deus mais que o interesse, nem outra lei mais que o apetite; e o que os fugitivos de Pernambuco trouxeram e vieram ensinar à serra... (VIEIRA, 1992, p. 131-133)

As técnicas de ensino, no entanto, não parecem ter mudado. Muito pelo contrário, parecem ter sido ainda mais voltadas para as condições locais, mesmo no caso da alfabetização, como mostram as seguintes passagens de Bettendorf:

[...] e porque, por falta de livros tinta e papel, não deixassem de aprender, lhes mandei fazer tinta de carvão e summo de algumas ervas, e como ella escrevia em as folhas grandes de pacobeiras e para lhes facilitar tudo lhes puz um pauzinho na 


\section{Os Índios e a Alfabetização}

mão por penna, e os ensinei a formar e conhecer as letras assim grandes como pequenas no pó e arêia das praias. (BETTENDORF, 1909, p. 156-157)

Acabadas as funções ordinárias, que eram doutrinar, fazer casamentos e baptismos e ajudar aos moribundos e consolar os vivos, animando-os todos com umas dadivasinhas e gotas de aguardente que estimam sobre todo (p. 261)

Mas também não há qualquer referência específica à língua em que se ensinava nem ao que era ensinado, ou até escrito. Numa passagem rápida, o mesmo Bettendorf falou no ensino da língua portuguesa aos meninos, do que se presume que a língua era ensinada a partir da própria alfabetização.

ensinar aos meninos a língua portuguesa, para com isso se poderem bem doutrinar, depois elles a seus filhos, visto não terem noticia de sua língua por não a ensinarem seus pais, aos quaes acodem por intérpretes. (1909, p. 11)

A separação das crianças de seus pais, tanto cultural quanto fisicamente, era ainda preconizada para o propósito de cristianizar os índios. A convivência da criança na sua própria família permanecia, na interpretação missionária, como uma influência perversa, cuja esquivança, por qualquer meio que fosse, seria louvável:

[...] nenhum pai houve que não trouxesse a batizar todos os filhos, dos quais muitos foram logo chamados ou arrebatados ao céu antes dos anos do entendimento, para que a malícia dos mesmos pais não lhos pervertesse. (VIEIRA, 1992, p. 150)

O mesmo interesse dos índios na alfabetização, que garantiria a eficácia das técnicas empregadas, pode ser visto também em várias passagens de Bettendorf: 
[...] juntaram-se muitos dicipulos e entre elles o capitão Jacaré; e são estes hoje os mais autorizados e velhos da aldêa (os meus discipulos). (1909, p. 156-157)

[...] gostaram tanto que enchiam a aldeia e as praias de letras, ficando toda aldêa e praias alastradas todas. (1909, p. 156-157)

A catequese, entretanto, não parecia obter os mesmos resultados, pois, se a lógica dos índios para a compreensão do mundo já se estabelecera havia milênios, fornecendo-lhes um lastro capaz de assegurar-lhes a integridade diante dos demais grupos, as novas informações fornecidas pelos missionários terminavam tão somente por incorporar-se ao pensamento indígena, sem se transformarem em suas substitutas. Assim, as ideias cristãs se iam tomando de empréstimo, junto com suas palavras, e complementando os espaços vazios gerados pela nova situação de contato, que o conjunto de ideias e palavras anterior não poderia complementar. Os padres continuavam como pajés, rezando sobre os moribundos as orações da igreja (BetTendorf, 1909, p. 418) ou sendo instados a excomungar os mosquitos para que se retirassem para outra parte (p. 261). Mas é Vieira quem ilustra melhor essa incorporação, num trecho mais longo que vale reproduzir:

Por outra via, tinha já procurado o demônio tirar-lhes do pensamento a fé e o temor do inferno, espalhando entre eles um erro aprazível semelhante à fábula dos Campos Elísios, porque dizem que os três principais das aldeias da serra têm debaixo da terra outras três aldeias muito formosas, onde vão depois da morte os súditos de cada um, e que o abaré ou padre, que lá tem cuidado deles, é o padre Francisco Pinto, vivendo todos em grande descanso, festas e abundância de mantimentos; e perguntados donde tiveram esta notícia, e se lhes veio algum correio do outro mundo, alegam com testemunha viva, que é um índio muito antigo, e principal entre eles, o qual diz que, morrendo da tal doença que teve, fôra levado ás ditas 


\section{Os Índios e a Alfabetização}

aldeias; por sinal que uma se chama Ibirupiguaia, outra Inambuapixoré, a terceira Anhamari, e que lá vira todos os que antes dele haviam morto, e entre eles a sua mulher, a qual o não quisera receber, e pelejaram com ele por ir desta vida sem levar um escravo que a servisse, e que depois disso tornara a viver. O índio, por sua pouca malícia, parece incapaz de haver composto esta história, e assim julgam os padres que foi sem dúvida ilusão do demônio para o enganar a ele, e por meio dele aos outros, e quando menos, para pôr em opiniões um ponto tão importante como o do inferno. (VIEIRA, 1992, p. 166-167)

O inferno cristão foi reinterpretado e, com ele, o próprio padre que parece tê-lo apresentado ao grupo, que o tomou e o acrescentou às suas próprias tradições, transformando-as, pelo menos aparentemente, para melhor se adaptarem à nova realidade que teriam de explicar. Assim como ocorria essa reinterpretação pelos índios, também ocorria pelo jesuíta que apenas entendia ter sido isso obra do demônio. Um etnocentrismo mútuo percorria todas essas relações, colocando índios e padres em planos paralelos, para os quais os processos de educação e de aprendizagem atuavam somente como um mecanismo de contato e de interação no intercurso entre grupos distintos.

Assim, se o desejo de manter as práticas educacionais continuava comum para os dois grupos em contato, facilitando o emprego da mão deobra indígena nos povoados (BETTENDORF, 1909, p. 80), à medida que os próprios índios iam "uns a pedir Padres para as suas terras, outros a oferecer-se a descer" (VIEIRA apud LeITe, 1940, p. 255), a diferença de propósitos que se esperava obter com tais práticas ainda não as mantinha duradouras. Como no século anterior, índios e padres reuniam-se desconcertadamente em torno de técnicas pedagógicas que se consagrariam futuramente - o uso da língua materna no meio do grupo, o ensino sistemático do português como língua de contato, a formação de centros exclusivos 
para as práticas de ensino e aprendizagem, a adequação material do ensino à realidade dos educandos, etc. - , mas que, no seu conjunto, não atendiam às necessidades indígenas como instrumentos capazes de melhorar seu desempenho na interação com os portugueses.

\footnotetext{
Daqui tomou ocasião o demônio, [...] metendo na cabeça de todos os principais que os padres [...] eram espias dissimulados dos portugueses para avisarem do que se passava na serra, e, quando estivessem mais descuidados, os entregarem a todos em suas mãos, os maiores para serem justiçados pelos delitos passados, e os outros para serem vendidos por escravos em perpétuo cativeiro. (VIEIRA, 1992, p. 151)
}

Do interesse na presença dos padres dentro de suas aldeias para a sua rejeição como inimigos e traidores de sua pátria, de suas vidas e de suas liberdades (p. 152), o caminho percorrido foi o da consciência do desacordo de propósitos, que se comprovava na vida política e econômica da colônia. Ainda que os próprios padres se insurgissem contra a escravidão indígena, a insistência na tentativa de se coibi-la denuncia a sua efetiva realização. Muito embora os padres pudessem ser incorporados às tradições dos índios, não perdiam para estes a mesma identidade dos demais portugueses e, portanto, a de inimigos potenciais.

\subsection{O Diretório do Marquês de Pombal}

A partir do século XVIII, a documentação relativa a educação para o indígena torna-se ainda mais voltada para o foco de sua elaboração e menos para o de sua realização e avaliação. A lei de 1755, entretanto, que dá embasamento para o diretório de Pombal de 1757, recupera o que já se notava das técnicas de ensino e catequese que os religiosos realizavam nas aldeias. 


\section{Os Índios e a Alfabetização}

[...] até agora não só se não tem multiplicado, e civilizado os Indios daquelle Estado; desterrandose delle a barbaridade, e o gentilismo, e propagandose a doutrina Christã, e o numero dos Fieis allumiados da luz do Evangelho; mas antes pelo contrario todos quantos Indios se descerão dos Sertoens para as Aldeas em lugar de propagarem, e prosperarem nellas de sorte, que as suas commodidades, e fortunas servissem de estimulos aos que vivem dispersos pelos matos para virem buscar nas povoaçoens pelo meyo das felicidades temporaes o mayor fim da bemaventurança eterna, unidose ao gremio da Santra madre Igreja; se tem visto muito diversamente, que havendo descido muitos milhoens de Indios se forão sempre extinguindo de modo, que he muito pequeno o numero das povoaçoens, e dos moradores delas; vivendo ainda esses poucos em tão grande miseria, que em vez de convidarem, e animarem os outros Indios barbaros a que os imitem, lhes servem de escandalo para se internarem nas suas habitaçoens silvestres com lamentavel prejuizo da salvação das suas almas, e grave damno do mesmo Estado, não tendo os habitantes delle quem os sirva, e ajude para colherem na cultura das terras os muitos, e preciosos frutos em que ellas abundão. (Moreira Neto, 1988, p. 152)

A ineficácia dos processos educacionais missionários aparece agora constatada pelo monarca e sua equipe consultora. A consciência de que os descimentos não surtiram o efeito evangelizador e civilizador que se imaginava, mas, ao contrário, criaram tão somente uma população marginal e etnicamente diferenciada, que não atendia a nenhum dos propósitos desses descimentos, isto é, a formação de mão de obra e a propagação da fé cristã, desencadeou uma mudança de atitude na relação do estado com o indígena.

A causa primeira que se procurou combater era não se "haverem sustentado efficazmente os ditos índios na liberdade" (p. 152). Novamente, proíbe-se a escravidão indígena e recomenda-se o que já era praticado havia um século e meio: 
[...] procurar trazer ao gremio da Igreja aquelle numereo Paganismo; e muitas das Naçoens daquelles Gentios estão em partes mui remotas, vivendo nas trévas da ignorancia, e difficultosamente se persuadirão a descer para as Povoaçõens que até agora se achão estabelecidas; para que ainda no interior dos Sertoens lhes não falte o Pasto espiritual: hey por bem que nelles sejão aldeados na sobredita fórma; levantando-se Igrejas, e convocando-se Missionarios, que instruam os ditos Indios na Fé, e os conservem nella. (p. 161, grifo meu)

A reiteração de um fato como esse - convocar missionários que, no interior dos sertões, levantem igrejas e que instruam os índios na fé cristã - indica um distanciamento entre Estado e as práticas missionárias efetivamente realizadas na colônia. Alguns anos depois, o Diretório de 1757 consolidava esse distanciamento, abolindo "a administração Temporal que os Regulares exercitavão nos Índios das Aldeas” (p. 166), atribuindo-a a Diretores nomeados pelo Governador e Capitão General do Estado. Assim, apesar de a divulgação do evangelho ser o intento principal do rei, a doutrina cristã aparecia, ao contrário do que se sucedera anteriormente, vinculada à educação; esta, prioritária sobre aquela.

E como esta determinação he a base fundamental da Civilidade, que se pretende, haverá em todas as Povoaçoens duas Escólas públicas, huma para os Meninos, na qual se lhes ensine a Doutrina Christãa, a ler, escrever, e contar na fórma, que se pratica em todas as Escolas das Naçoens civilizadas; e outra para as Meninas, na qual, além de serem instruidas na Doutrina Chrstáa, se lhes ensinará a ler, escrever, fiar, fazer renda, cultura, e todos os mais ministérios próprios daquele sexo. (p. 169)

Entretanto, se a obstância à participação missionária fora proposta na educação para o indígena, suas práticas pedagógicas seriam a base da tentativa de implantação do projeto pombalino. 
Novamente, preconizava-se o isolamento das crianças de suas famílias:

[...] enquanto os índios se forem educando na companhia dos pais e como o leite dos seus próprios vícios, por maior diligências que se façam tarde se verão civilizados, porque o mal depois de habituado com a natureza se diz incurável, é pelo contrário, de mais fácil remédio antes de criar raízes: [...] e a experiência mostra evidente naqueles índios apreendidos no mato que se vão criando na companhia dos brancos tanto mais pequenos tanto mais cedo civilizados. (Joseph Xavier Machado, Desembargador Ouvidor da Comarca de Porto Seguro, apud Naud, 1970, p. 492)

O isolamento das crianças, com ou sem o consentimento dos pais, permanecia como uma prática educacional corrente, levando-as para escolas construídas com essa finalidade. A divisão em escolas para meninos e escolas para meninas permanecia, também, à semelhança da proposta jesuítica do século XVI, com prioridade para a dos meninos.

\footnotetext{
[...] enquanto as fêmeas como nesta capitania não há mestras destinadas para as ensinarem a ler e escrever; nem lhes é tão preciso, exceto para saberem a língua portuguesa (o que se vai remediando com se distribuírem pelas casas de mulheres particulares com que pelo uso a vão aprendendo). (p. 493)
}

Ao que parece, saber a língua portuguesa implicava o conhecimento da leitura e da escrita, pelo menos para os meninos. Às meninas, uma educação sempre diferenciada, orientada sobretudo pela atividade prática e não discursiva. A sequência das roupas que deveriam receber de suas mestras e amas, até o casamento, ápice da educação, é significativa quanto ao comportamento que se esperava dessas meninas: 
No primeiro ano lhes contribuam as mestras e amas além do sustento com o simples vestuário quotidiano de camisa, e saia de algodão grosso de modo que nunca se vejam nuas, nem rotas; e no segundo mais com uma camisa de linho, e saia de alguma droga para o Domingo; e no terceiro com sua capa, lenço, fita de cabelo, e sapatos ou chinelas. (p. 494)

Em três anos, as meninas passariam, portanto, de uma camisa e uma saia de algodão grosso para uma camisa de linho, uma saia leve, sapatos, capa, lenço e fita no cabelo. As meninas adultas, "comumente desonestas" na opinião do Ouvidor de Porto Seguro (NAud, 1970, p. 490), tinham o casamento como o ponto de chegada de todo o processo educacional pelo qual teriam passado.

Das técnicas pedagógicas, apenas o uso da língua materna como veículo de ensino e de comunicação foi completamente transformado pela proposta pombalina. O uso da língua portuguesa seria um dos principais cuidados dos Diretores das aldeias, o que parece ter tido os resultados esperados, pelo menos em Porto Seguro, em que, segundo o mesmo ouvidor: "a mocidade já vai de todo esquecido o uso da língua bárbara“" (p. 490).

Quanto à expectativa dos índios dessa forma de educação, nos dados analisados, não há informações que permitam verificá-la. Mas, como já se afirmou, o foco dessa educação estava mais voltado para a sua elaboração do que para sua realização. Assim, se a educação missionária dos séculos anteriores incorrera no erro da inadequação de seus propósitos de ensino com os propósitos da aprendizagem indígena, a educação pombalina distanciava-se ainda mais dessa confluência de interesses.

Desde a insistência do rei na formação de missões onde já havia missões até o estabelecimento de uma "ação civilizadora" - diferentemente da ação evangelizadora intrínseca da religião cristã -, como fosse uma necessidade própria de todos os povos, a simpatia do índio pela escrita, bem como por outras demais 
técnicas que lhe serviriam de apoio em suas interações com o mundo português, ou com outros, tornara-se mero acidente. A educação não se fazia para o educando, mas para o próprio educador, que, sozinho, criava essa necessidade e sua satisfação.

\subsection{Os Apontamentos de José Bonifácio}

No prosseguimento da educação pombalina, cujo Diretório termina por ser abolido em 1798, o século XIX assiste às ecléticas tentativas de se elaborar propostas de educação para o indígena que reunissem os pretendidos sucessos da educação praticada pelos missionários, com o racionalismo inaugurado pelo Marquês de Pombal. Beozzo reportou-se a essa divisão de pontos de vista:

\footnotetext{
Na documentação dos séculos XVI e XVII, o índio é antes de tudo o 'gentio', que se contrapõe a 'cristão', e o principal agente da empresa de 'redução' do gentio à fé e à vassalagem do Rei é o missionário. Para o século XIX o índio é o 'selvagem', que se contrapõe a 'civilizado', e por isso, ainda que o agente empregado possa ser o missionário, sua tarefa é mais civilizatória do que evangelizadora. Trata-se mais de integrar o índio à vida social pela instrução, tornando-o economicamente produtivo na lavoura do que à vida da Igreja pela catequese. (1983, p. 81)
}

Embora fosse possível adiantar em quase meio século a proposta 'civilizadora' para o indígena, o que se toma por fundamental nas considerações de Beozzo é a constatação de que a educação para o indígena atinge foros para além da igreja, sem que o vínculo fosse abandonado. A participação continuada da Igreja nesse processo, ainda que de par com a leitura, a escrita e a aritmética, é marcada pela desejada presença missionária no meio indígena. A mudança de objetivos — da 'evangelização' para 
a 'civilização' - não provocou nenhuma mudança nas técnicas previstas para a implantação das ideias civilizadoras.

José Bonifácio, em 1823, repetia Vieira e afirmava que "é preciso pois imitar e aperfeiçoar os methodos de que usarão os Jezuitas" (SiLva, 1963, p. 58). Nos seus Apontamentos, ele salientou e preconizou a imitação das maneiras dos feiticeiros (p. 63); a instrução dos missionários na língua geral, ou no guarani ou nas demais (p. 65); a vinculação do ler, escrever e contar com a catequese cristã (p. 68); a priorização do ensino escolar para as crianças (p. 68), deixando aos velhos a catequese política e religiosa. Em correspondência enviada para o corregedor Francisco Albuquerque, em 1827, Oliveira (apud NAUD, 1971, p. 307) salienta que "quando seriamente se quizesse tenctar a sua civilização mais seria preciso mais, que consultár a marcha dos sabios Jezuitas".

A educação para o indígena aparece, pois, atrelada à educação religiosa, ainda que, nem sempre, houvesse referência à jesuítica. O próprio príncipe, em 1808, ordena que eclesiáticos virtuosos, "a serviço de Deus e meu", se encarreguem da educação religiosa e civil (Cunha, 1992, p. 62); José Bonifácio, em 1823, propõe a criação de "escolas de primeiras letras para os lugares, onde não baste o Missionario para este ensino" (SILVA, 1963, p. 171). O tenente coronel Marlière, em 1826, lembra que aos missionários fará gosto ensinar como em escolas para a mocidade indígena (NAUD, 1971, p. 313); o imperador, em 1835, ordena que um padre missionário instrua os índios nos deveres da religião e exerça, “a beneficio dos mesmos indios o logar de mestre de primeiras lettras" (CUnHA, 1992, p. 119). Em 1866, ao autorizar o estabelecimento de missões no Maranhão, o imperador também determina:

ao missionário, compete:

$\$ 1^{\circ}$ A cathequese e direção espiritual tanto dos Indígenas aldeados em Missões, como d’aqueles que de novo a quiserem abraçar [...] 
$\$ 6^{\circ}$ Ensinar a lingoa vulgar, e as primeiras letras aos filhos dos Catechumenos [...]. (Cunha, 1992, p. 175-176)

É de se esperar, pois, que, apesar da distinção que se propõe entre uma educação civil e uma educação religiosa, pouco se possa verificar de variações nas práticas pedagógicas que se aplicavam. Embora o convívio com os pais não fosse tão frequentemente tomado como perverso, quiçá uma das primeiras grandes inovações nas propostas de educação para o indígena, o isolamento da criança do mundo de seus antecessores permanecia como uma das práticas preconizadas. José Bonifácio acredita que, sem a intervenção do recém-formado império brasileiro, as crianças guaranis não se tornariam mais capazes do que qualquer marreco:

Newton se nascera entre os Guaranis seria mais hum bipede que pezara sobre a superfície da terra; mas hum Guarani criado por Newton tal vez que ocupasse o seu lugar. (SILVA, 1963, p. 53)

O Barão de Congonhas do Campo (1826 apud NAUd, 1971, p. 329) propõe que se separem os filhos de seus pais para que estes não comuniquem a aqueles suas "paixoens dominantes e afectos ao roubo", considerando as aldeias não mais que "viveiros para tirar-lhes alguns filhos, que venhão depois a ser Cidadãos mais uteis que seos Pais". Na elaboração de um projeto de um colégio destinado à instrução da mocidade indígena, na província de Minas Gerais, em 1832, propôs-se que fossem recolhidos os índios logo que "tocarem a idade de cinco annos completos, e emquanto não tiverem mais de doze, e serão nelle conservados segundo os estatutos, até que tenham recebido o grao de instrucção conveniente" (José Lino Coutinho, Ministro e Secretário de Estado dos Negócios do Império, 1832 apud CunHA, 1992, p. 154).

Esse isolamento, à semelhança da proposta jesuítica, decorria, ao que parece, da dificuldade de se concorrer na educação 
que se lhes propunha, com a educação tradicional de seus pais. É significativo o comentário que faz Anthonio Oliveira, em 1827, a respeito dos índios caiapós:

São naturalmente preguiçozos, e por mais deligencia que eu tenha feito, não tenho podido ate o prezente conseguir o milhor resultado, quanto a sua cathequização por isso que alguns Indios ja velhos, e que tem estado nas Aldeias existentes perto da cidade de Goyaz, tem emigrado para as Aldeias de cá, e aconselhão sempre mal aos Indios moços. (NAUd, 1971, p.307)

A ideia do Barão de Congonhas do Campo (1826 apud Naud, 1971, p. 329) de que "raras vezes, ou nunca, se civilisão, quando são tirados das brenhas já adultos" pressupõe o que em 1857 é reafirmado por Luiz Ferraz: uma idade de mais "facilmente adquirirem novos costumes" (apud CunHA, 1992, p. 244-245). A educação, ou a civilização, deveria, então, ser realizada com indivíduos pequenos, cujo contato com a sociedade tradicional não lhes tivesse imprimido outros hábitos.

Os hábitos arraigados parecem ser tomados, então, como intrínsecos do índio adulto, o qual, fora da sujeição civilizadora das autoridades civis e eclesiásticas, necessariamente retomaria sua vida tribal. Antonio Besford, em 1826, acredita que "a pequena civilização que tinham adquirido debaixo dos Directorios se acha de todo corrompida com a relaxação, ou quase aniquilação, em que nestes ultimos tempos tem ficado esses mesmos Directorios" (NAUd, 1971, p. 396); José Ferrão, em 1827, diz que os índios, desde o descobrimento, "mudarão inteiramente de economia animal, e logo depois passarão a corrompidos selvagens, de que outra vez sahirão" (NAUd, 1971, p. 330).

Paralela, entretanto, à ideia de que a transformação do indígena só se poderia obter mediante o que, já em 1808, o Príncipe 
define como "uma escola severa" (CunHA, 1992, p. 62), havia uma corrente que acreditava nessa transformação pelos processos informais do convívio diário. O visconde de Caravellas, por exemplo, imaginou que os Botocudos se iriam civilizando, com mais facilidade, pelo trato quotidiano com os índios mansos (1826 apud NaUd, 1971, p. 299); Ignacio Vasconcellos, mesmo ano, propunha que se distribuíssem os casais pelas cidades, tão logo saíssem dos matos, pois, segundo ele, "o tracto urbano mais depressa os civilizará" (p. 298); Alexandre Machado, também em 1826, considerava que não havia "outra providencia se não fazel-os entrar na massa comum de todos os habitantes" (NAUD, 1971, p. 305) para a civilização eficaz dos índios das aldeias.

Também complementando essas práticas transformadoras, havia uma formação profissional que se oficializava pela introdução de ofícios profissionalizantes em escolas que se estabeleciam (José Coutinho, 1832 apud CunHa, 1992, p. 154). José Bonifácio, em 1923, sugeria o estabelecimento de oficina de artes mecânicas (SILva, 1963, p. 172); Manoel Faria, provavelmente na segunda metade do segundo decênio do século XIX (NAUd, 1971, p. 334), queria que "se tirasse de suas familias rapazes para irem as Praças aprenderem officios, e artes"; Eduardo Machado, em 1854, pensava em obrigar os filhos dos índios que residissem nas colônias "a aprender, nas officinas fundadas pelo Governo, officios mechanicos" (Cunha, 1992, p. 228); Diogo de Albuquerque, em 1870, queria que o ensino compreendesse, além da doutrina cristã e das primeiras letras, "os officios mecanicos, especialmente ferreiro e carpinteiro com applicação especial a construcão naval, bem como a pratica da agricultura" (CunHa, 1992, p. 270).

Muito semelhantemente às primeiras tentativas de educação para o indígena, pouco, ou nada, se via do interesse do próprio educando pesar no estabelecimento de conteúdos e técnicas de ensino. A transformação do índio continuava, aos olhos de seus 
agentes, imperativa por ela própria. Aos índios cabia aceitá-la. Sua opinião só seria considerada nesse sentido. José Bonifácio propôs que se ensinasse ler, escrever e contar aos adultos, quando estes se dispusessem a adquirir essa instrução (SILVA, 1963, p. 177); Diogo de Albuquerque também reportou-se ao interesse adulto nessa aprendizagem, sugerindo que os que mostrassem aptidão para aprender frequentassem o Collegio Isabel, no Vale do Araguaya (1870 apud CunHa, 1992, p. 271).

São raras as vezes em que se indicam os próprios índios como agentes de sua transformação. $\mathrm{O}$ visconde de Caravellas, em 1826, afirmou:

Sendo certo que a civilização de similhantes selvagens he obra do tempo, acho sedo para os fazer conter em hum lugar: he necessario por ora ir com a vontade delles. (NAUD, 1971, p. 299)

Joaquim Oliveira, a propósito de questão bastante semelhante, fez considerações parecidas:

[...] a localidade do seu Aldeamento, deve a arbítrio e escôlha dos mesmos Indios; paréce injuztiça que ao dôno da caza, se determine lugar para sua estáda. (NAUD, 1971, p. 307)

Quanto ao uso da língua materna, ela volta a ser predominantemente preconizada para a educação. José Bonifácio, como já se viu, lembra os jesuítas nesse procedimento; o tenente coronel Marliére, em 1826, o acompanha, tomando-o dessa maneira:

a chave da civilisação era o estudo da lingua dos Indios [...] hum Padre Pontes de S. Paulo, hum pobre idiota cujo unico talento era fallar bem a lingua dos Indios entre quem nasceo, e assim mesmo fez muitos serviços nas Aldeas. (p. 310) 
O cônego Barboza, já em 1839, afirmou ser "de absoluta necessidade que se faça aprender a língua Brasílica aos que tem de missionar aos nossos índios" (1940, p. 15), retomando o argumento do dom das línguas que o espírito santo infundiu nos apóstolos.

Entretanto, uma outra corrente, pouco representada na documentação que se analisou, segue a proposta do Diretório de 1757, de ensino na língua portuguesa, permanecendo no pensamento administrativo, pelo menos, no de Caetano Gama, em 1826, sugerindo aos missionários ensinarem a doutrina cristã a meninos e meninas, falando sempre na língua portuguesa (NAUD, 1971, p. 304).

\subsection{O SPI e a Sociedade para a civilização dos índios}

O início do século XX assistiu a uma pequena mudança nos rumos das propostas oficiais de educação para o indígena. As ideias civilizatórias e evangelizadoras, ainda que não desaparecessem, viriam ser complementadas por uma nova proposta, sob o rótulo que acabou por constituir-se como "proteção" (Decreto 8072 de 20/06/1910 apud Oliveira, 1947, p. 89). A ideia, porém, não foi um consenso em toda a recém-fundada república. José Mauro Gagliardi discrimina três tendências políticas distintas: a primeira "aconselhava o extermínio dos índios bravos que ousassem barrar a expansão da economia nacional"; a segunda afirmava "que a incorporação do índio à sociedade somente seria possível através da catequese desenvolvida pela Igreja Católica" e a terceira preconizava "que a única alternativa para a população indígena era a criação de um órgão, orientado por princípios leigos, que lhe assegurasse a proteção da lei e o direito de posse das terras que habitava" (1989, p. 134).

Ao se considerar que a primeira proposta - a de extermínio — não pode se realizar como uma tentativa de transformação das comunidades indígenas, somente as duas propostas seguintes - a 
da catequese pela igreja católica e a da criação de um órgão leigo de proteção - atentam para a questão da transformação do índio.

A proposta de se retomar a educação jesuítica dos séculos XVI e XVII como modelo apareceu claramente explicitada na Revista da Sociedade de Ethnographia e Civilização dos Indios, apresentada por Theodoro Sampaio. Além de afirmar que a sociedade "vem hoje empenhar esforços em prol da restauração das missões, dos aldeamentos dos índios sob a direcção das Ordens Religiosas, as únicas capazes desse abnegado sacrifício pelas raças inferiores", nessa introdução, Sampaio (1901, p. VIII) recomenda o uso da língua materna nesse propósito, dando Anchieta e Figueira como exemplos e preconiza o estudo e o ensino dessas línguas nos seminários e nos cursos regulares.

$\mathrm{Na}$ ata da primeira sessão iniciativa dessa Sociedade, estabeleceram-se, entre outras, duas comissões: a de "linguística e philologia [que] tem por fim ativar o estudo das línguas indígenas da América do Sul, especialmente da língua tupi e das que se falam neste Estado" (São Paulo) e a de "catechese [que] tem por fim activar o estudo dos meios de promover a catechese e a civilisação dos indios deste Estado". Muito embora não tenham sido indicadas quaisquer técnicas para a realização dos trabalhos dessa última comissão, o uso da língua materna, a se guiar pelas palavras de Theodoro Sampaio e pelo modelo que se propunha seguir, poderia ter sido recomendado.

Ihering (1911), que havia dois anos alinhara-se à proposta de extermínio, retoma o argumento da educação missionária para a transformação do índio (p. 133). Assim, repete a ideia do uso da "língua dos índios" como instrumento eficaz para esse processo (1911, p. 133), considera a vida indígena independente como um obstáculo a qualquer tentativa de transformação (p. 118) e tem como objetivo a completa assimilação do índio ao resto da população rural, por meio de processos educacionais continuados (1911, 
p. 118). Entretanto, segundo ele, os resultados só poderiam ser observados após algumas gerações, restabelecendo, de certa maneira, a dúvida quanto à eficácia da educação de adultos.

Nesse caso, a proposta de extermínio de Ihering parece ter sido revisada por ele próprio, pelo menos o cientista assim propalava. O estímulo para a assimilação substituía o extermínio e o agente daquele voltava a ser o missionário. Entretanto, Ihering afirmou que tanto a "catequese" quanto o "ensino religioso" deveriam ser optativos para os índios independentes (1911, p. 133), trazendo à tona o fato de que o interesse dos índios devesse ser considerado. Aos demais índios, a moral cristã seria núcleo indispensável do ensino (1911, p. 133) .

Novamente, a educação jesuítica missionária era tomada como padrão. Os aldeamentos seriam estimulados pela política oficial, ou parte dela, o uso da língua nativa seria o veículo próprio de comunicação entre os grupos e os agentes transformadores seriam os religiosos - católicos.

Com o estabelecimento em 1910 do Serviço de Proteção aos Índios, a outra tendência apareceu oficialmente manifesta. No seu regulamento, entretanto, havia, quanto aos meios destinados a isso, poucas diferenças em relação a outra tendência. $\mathrm{O}$ uso da língua nativa é preconizado no artigo 18, que estabeleceu prêmio para os funcionários que "adquirirem perfeito conhecimento da língua geral e dos seus dialetos" (GAGLiARdi, 1989, p. 310). O estabelecimento de "escolas para o ensino primário e aulas de música" é referido no artigo 15 e a transferência de "instituição destinada a educação dos índios para o governo federal”, no artigo 18. Nesse caso, é de se supor que o ensino preconizado ocorresse em estabelecimentos próprios para isso.

Assim, como a outra proposta não deixou claro como as ordens religiosas deveriam realizar a catequese, também não se deixou claro para o novo órgão oficial que se criara como deveria 
ser a educação para o indígena. O material linguístico coletado pela Comissão Telegráfica (bem como os estudos desenvolvidos pelos membros da Sociedade de Ethnographia e Civilisação dos Índios) eram vocabulários, esboços gramaticais (e filológicos). A se tomar por base as línguas que já haviam sido estudadas até aquele momento, além da guarani, nenhuma outra poderia ter sido utilizada para as práticas alfabetizatórias sugeridas, em virtude de esse material ser escasso e ainda incipiente. A língua portuguesa era, então, novamente o veículo de contato com a escrita para esses grupos.

A oficialização da educação primária nas aldeias foi uma das principais inovações do início do século. O ensino formal era, até então, completamente associado aos demais comportamentos da tradição europeia. A "escola" na aldeia fora uma tentativa da educação jesuítica nos primeiros momentos da colônia. Porém, quando de sua realização, não se poderia pensar em outras possibilidades: os grandes aglomerados populacionais eram somente as aldeias indígenas. Tão logo se formassem as vilas portuguesas, as "escolas" estabeleciam-se nelas.

Essa oficialização, entretanto, não tinha como propósito produzir um isolamento tão radical das práticas pedagógicas. O que se pretendia era levar a civilização para o índio, numa tentativa de se provocar a ruralização das aldeias. $\mathrm{O}$ artigo 11 do regulamento determinou que se despertasse a atenção dos índios "para os meios de modificar a construção de suas habitações”. Barbosa (1926) afirmou que "pela implantação de um ensino tão activo, quanto possível, de arte, officios e primeiras letras" seria possível proporcionar aos índios uma melhoria das condições de vida e "aplainar-lhes o caminho nos progressos de ordem moral" (p. 10-11). Rondon (1945 apud Oliveira, 1947) esperava que "sua evolução se [operasse] naturalmente e pelos contatos pacíficos que êle [pudesse] ter com os civilizados" (p. 27). 
Outra novidade fundamental na educação para o indígena sugerida na criação do SPI era, de fato, a recuperação de uma ideia apenas referida no século XIX. A manutenção dos costumes tradicionais do grupo, de par com as tentativas de provocar-lhes, com "brandura" e consentimento do chefe, as transformações desejadas, até que os próprios índios assumissem, naturalmente, sua nova condição, essa manutenção trazia implícita a convivência entre jovens e velhos, reportando-se textualmente ao respeito a hábitos e instituições indígenas. Entretanto, o artigo 4 do regulamento sugeria uma cuidadosa intervenção do Estado no sentido de promover a integração do índio à sociedade republicana. Além das intervenções já referidas, o artigo 16 estabeleceu como um dos objetivos do SPI “ministrar, sem caráter obrigatório, instrução primária e profissional, aos filhos dos índios, consultando sempre a vontade dos pais" (GAGLIARDI, 1989, p. 307).

Embora não seja possível verificar no que consistiam exatamente as diferenças nos meios de se provocar a transformação do indígena, Stauffer (1959) considerou que a ausência de missionários religiosos como agentes transformadores dos índios era uma das diferenças marcantes do programa do SPI:

\footnotetext{
o programa leigo de instrução dos índios, previsto nas diretrizes do S.P.I., marcou um desvio radical da secular prática brasileira de encarregar o clero de tôda a responsabilidade e supervisão de seu bem estar e de sua educação. (p. 73)
}

Entretanto, se a presença missionária deixava de ser obrigatória, o ensino religioso não fora descartado. Barbosa (1919), ainda que não considerasse a catequese religiosa como preocupação do SPI, previu a sua realização; ele afirma que o regime republicano "sem se preocupar com saber quem quererá tomar para si a tarefa de conquistar a adezão das almas a alguma das doutrinas que entre si disputam o governo dos espíritos, limita-se a agir no sentido de 
amparar os direitos de todos" (p. 31-32), deixando claro que ao SPI não caberia essa tarefa, mas que ela poderia ser realizada. A crítica que fazia ao trabalho religioso não se dirigia para a questão da catequese ou da evangelização, mas, sobretudo, à duvidosa atuação dos padres quanto às práticas transformadoras que deveriam realizar sobre os índios.

\begin{abstract}
Nunca ensinaram ou educaram nenhum menino indigena, nunca promoveram o casamento catholico de nenhum indio e, apesar de se encontrarem perto os Jaricunas e os Ingaricós, que, sendo pacificos e de boa indole, conservam-se, todavia, na maior parte inteiramente arredios; e, apesar de não muito longe ficarem os Porocotós, os Manhodons e os Tapiocas, de quem pouco se sabe, mas de quem se sabe que são igualmente inofensivos e que, atrahidos pelas vantagens da Guyana Ingleza para ella frequentemente se transferem, apesar de tudo isto, nunca fizeram os padres o menor esforço, a menor viagem, em procura ou em beneficio desses selvagens. (BARbosa, 1919, p. 83)
\end{abstract}

Ainda segundo Horta Barbosa, a educação para o indígena, realizada "pelas povoações e postos indígenas, onde se os localisa e se lhes dá o ensino rural e uma instrucção condizente á sua situação" (p. 117), apresentava resultados bastante favoráveis.

Alguns anos depois, no Regulamento de 1936, tais propósitos eram manifestamente assumidos. Assim, o item "b" do artigo $1^{\circ}$ desse regulamento definia como objetivo do SPI:

b) pôr em execução medidas e ensinamentos para a nacionalização dos selvícolas, com o objetivo de sua incorporação à sociedade brasileira. (Decreto n 736 de 6/4/1936 apud Oliveira, 1947, p. 148)

Para atingir esses objetivos, a escola primária e profissional apresentava-se como um dos meios, lado aos exercícios físicos 
militares a educação moral e cívica e os ensinos de aplicação agrícola ou pecuária.

Em 1942, o Decreto 652 que estabelecia um novo Regulamento para o SPI acrescentou a determinação de se "atrair o índio e fixá-lo pela cultura sistemática da terra e estabelecimento das indústrias rudimentares mais necessárias". Novamente, combatia-se o nomadismo indígena, procurando "incentivar a construção de casas", de forma a integrar os índios na sociedade rural. Dessa maneira, se a proposta revista de Ihering preconizava a transformação do índio bravo em índio manso e preconizava a transformação do índio manso em população agrícola totalmente integrada à sociedade nacional, o SPI tinha os mesmos objetivos, realizáveis a partir da "proteção". Ressaltam apenas as diferenças referentes aos agentes dessa integração que, para a Sociedade de Ethnographia $e$ Civilisação dos Indios e para Ihering, deveriam ser as missões religiosas, e para o SPI poderiam ser as mesmas missões para o trato espiritual e o Estado para a educação formal e profissional. Entretanto, a educação formal nas próprias aldeias indígenas, preconizada diversas vezes pela proposta do SPI, não se manifestou claramente pela outra tendência, ainda que não fosse outra a atuação dos padres nas missões que estabeleciam.

\subsection{FUNAI e SIL}

A partir da segunda metade do século XX, uma nova instituição religiosa passa a contribuir nos processos educacionais a que se submeteram os índios no Brasil. Em 1956, quando se firmou um primeiro convênio do Summer Institute of Linguistics com o Museu Nacional, em seguida, com a Universidade de Brasília, e, posteriormente, com a Unicamp, a tarefa de transformar oficialmente o índio, conforme padrões pré-estabelecidos a partir 
da cultura europeia, reassumiu seu caráter religioso, mesmo por uma instituição que ainda não se secularizara no Brasil. Desde 1919, os protestantes eram tomados com simpatia até pelos membros mais contrários à intervenção religiosa dos Salesianos entre os índios no Brasil.

Nas proximidades do Posto Indígena do Bananal (Matto Grosso) estabeleceu-se ha longos annos, em terras e casas de sua propriedade, uma missão protestante de catechese. Grande numero de indios frequentam o culto desses padres e ha entre elles um certo numero que se crê sinceramente convertido ao protestantismo. A Inspectoria do Serviço de Protecção aos Indios, cumprindo seu dever, dá-lhes inteira liberdade de assistirem, como quizerem a tais actos velando apenas pela ordem e tendo o cuidado de não deixar que a pretexto de religião sejam elles explorados - cousa que aliás nunca foi tentada por esse dignos missionários protestantes. (BARbosa, 1919, p. 9-10)

Após uma primeira atuação de caráter eminentemente científico, o Summer Institute of Linguistics passou a atuar, em convênio com a Funai, na educação em área indígena. Ferreira (1992, p. 170) considerou que esse convênio visava a "instaurar uma política indigenista internacionalmente aceita e cientificamente fundamentada, suprindo as deficiências do SPI no que diz respeito à desqualificação de seu quadro técnico". ${ }^{1}$ Nos termos desse primeiro acordo, firmado em 1969 (apud LeITE, 1981, p. 62), rezava o seguinte:

A ação do Instituto no campo da alfabetização compreenderá:

a) preparação de cartilhas em idiomas indígenas;

b) elaboração de cartilhas bilíngues (língua indígena-português) visando ao aprendizado do idioma nacional;

1 Quanto à atuação do Summer no Brasil, cf. Wilson, 1969, Leite, 1981, Seeger, 1981, Oliveira, 1981, Franchetto, 1981, Cadernos do Terceiro Mundo, 1982 e Barros, 1993. 


\section{Os Índios e a Alfabetização}

c) preparação de livros de leitura, registros de literatura oral e tradução de textos bíblicos e outros de alto valor cívico e moral para os idiomas indígenas.

Sem apresentar novidades em relação às propostas de ensino missionário, senão quanto à língua a ser utilizada no processo alfabetizatório, a ação descrita reproduzia praticamente todos os passos das técnicas jesuíticas do primeiro século da colonização, isto é, alfabetização e leitura de textos de caráter religioso. A novidade da alfabetização em língua materna, entretanto, merece ser tomada um pouco mais detidamente.

Jaime Wilson, membro do Summer, justificou o ensino da escrita e da leitura na língua materna do grupo indígena pela facilidade e rapidez que isso envolve:

é só ver a facilidade com que um índio aprende a ler quando se trata de sua própria língua materna, para ficar convencido de que não existe outro caminho para introduzir o silvícola no mundo da escrita. (1969, p. 172)

O uso da língua materna documentada graficamente, entretanto, não era um fim em si mesmo. Segundo, ainda, Wilson (1969), o uso da língua tribal na educação não era mais do que um passo no caminho para a língua nacional, pois isso viria com uma cartilha de transição que apresentava o Português no quadro da língua tribal.

Nesse caso, explicitava-se claramente os itens "a)" e "b)" do acordo citado. Pressupunha-se que o índio apreenderia as técnicas de escrita em sua língua tradicional e, em seguida, retomá-las-ia para a língua portuguesa. Essa passagem ocorreu bem descrita por Kindell e Jones (1978, p. 44), quando apresentaram a programação aplicada ao $1^{\circ}$ Curso de Monitores Kaingang: 


\begin{tabular}{|c|c|c|c|c|}
\hline & $1^{\circ}$ Semestre & $2^{\circ}$ Semestre & $3^{\circ}$ Semestre & $4^{\circ}$ Semestre \\
\hline \multirow{2}{*}{$\begin{array}{l}\text { Instrução na } \\
\text { língua materna }\end{array}$} & $\begin{array}{l}\text { Pré-leitura } \\
\text { Pré-escrita }\end{array}$ & $\begin{array}{l}\text { Alfabetização na } \\
\text { língua materna }\end{array}$ & $\begin{array}{l}\text { Alfabetização na } \\
\text { língua materna }\end{array}$ & $\begin{array}{l}\text { Alfabetização na } \\
\text { língua materna }\end{array}$ \\
\hline & Pré-cálculo & Matemática & Matemática & Matemática \\
\hline \multirow{2}{*}{$\begin{array}{l}\text { Instrução em } \\
\text { Português }\end{array}$} & $\begin{array}{l}\text { Estudos } \\
\text { Sociais }\end{array}$ & $\begin{array}{l}\text { Estudos } \\
\text { Sociais }\end{array}$ & $\begin{array}{l}\text { Estudos } \\
\text { Sociais }\end{array}$ & $\begin{array}{l}\text { Estudos } \\
\text { Sociais }\end{array}$ \\
\hline & $\begin{array}{c}\text { Português } \\
\text { Oral }\end{array}$ & $\begin{array}{l}\text { Português } \\
\text { Oral }\end{array}$ & $\begin{array}{c}\text { Português } \\
\text { Oral }\end{array}$ & $\begin{array}{l}\text { Alfabetização } \\
\text { em português } \\
\text { (transição) }\end{array}$ \\
\hline
\end{tabular}

Verifica-se que, após um ano e meio de alfabetização na língua materna, iniciava-se o ensino de leitura e escritura na língua portuguesa. Alguns anos antes, Newman (1975) descrevera esse processo, salientando que a alfabetização na língua materna e a aprendizagem oral do português, simultaneamente, forneceriam ao educando "o respeito e o orgulho que sua língua e cultura merecem":

Assim, ele sente orgulho de sua herança indígena, e com esta base ele pode desenvolver o mesmo amor para com sua herança como brasileiro e participante na vida nacional. (p. 69)

A definição da grafia e o conhecimento da língua, entretanto, eram etapas que ocorreriam previamente a todo esse processo. Bridgeman disse a esse respeito:

No caso de utilizar a língua minoritária no ensino, ainda é necessário decidir, muitas vezes, entre vários dialetos da língua, a fim de elaborar uma só ortografia e material didático que atenda às necessidades do grupo inteiro. (s.d., p. 106)

O estabelecimento de critérios externos para a seleção do dialeto a ser considerado para a escrita na língua materna indígena denuncia a manutenção da tendência de deixar os índios à margem 
de sua própria transformação. Esse fato apareceu ainda mais claramente quando a Portaria 75/N da Funai, de 7/7/72, resolveu que:

3. A grafia das línguas indígenas, para textos de consumo dos grupos tribais, deve ser a mais aproximada possível do português;

4. Deve-se adotar como norma geral, na grafia das línguas indígenas, o princípio lógico de representação de um fonema por um único símbolo;

5. O Departamento Geral de Assistência [...] fica incumbido de reunir colaboradores técnicos, examinar e propor normas para a grafia das publicações em língua indígena. (apud Newman, 1973, p. 21)

Mesmo em traços específicos da cultura do grupo, tais como a definição de uma escrita para sua língua tradicional, a transformação do índio ocorreria por determinação das instituições agentes desse processo. Para a grafia Xavante, por exemplo, Hall (1979) estabeleceu uma adaptação do alfabeto romano, a partir de análise contrastiva com o seu uso na língua portuguesa. Quase vinte anos depois, Ekdahl e Butler (1994) mantiveram esse princípio na elaboração do que chamaram "alfabeto terena", apenas deixando ao grupo a decisão para alguns casos mais polêmicos, como o uso da letra "k" em lugar de "c/qu" (p. 1-2).

Esse caráter transformador foi descrito por James Wilson, quando previu o desaparecimento dos índios como um todo:

A ideia da vida romântica, idílica, do índio selvagem já não tem mais significado. O índio encontra-se hoje face a face com o dilema mortal: ou ele se adapta ao convívio com nossa civilização ou morre sôbre (sic) a pressão insuportável do século XX. (1969, p. 171)

Quanto a essa adaptação do índio, Newman a descreveu da seguinte maneira: 
O índio brasileiro é a motivação e preocupação desta apresentação. Ele representa culturas e línguas diferentes da maioria dos brasileiros, merecendo todo apoio necessário para que possa realizar sua potencialidade pessoal no campo que escolherá através de uma educação integral [...]. É esta barreira de comunicação que tem que ser rompida, emancipando o indígena na sua marcha de pensamento e desenvolvimento. (1973, p. 1, grifos do autor)

A adaptação do índio à "nossa civilização", pois, preconizava uma "educação integral" que se imaginava permitir-lhe "desenvolver seu próprio pensamento" e "realizar sua potencialidade pessoal", isto é, o índio e suas formas de pensamento e de realização pessoal eram tomados como se fossem insuficientes para atuarem por si só, necessitando do apoio necessário das formas de educação conhecidas pelas instituições que se propunham a realizar essa tarefa complementar da cultura tradicional indígena. A educação seria necessariamente exógena, definida a partir dos padrões próprios das instituições envolvidas nesse processo. O convênio de 1983, com a Funai, determinou que o Summer Institute of Linguistics deveria comprometer-se a:

3. Prestar aos índios dos grupos mencionados, assistência linguística e educacional, de saúde e comunitária. (1983, p. 4)

Embora o convênio não definisse o que entendia por "assistência linguística" - possivelmente o estabelecimento de uma grafia para as línguas tradicionais desses grupos, bem como a realização de traduções ou auxílio em traduções, ou versões, de textos de natureza diversa - , pode-se crer que esse auxílio teria sido sempre no sentido de determinar as diretrizes do contato do grupo com a sociedade nacional brasileira. 
À novidade a que já se chamou a atenção - a alfabetização em língua materna e a leitura de textos, ainda que religiosos traduzidos para essa mesma língua - , pode-se acrescentar duas outras: a elaboração de materiais de leitura e a formação de monitores índios para a educação.

$\mathrm{Na}$ introdução à bibliografia para divulgação dos trabalhos do Summer no Brasil, justificou-se o uso da língua tradicional escrita dentro de uma comunidade indígena pelo fato de ela poder ser tomada como "veículo de transmissão e preservação dos costumes e mitos, bem como ampliação dos conhecimentos gerais" (1978, p. 8). Kindell e Jones propuseram que "o primeiro passo na criação de uma comunidade alfabetizada [fosse] o desenvolvimento de uma literatura vernácula, embora esta não seja muito variada no começo" (1978, p. 10). Para ambas as finalidades, "preservação de costumes e mitos" e "desenvolvimento de uma literatura vernácula", a proposta de educação bilíngue e bicultural do Summer envolveria a formação de escritores indígenas.

Numa comunidade recém-alfabetizada, as pessoas não só lêem como também escrevem. A maioria dos recém-alfabetizados deve escrever cartas, contribuir para uma revista ou boletim de notícias de seu grupo, e produzir narrativas, poesias, autobiografias, relatórios de viagem, etc., para serem lidos por outros. (KINDELL; JonES, 1978, p. 10)

No próprio convênio com a Funai, essa atividade já aparecia prevista como compromisso do Summer:

2. estimular os grupos a prepararem, eles próprios, livros de leitura, tais como lendas, mitos e histórias sobre a vivência indígena, nos idiomas específicos acompanhados da respectiva tradução em português para serem utilizados como textos de leitura. (1983, p. 5) 
É de se salientar que tais textos foram realizados em número de 428, distribuídos em 27 línguas diferentes, e que 58 cartilhas, em 20 línguas diferentes, também foram realizadas, no período compreendido entre os anos 1973 e 1980 (Bibliografia, 1981). Tal fato indica que os programas de educação bilíngue-bicultural do Summer foram efetivamente levados às áreas descritas no convênio de 1983.

Quanto ao ensino por monitores indígenas, como intermediários no processo transformador, é possível verificar tratar-se de restauração das tentativas nesse sentido, realizadas por Lancaster e Bell, na passagem do século XVII para o XVIII. Manacorda descreveu-as:

\begin{abstract}
Nos anos da Revolução Francesa vinha-se afirmando na Inglaterra uma nova iniciativa educacional promovida por particulares: o chamado "ensino mútuo" ou "monitorial", no qual adolescentes instruídos diretamente pelo mestre, atuando com variedade de tarefas como auxiliares ou monitores, ensinam por sua vez outros adolescentes, supervisionando a conduta deles e administrando os materiais didáticos. (1992, p. 256)
\end{abstract}

A educação indígena levada a cabo pelo Summer permaneceu como uma projeção das formas básicas da educação europeia sobre os interesses indígenas na aquisição da língua escrita. Pode-se notar que a alfabetização continuava acompanhada de tentativas de transformação, as quais ultrapassavam os limites do processo alfabetizatório. Muito embora não se possa encontrar expressa a ideia de "salvação" ou de "civilização", o propósito integracionista aparece explícito. Kindell e Jones definiram a educação bilíngue-bicultural:

é um programa educacional em que duas línguas são usadas como meios de instrução, e duas culturas, a indígena e a nacional, são expostas e comparadas, a fim de possibilitar 


\section{Os Índios e a Alfabetização}

aos indígenas uma integração conscientizada e positiva. (1978, p. 7)

Newman, por sua vez, considerou:

a educação bilíngue não leva o indígena a deixar de sê-lo, mas, ao contrário, arma-o com a possibilidade de enriquecer a sua cultura através de uma formação mais ampla, e por sua vez, contribuindo para a vida nacional. (1973, p. 9)

E Bridgeman, finalmente, apôs a "alfabetização de um povo ágrafo" a um povo "cuja língua está na primeira fase de ter uma forma escrita" (s.d., p. 103).

Nos três depoimentos, é possível destacar "integração consciente e positiva", "contribuindo para a vida nacional" e "primeira fase de ter uma forma escrita". Ainda que cada qual tome o problema por um ângulo diferente, as três posições convergiam para a transformação do índio no sentido de igualar-se aos padrões culturais conhecidos, quais sejam os de cidadãos brasileiros e letrados. A ideia de que um "povo ágrafo" é um povo que está na marcha do desenvolvimento para tornar-se alfabetizado complementava as ideias de integração na sociedade nacional e de sua contribuição para ela, como brasileiro, identidade que se superporia à sua própria.

A preservação da diferença, por sua vez, foi tomada como um dos objetivos desse processo. Na passagem já citada da bibliografia do Summer (1973, p. 8), a utilização da escrita como forma de documentação e transmissão de costumes pressupunha a transformação desses costumes e de sua própria forma de documentação e transmissão. A substituição da cultura tradicional por uma transformação linguística da maioria de seus traços, tais como mitos cristalizados graficamente, indica um resultado bastante diferente dos objetivos propostos de preservação da cultura indígena. 
Novamente, a educação era realizada a partir de motivos outros do que os interesses indígenas, apesar de ambos tocarem-se em muitos pontos, como sempre, da aquisição da escrita. O processo educacional ainda era conduzido como uma necessidade da instituição educadora, quer fosse o Summer Institute of Linguistics, quer fosse a própria Funai. O índio permaneceria como objeto, marginal às decisões que lhe diziam respeito.

\subsection{A educação leiga}

Desde o início do último quartel do século $\mathrm{XX}$, até os nossos dias e, provavelmente, para além deles, diversificaram-se as iniciativas para a educação indígena. Nesse período, coevas com as atividades do Summer Institute of Linguistics, membros de muitas instituições, acadêmicas ou não - alguns, inclusive, ligados a instituições religiosas, protestantes e católicas -, tomaram para si também a responsabilidade desse processo. É possível verificar-se o crescente número de antropólogos, pedagogos, linguistas, matemáticos, dentre outros, envolvidos nas questões dessa educação.

A alfabetização e o ensino da matemática tornaram-se os temas principais desses debates. Sobretudo alguns pontos da alfabetização, como a questão da língua em que ela deveria ocorrer, da forma de se conceber o material didático, da temática a ser explorada nos livros de leitura, da maneira de se formar monitores índios para o ensino sistemático dentro das aldeias, e outros, todos eles passaram a constar de muitas reuniões e encontros realizados para uma constante troca de informações sobre os trabalhos educacionais que ocorriam em diversas partes do país, visando sempre ao aperfeiçoamento dessa prática. Indiscutivelmente, tratou-se de um período fertilíssimo nesse sentido. 
Muito embora não se disponha de estudos sistematizados sobre a validade da interferência da escola nos processos de manutenção da identidade étnica de grupos indígenas frente à sociedade nacional brasileira - bem como do papel efetivamente realizado pelos próprios grupos nesses processos - essa era a ideia que orientava o estabelecimento da maior parte das escolas em áreas indígenas ou outro local a que os índios tivessem acesso. Leite et al assim definiram essa "educação para indígenas":

Trata-se, a nosso ver, de um amplo processo que se dá formalmente numa escola em aldeia indígena, cuja função consiste, de um lado, em fornecer, devido a atual conjuntura em que se insere a questão indígena mais geral, o instrumental necesssário para que as populações indígenas passem a entender melhor a sociedade envolvente, de modo a poderem optar pelo seu grau de participação na sociedade nacional e fazer valer, sempre que necessário, seus direitos já adquiridos e constantes em lei. Por outro lado, concomitantemente a esse processo de decifração do mundo dos brancos, é necessário que essa educação vise a resgatar o passado indígena e permita a permanência e a incorporação, de maneira criativa, do saber científico desses povos: o seu conhecimento do mundo, seu próprio modo de contar e medir, o seu domínio da natureza. Só assim ter-se-á, de fato, um processo educacional bi-cultural. (1985, p. 1-2)

Dessa longa definição é possível destacar alguns pontos que merecem ser analisados mais atentamente: a educação para indígenas sugerida deveria (i) instrumentalizar os índios para que pudessem optar pelo seu grau de participação na sociedade nacional, (ii) resgatar a cultura tradicional do grupo e (iii) permitir a permanência e a incorporação do saber científico desses povos.

O primeiro item já aparece como indicador de que se imaginava a escola um veículo capaz de suprir o grupo com as 
informações necessárias para realizar tal opção. De certa maneira, pressupunha a escola como uma forma complementar para essa cultura. Essa mesma ideia já aparecera na afirmação de Oliveira e Diniz (1981):

O seu sentido maior [da escola] era [...] de servir como apoio e instrumento de reflexão para a conscientização das relações com o mundo dos brancos, participando diretamente do momento vivido da comunidade. (p. 34)

Igualmente, Lea (1981, p. 65) afirmara que "os índios precisam de informações sobre o mundo dos caraíbas". Mais recentemente, Monserrat (1991) reafirmou essa função da escola:

Queremos, sim, uma escola Parakanã. E esta, eles terão de descobri-la, não sozinhos, é certo, que nenhum povo pode prescindir do auxílio de outros, sobretudo quando esses outros detêm conhecimentos e tecnologias diferentes e por vezes valiosas, como é o caso, mas basicamente com o seu suor, suas dúvidas e suas fantasias. (JorNAL Do BRASIL, 15 jul. 1991)

De outro ponto de vista, mas tomando a cultura tradicional dos grupos pelo mesmo viés de sua insuficiência, o bispo Raimundo Damasceno Assis, secretário-geral do Conselho Episcopal Latino-Americano (Celam), ao comentar sobre o tema da conversão do índio, que seria discutido na $4^{\text {a }}$ Conferência da Celam, afirmou:

Temos de assimilar o que é bom nas culturas nativas, mas corrigir suas imperfeições. (O Estado de São Paulo, 2 mai. 1992)

Assim, as posturas irradiavam-se a partir da mesma consideração, qual seja, a de que, após o contato, os índios não 
puderam mais suster a si mesmos, necessitando, pois, de auxílio externo. A esse respeito é interessante verificar, no mesmo artigo, que o bispo ainda oferece exemplo dessa "imperfeição", ao afirmar que "precisamos anunciar o evangelho para que esses povos compreendam que a monogamia é a expressão do amor" (O Estado de São Paulo, 2 mai. 1992). O processo para isso, entretanto, deveria ser lento, uma vez que, ainda segundo ele, "não se pode desenraizar de uma hora para outra um indígena" (O Estado de São Paulo, 2 mai. 1992). Isso equivale a fazer o mesmo que se fazia desde seus primeiros predecessores jesuítas no Brasil, com a diferença apenas localizada no momento em que deve ocorrer esse desenraizamento. Nos primeiros séculos, como já se viu, deveria ocorrer tão logo fosse possível; mais recentemente essa prática se transformou:

Os povos têm direito de voltar às razões de viver de seus avós na convicção de que essas razões vinham e vêm imbuídas da luz do Verbo e da força vital do Espírito. Só a partir disso, se poderá entabular um diálogo com a tradição judaico-cristã e permitir que ela seja assimilada consoante as possibilidades e os limites de cada cultura. (Boff, 1992, p. 68)

O que se deve salientar na postura dessa facção da igreja católica, tomada como a mais progressista, é a preocupação com a própria tradição do grupo que se deseja evangelizar. É necessário que os grupos mantenham sua própria cultura, nem que para isso ela tenha de ser recuperada, e, a partir dela, caminhar para o diálogo judaico-cristão com seus portadores.

Nos itens (ii) e (iii) da definição de Leite et al. (1985). Neles afirmava-se que a educação para os indígenas deveria resgatar a cultura e permitir a incorporação, na escola, de seus conhecimentos científicos. O resgate, pela escola, proposto por essa definição, aparecera referido por Nascimento (1983), como uma forma de 
documentação cultural, pois, a escola deveria "incentivar a salvaguarda da cultura e tradições tribais, pois um homem com tradição tem maiores possibilidades de adaptação a inovações" (p. 157).

Nesse aspecto, a escola era tomada como um veículo capaz de manter valores tradicionais do grupo, que permite a sua atualização nos momentos necessários. Monserrat foi um pouco mais além e tomou a alfabetização por outro ângulo:
A alfabetização pode ser vista como o passo fundamental em direção à auto-realização do ser humano em sua potencialidade máxima atual, ou seja, também como "homo scriba". (1983, p. 117)

A alfabetização tornava-se, pois, um meio para atingir a própria auto-realização, "no máximo" que ela pode, hoje, atingir: a escrita. $\mathrm{O}$ analfabeto, portanto, ainda que a partir de uma sociedade em que a escrita não estivesse presente, mostrava-se definitivamente impossibilitado de atingir sua "auto-realização máxima atual". Novamente, a imperfeição da cultura aparecia como uma característica intrínseca dos grupos indígenas. Desse mesmo ponto de vista, embora sobre outro tema, Lea (1981) questionou-se sobre o fato de que era preciso levar informação do mundo do branco aos índios, mas "como fazer isso sem destruir seus valores e promover deculturação" (p. 65)? A pressuposição da fragilidade cultural desses grupos era sempre a mesma, o que, de certa forma, levava a crer que a escola poderia atuar como uma espécie de anteparo para as relações dos índios com a sociedade nacional.

Nesses últimos anos, entretanto, afirmou-se uma tendência, ainda que demasiado insegura por parte de seus promotores, de deixar os grupos indígenas à mercê de seus próprios interesses. Uma passagem descrita por Oliveira e Diniz pode ilustrar esse aspecto: 


\section{Os Índios e a Alfabetização}

encontramos uma certa resistência do grupo, pois a maioria via na escola, exclusivamente, a função de ensinar a ler, escrever e fazer contas; não se mostravam suficientemente [sic] para os debates, vendo nisso uma perda de tempo. Queriam ansiosamente aprender a linguagem do branco, e havia os que se dedicavam quase que exclusivamente ao estudo. Daí, apesar de continuarmos insistindo nos debates quando surgia uma oportunidade [...], deixamos que eles próprios decidissem sobre a dinâmica do trabalho. (1981, p. 34)

Maria Elisa Ladeira (1981), entretanto, sintetizou melhor essa convergência ao propor o que chamou de "escola semi-analfabeta" - "onde o aprender a ler e a escrever não origina um 'saber maior' nem contribui para o 'desenvolvimento do índio' " (1981, p. 173) —, contrariando a concepção de que os próprios índios não teriam condições de selecionar os elementos da sociedade nacional que lhes poderiam contribuir. Uma observação realizada por Altmann e Zwetsch ilustra bem essa última postura:

a) É grande a insistência dos índios, principalmente jovens, pela instalação de uma escola na aldeia;

b) Dentro das limitações impostas pela dificuldade de comunicação [...], notamos que o modelo de escola que os índios imaginam é aquele que eles vêem nas linhas de colonização do INCRA; as escolas rurais, cuja precariedade é sabidamente conhecida;

c) Será preciso, em decorrência, que os próprios índios percebam que tal escola não lhes interessa, e muito menos responde às suas necessidades decorrentes de contato com a sociedade nacional e, sobretudo, não favorece o desenvolvimento de sua cultura. (1981, p. 46)

A ideia de que os índios não tinham senão uma opaca concepção de suas próprias relações com a sociedade nacional, cujos laços teriam de ser mediados por uma instituição capaz de 
protegê-los do etnocídio a que seriam necessariamente submetidos se os tomassem sob sua própria responsabilidade, transparece lúcida no item "c)" descrito acima. Nesse caso, antes mesmo de a escola mediar-lhes as relações interétnicas, o próprio agente transformador duvidou de sua capacidade para compreender tais relações e, portanto, de descobrir seus anseios mais autênticos. A "escola semi-analfabeta" foi concebida justamente em oposição a essa mentalidade que, variando de intensidade, desconsiderou a capacidade desses índios de compreenderem-se a si mesmos, para, a partir daí, estabelecerem suas relações com a sociedade nacional. O "desenvolvimento da cultura", proposto como uma das consequências mais diretas da escola, foi tomado por Ladeira como um acréscimo indesejável às necessidades indígenas explicitamente formuladas por eles. Esse acréscimo ocorria como prolongamento da educação tornada obrigatória, portanto, necessitando ser controlada a partir de critérios que, ainda, não se coadunavam com os anseios do grupo.

\footnotetext{
Afinal somos sempre nós, brancos, que "sabemos" o quê, como e quando vocês, índios, devem aprender. Continuamos, das maneiras mais diversas e sutis, sendo sempre os dominadores. (M.E.LAdEIRA, 1981, p. 172)
}

Nessa escola, todas as formas de transformação que acompanhavam os processos alfabetizatórios seriam abandonadas, quer fossem em seu benefício quer não. O processo conscientizatório, a que já se referiu anteriormente, que visava a tornar a escola um espaço privilegiado para a discussão das relações que se estabeleciam entre o índio e a sociedade nacional, seria eliminado, tornando-a um espaço exclusivo do ensino formal da escrita e da matemática. Ao se considerar que a exigência indígena sempre fora relativa a essa forma de escola e a esses assuntos especificamente, seu estabelecimento só viria a satisfazer a solicitação do grupo. O conhecimento dos 
grupos indígenas, embora limitado pela sua experiência restrita a uma única forma de escola, dirigia-se para ela a partir de seus próprios interesses.

Como a dar uma forma oficial para o abandono das posturas notadamente paternalistas, ainda que tímido, como se viu, o Documento Final do Encontro Nacional sobre Educação Indígena, realizado em dezembro de 1979, apresentou as seguintes conclusões:

Os participantes desse encontro concordam em que:

1) Deve-se exigir que a voz dos índios seja ouvida e respeitada nas decisões de seu próprio destino.

2) Deve-se lutar pelo reconhecimento da especificidade da educação indígena.

3) Deve-se apoiar toda e qualquer iniciativa organizada pelos povos indígenas para defesa de seus mais legítimos direitos. (M.E. LAdEIRA, 1981, p. 150)

Esse rol de determinações a que se propuseram os participantes do encontro tornou explícito o atrito desconfortável existente na própria instituição que se pretendia instalar nas áreas indígenas. Em ocasião diversa, tal atrito foi tomado sob o outro ponto de vista:

A escola interfere no modo de vida tribal, sem dúvida; por isso mesmo, um projeto educativo não se deve restringir a ela: deve interferir deliberadamente no processo de reordenação sócio-cultural das sociedades indígenas, no qual os agentes educacionais têm um papel de assessoria e orientação. É preciso, porém, distinguir entre dois tipos de interferência: aquela que impõe e manipula e aquela que, dentro de uma pedagogia crítica, respeita os índios como sujeitos de seu destino, ajudando-os na reflexão sobre objetivos e na procura de formas de organização adequadas para alcançá-los. (Relatório Geral apud Emiri; Monserrat, 1989, p. 28, grifo meu) 
Legitimando a ação transformadora da escola pelo respeito ao índio, essa postura presumiu que os agentes culturais estariam capacitados para estabelecer o sentido que tais transformações assumiriam. Em que pesasse o fato de considerar os "índios como sujeitos de seu destino", sobressaía-se a ideia sempre recorrente de que eles precisariam de ajuda e de orientação.

De certa maneira, a educação que sempre se propôs para os índios tem estado, desde os primeiros educadores missionários, até o difuso período do último quartel do século vinte, imersa na imagem do índio ingênuo que se formou desde a chegada dos primeiros portugueses. Assim, cumulativamente, propósitos "salvacionistas" alternaram-se com propósitos "civilizatórios" e "integracionistas", culminando no aparecimento do propósito apenas "orientador", como a indicar que a sociedade nacional atingiu a maturidade suficiente para imaginar o índio fora de sua tutela. Todo o processo educacional voltado para o indígena manteve um vínculo estreito com a atividade especificamente condutora que parece ter dado origem ao termo. 


\section{A educação guarani}

A compreensão da educação para o indígena dificilmente pode prescindir do conhecimento da realidade propriamente indígena para a qual se deseja estabelecer essa escola. Como já se pôde ver, nos projetos educacionais analisados, desconsideraram-se o interesse e a participação do índio nos processos decisórios que se lhe propunham, tomando aquele apenas como recurso para colocá-los no "caminho da salvação", da "civilização" ou da integração na sociedade nacional brasileira. A educação para o indígena, propriamente dita, apesar de solicitada pelo índio, era uma necessidade do próprio educador. Muito embora, várias vezes, tais projetos tivessem caminhado ao encontro dos interesses indígenas, sobretudo no que se refere à alfabetização, o propósito final que orientava a elaboração do corpo das disciplinas que seriam ministradas e das técnicas que seriam utilizadas terminava por conduzir a educação a interesses outros que não eram os que motivaram a presença indígena na escola.

O interesse seguidamente manifesto pelos índios na apreensão de técnicas e instrumentos de origem europeia pode ser tomado como uma tentativa de maior interação com o meio ambiente indígena que se transformava, ameaçando o equilíbrio das relações do grupo, no trato com os demais. Armas, facas, remédios e até o domínio nas relações com a sociedade nacional brasileira, por meio da compreensão da moeda, da escrita, da legislação, etc., eram dados que se poderiam apresentar como recursos, tanto para sua sobrevivência enquanto grupo diferenciado, quanto para o domínio sobre outros. Apesar de "os aspectos adaptativos de um costume ou de uma crença não serem percebidos aparentemente 
pelos membros da sociedade na qual ele se manifesta" (MEGGERS, 1987, p. 222), é preciso compreender como a aquisição de novas técnicas e novos instrumentos poderiam ocorrer para contribuir no restabelecimento desse equilíbrio, cuja perda ameaçaria a própria identidade do grupo.

Em se tratando do caso específico da alfabetização, cumpre conhecer os processos educacionais indígenas e para os indígenas a partir de um e de outro ponto de vista. As formas de transmissão de conhecimento que estão presentes na sociedade em vias de alfabetizar-se pelas técnicas conhecidas da educação ocidental só poderão ser depreendidas mediante o processo de compreensão do seu modo de ser. Apesar das práticas visíveis de ensino que facilmente se podem verificar nessas sociedades, os processos complementares de compreensão da realidade não se dispõem senão pelas vias da interpretação oferecida pelo próprio grupo.

As práticas alfabetizatórias, por sua vez, comumente aplicadas e testadas na sociedade de origem europeia e, via de regra, experimentadas nas sociedades indígenas desde o período colonial, não têm apresentado a eficácia esperada, a não ser individualmente. Os índios alfabetizados não incorporam esse conhecimento ao conjunto de conhecimentos que serão transmitidos a seus descendentes. A alfabetização, pois, mantém-se um fenômeno exclusivamente exógeno, que não pode ser sustentado sem a presença constante do educador estranho ao grupo.

O acesso ao texto escrito, possibilitado pelas práticas alfabetizatórias conhecidas, torna-se um conhecimento individual, que não se permite coletivizar. Mesmo que os agentes envolvidos tenham origem no próprio grupo, as técnicas e os propósitos conhecidos a serem aplicados poderão ser alheios aos interesses e aos meios de transmissão locais. A troca de informações, no convívio diário, pressupõe a história pessoal do falante, cuja fala, apesar de legitimamente identificada pelo grupo, não é igual a nenhuma 
outra porque é exclusiva dele mesmo. Em sua conversão para a escrita há, senão a presença de estranhos capazes de fazê-lo, pelo menos o intermédio da aprendizagem formal da língua, circunscrita à uniformização necessária, tornando-a estática e impessoal, alheia à história pessoal dos falantes.

Para encontrar-se um meio de documentação escrita, bem como de recuperação dos dados que encerra, capaz de adequar esse dinamismo e essa individualidade da fala à rigidez e à impessoalidade da escrita, é necessário fornecer ao grupo não só a chave que codifica e decodifica letras e sons, mas também o conhecimento da própria mecânica do processo alfabetizatório, devidamente adequada à sua própria concepção de mundo. Dessa maneira, seria possível proporcionar ao grupo os meios necessários para a manutenção de sua independência, deixando-lhe a tarefa de estabelecer suas próprias relações entre a fala e a escrita.

A se tomar por base a diversidade de grupos indígenas no Brasil, pode-se prever igual diversidade de conhecimentos e dos meios de transmissão desses conhecimentos. Compreender todos, em suas próprias variações internas, é tarefa para além de um trabalho que vise a encontrar subsídios para a implantação de um processo educacional em um grupo específico. Em que pese a restrição dos resultados obtidos com esse procedimento, a especialização, nesse caso, corre parelha com o propósito de se obter respostas positivas, capazes de estabelecer uma alfabetização permanente e desvinculada da sociedade, da qual o grupo tem necessidade de diferenciar-se.

Conhecer os processos tradicionais indígenas para a transmissão do conhecimento deverá restringir-se, pois, a conhecer os processos do grupo específico em que a alfabetização deverá implantar-se. Nesse caso, as descrições antropológica, linguística e etnográfica podem contribuir de maneira significativa para isso, desde que complementadas pela sua atualização no momento em que se pretende aplicar as técnicas e os instrumentos educacionais desenvolvidos. 
Os grupos guaranis são tratados, inequivocamente, como um só grupo que habita uma extensa região que compreende pelo menos quatro países (Brasil, Paraguai, Bolívia e Argentina) e que se subdivide em vários outros, dificilmente caracterizáveis com o rigor necessário para uma análise etnológica. Basicamente, os autores são unânimes em considerar, dentro do território brasileiro, os subgrupos Kaiwá e Mbyá. Um terceiro grupo, entretanto, que Schaden (1974a, p. 2) denominou Nandéva, dificilmente poderá ser tomado com a mesma certeza. Reporta-se esse autor a uma reunião de vários grupos, não identificáveis rigorosamente: Apapokúva, Tañyguá e Xiripá. Os trabalhos de Curt U. Nimuendaju entre os Apapokúva, de León Cadogan entre os Avá-Guaraní e os Jeguakáva-Tenondé, do General Samaniego entre os Mbyá, de Egon Schaden entre diversos subgrupos Guaraní, de Bartomeu Meliá, também entre diversos subgrupos, e os de Maria Inês Ladeira entre os Mbyá do Litoral de São Paulo, podem oferecer um vasto material para seu estudo, coletado nas próprias aldeias.

A extensão territorial e a ausência de unidade política entre eles, genericamente considerados, não impedem que, em cada aldeia que formam, seja possível encontrar, num espaço limitado, uma hierarquia política e uma unidade cultural entre todos, perfeitamente auto-identificados com os demais, de outras aldeias. Sua população pode oscilar em algumas dezenas rapidamente, pelo nomadismo comum de cada indivíduo, sem perder sua própria identificação. Cada aldeia pode ser tomada como um ponto de referência guarani em todo o vasto território do grupo.

O estabelecimento de áreas indígenas oficiais sobre o território nacional brasileiro parece apenas determinar o local para onde devem dirigir-se. Em pouco tempo, todos percorrem todas as áreas formando novas famílias ou reencontrando as antigas, permanecendo em cada aldeia por um período que pode variar de alguns dias a vários anos. Por qualquer razão inesperada, advinda 
de sonhos, rivalidades pessoais ou até de mercado de trabalho, desfecham-se as mudanças, das quais participam indivíduos isoladamente ou em família, deixando para trás o que não se julgar conveniente carregar, ainda que fossem alguns dos filhos, pais, marido ou esposa. $\mathrm{Na}$ aldeia, todos os que ficam têm o seu lugar próprio, seu direito à chefia, sua roça, sua família e tudo o mais que souberem ser. Para isso, basta tomar decisões que interfiram na vida de todos, cultivar o terreno que estiver disponível e casar-se; restará apenas que os demais acatem as decisões, que a plantação cresça e que alguém queira casar-se. Nesses pequenos espaços disponíveis, sobre os quais se erguem as chamadas aldeias, que eles chamam ñane rekoa ('nosso lugar de estar como somos'), sob o rigor aparente de Conselhos bem estabelecidos, "Caciques", "Vice-Caciques", "Representantes", "Presidentes", "Secretários", prevalece o prestígio pessoal construído por suas próprias realizações.

Tendo-se em vista o desenvolvimento de práticas alfabetizatórias no grupo Guarani da A.I. Guarani do Ribeirão Silveira, cumpre tentar compreender a visão que os Guarani têm de si mesmos e de suas formas de transmissão do conhecimento, além da maneira pela qual interpretam a escrita, a leitura e os seus processos de aprendizagem.

Para os Guarani, "escrever” diz-se "ñambopará", ou "nós escrevemos". O termo é composto do pessoal "ña-" (variante nasal de " $\mathrm{ja}-$ "), que indica primeira pessoa do plural inclusiva e ativa, do causativo "mbo-", e de "pará", que indica algo como "o desenho que se faz nos trançados artesanais de palha”. A expressão, em seu conjunto, reporta-se ao ato de executar um desenho continuado, mas não reto, próprio da escrita. "Ler", por sua vez, pode dizer-se “jaexakuaá”, composto de “ja-”, “exa-”, que significa "ver”, e "kuaá-", que significa "saber", "sabermos ver"; mas também pode-se dizer "jaroayvu”, que se decompõe em "ja-", "ro-", comitativo que indica "fazer", e "ayvu”, que se pode traduzir por "falar". Entretanto, 
o comitativo "ro-" pressupõe que a ação esteja sendo realizada em conjunto com o sujeito e por causa dele; por exemplo, "aronha kavaju" significa "fiz o cavalo correr, montado nele" (Dooley, 1990, p. 129), diferentemente de "amonha kavaju”, que significa "fiz o cavalo correr, assustando-o". Se o primeiro termo indica simplesmente "saber ver", o segundo, "fazer falar, por falarmos", tem implicações etnolinguísticas que merecem ser abordadas detidamente.

A priori, a tradução de "ayvu" por "falar" não pressupõe que haja qualquer correspondência unívoca entre esses termos. Nimuendaju afirma que “ 'ayvu' significa no dialeto Apapocúva [...] língua, e em Guarani antigo 'ruído’” (1987, p. 29). Cadogan o traduz por "hablar; lenguaje" (1992b, p. 35). Schaden é categórico ao afirmar que "ayvu significa mais propriamente linguagem" (1974a, p. 112). Dooley o averba como "idioma" e, ainda, como "qualquer unidade de fala: discurso, frase, palavra, etc." (1990, p. 39). Muito embora todos estejam concordes com essa tradução, também estão, pelo menos os três primeiros, com a ideia de que o termo "ayvu" reporta-se a mais do que simplesmente "fala".

Nimuendaju afirma que os Apapocúva chamam alma de "ayvucué, interpretando a forma como:

ang - alma (Guarani antigo) que muda foneticamente em ây no Apapocúva; vu surgir; cué - pretérito. Portanto: alma surgida (do corpo). (1987, p. 29)

Embora a interpretação do termo proposto por Nimuendaju possa estar sujeita a revisões, a noção de desagregamento presente em -cué evidencia que o ayvu, nesse caso, está sendo tomado fora do corpo, para além da enunciação. Compare-se com as expressões "uru ro'okue", que se pode traduzir como "carne de galinha", ou, mais propriamente, "carne que já não está mais na galinha"; ou "xe ra'yxykué, que se pode traduzir como "minha antiga mulher", 
ou, mais propriamente, "a mãe dos meus filhos que não está mais comigo", isto é, "que, apesar disso, continua a ser a mãe dos meus filhos", semelhantemente à carne da galinha que continua a ser de galinha. Dessa maneira, depreende-se que o ayvu seria a alma dentro do corpo vivo.

Cadogan reporta-se à expressão "ayvu rapyta" dizendo "(literalmente: origen del lenguaje humano), significa segun los dirigentes mbyá, lo que llamaríamos origen o germen de la porción divina del alma" (1992b, p. 302). Para rapyta, ele averba "origen; base; fundamento; extremidad en que comienza la cosa" (1992a, p. 43), portanto, "fundamento da fala", ou, como ele mesmo reproduz, "germen de la porción divina del alma". "Ayvu" está novamente tomado por alma, segundo se pode depreender em "porción divina del alma”. À semelhança do que se viu na explicação de Nimuendaju, para Cadogan, se "ayvu rapyta" é a origem da alma, "ayvu" seria a alma. Literalmente é o que ele afirma:

[...] las voces ayvu, ñe'ey y 'e traducen los dobles conceptos de:

1) Lenguaje humano, origen de la porción divina del alma humana.

2) Palabra, porción divina del alma.

3) Decir: el princípio vital; el alma, el decir (Verbo). (CADOGAN, 1992a, p. 303)

Schaden, por sua vez, recupera esses sentidos:

O ayvu — ou: os ayvu, conforme o caso - é de origem divina, isto é, participa da natureza dos espíritos sobrenaturais. É responsável pelos desejos, sentimentos e manifestações mais nobres do indivíduo. A função primordial, básica, da alma é a de conferir ao homem o dom da linguagem. (1974a, p. 112) 
Assim, para ele, o ayvu é a alma que confere a língua ao homem, além de ser responsável pelos "sentimentos e manifestações mais nobres”. Meliá considera-o pelo mesmo aspecto:

Duas, três e até mais almas estariam presentes e atuando no guarani. Mas de todas elas a "sublime" e o núcleo inicial da pessoa é a "palavra", ayvu ou ñee e, como tal, porção divina por participação; palavra; [...] é boa e indestrutível. (1989, p. 310)

Dessa maneira, a expressão jaroayvu, que se permite traduzir simplesmente por "lermos", pode ser interpretada pelo viés da religiosidade, como a efusão, pelo leitor, do ayvu contido no papel. Nesse caso, para que se compreenda essa relação entre o que já se definiu como palavra-alma, com a escrita e, portanto, com a ação alfabetizatória, é necessário compreender o próprio ayvu e as relações que se estabelecem entre ele, o indivíduo e a comunidade.

Schaden afirma:

\footnotetext{
Para a compreensão da mentalidade educacional do guarani

[...] cumpre saber qual o conceito da pessoa humana inerente a cultura. Este baseia-se, em parte, na teoria da alma ou das almas de que o indivíduo é portador. (1974b, p. 11)
}

Segundo diversos autores (NimuendaJu, 1987, p. 29-34; Cadogan, 1992a e b, p. 302-307; Schaden, 1974a, p. 111-115; Melí́, 1989, p. 310-311; Bartolomé, 1977, p. 73-76; Ladeira, 1992, p. 117-118), os Guarani contam com mais de uma alma para sua existência. Uma delas, o ayvu, ou ñe'e, ou ainda outro nome que tenha, é necessariamente boa, enquanto que uma outra, pelo menos uma - axygua, anguery, $\tilde{a}-$, pode causar algum transtorno ao indivíduo. Aquela, de origem imediatamente divina, recolhida e reconhecida pelo pajé, reporta-se, como já se viu, ao que se considera "manifestações mais nobres". Esta, de origem 
imediatamente terrena, animal, reporta-se aos instintos mais violentos e indomados.

Nessa metafísica das almas guaranis, o ayvu aparece como a porção do indivíduo que o capacita não só à fala e ao convívio social, mas também ao próprio domínio de suas emoções e de seus instintos. Cadogan afirma, nesse sentido, que "desde edad temprana se le inculca al joven Mbyá la necessidad de dominar a 'mbochy', comenzandose a impartírsele estas enseñanzas después de la ceremonia de darle nombre" (1992a, p. 71). Nessa cerimônia, que Nimuendaju chamou ñeengarai, ocorre justamente o "batismo". Nimuendaju descreveu-o.

[...] vão-se chegando todas as mulheres e moças para participar; sentam-se em linha, ao longo da parede, com o rosto voltado para o leste, enquanto os homens se mantêm distantes. E assim prossegue o canto, horas a fio. Entretanto o pajé vai recebendo, vez por outra, forças mágicas sobrenaturais das potências a que dirige o seu canto, que transmite à criança. Parece que eles concebem estas forças de modo bastante substantivo, alguma coisa como um tecido, apenas invisível aos mortais. O pajé como que apanha no ar com as mãos esta matéria, por cima de sua cabeça, enrola-a e então a desdobra sobre a criança. Ele também transmite sua própria força mágica à criança: seja tirando-a como se desveste uma camisa, suspendendo-a pelas costas, seja tirando-a do seu peito, com um movimento circular da mão sobre ele e estendendo-a então cuidadosamente sobre a criança. (1987, p. 30)

Nesse caso, a alma é tratada como algo a ser colocado no indivíduo. Vem acompanhada do que o autor chamou "força mágica", que se transfere do pajé para o indivíduo. Cadogan descreve o ritual: 


\section{Os Índios e a Alfabetização}

[...] poniéndose en comunicación con los dioses, averigua la procedencia de la palabra-alma que se ha encarnado en el niño. Enciende la pipa, sopla echando humo sobre la coronilla del niño y comunica a la madre el patronímico sagrado que le corresponde. (1992a, p. 73)

Apesar de partir do princípio de que a alma, por si mesma, encarnou-se no indivíduo, Cadogan acrescenta que o pajé sopra a fumaça do cachimbo sobre a cabeça do batizando. Meliá faz, rapidamente, uma descrição semelhante:

O mitã renói $a$, o que chama ou dá nome à criança, se prepara para receber a revelação. Acende o cachimbo, lança baforadas de fumaça sobre o cucuruto da criança e finalmente comunica à mãe o nome averiguado. (1989, p. 312)

A respeito da capacidade controladora do $a y v u$, que se superpõe à porção animal representada pelo acyigua de Nimuendaju, ou pelo mbo axy de Cadogan, ou mesmo pelo ã de diversos autores, ainda que notada diferentemente como "acanhamento, desconfiança, persistência e apatia” (KRUG, 1924, p. 337; LACERDA, 1954, p. 243 , Cherobin, 1986, p. 134), é interessante cotejar com o que propõe Geertz a propósito da natureza humana:

Não dirigido por padrões culturais - sistemas organizados de símbolos significantes - o comportamento do homem seria virtualmente ingovernável, um simples caos de atos sem sentido e de explosões emocionais e sua experiência não teria praticamente qualquer forma. A cultura, a totalidade acumulada de tais padrões, não é apenas um ornamento da existência humana, mas uma condição essencial para ela - a principal base de sua especificidade. (1989, p. 58)

A concepção guarani de ayvu, atuando sobre uma, ou mais de uma, alma incontrolada, vem bem ao encontro dessa 
proposição de Geertz. A um só tempo, essa metafísica explica e organiza o comportamento do indivíduo. Muito embora não se possa encontrar um conjunto formal que descreva as relações que se estabelecem entre as almas, ou entre elas e o indivíduo, ou entre elas e o grupo, é possível verificar-se que a conduta guarani é predominantemente marcada por esses princípios. Cada um tem a consciência de que tais relações existem e que podem atuar sobre elas. Entretanto, Meliá chamou a atenção para o seguinte:

\begin{abstract}
A experiência religiosa guarani leva a um paradoxo como o seguinte: as ideias sobre o mundo sobrenatural, sejam de caráter psicológico ou mitológico, nos são traduzidas e comunicadas por indivíduos concretos que se consideram inspirados, e o próprio desses indivíduos é que se sentem, cada um deles, criadores de suas próprias mitologias. Se eles explicam algo, não explicam um texto normativo anterior a eles mesmos, mas o que acabam de escutar e cantar como palavra inspirada. (1989, p. 332)
\end{abstract}

A explicação, nesse caso, parece individualizar-se entre os Guarani, o que poderia levar a uma multiplicidade de "sistemas organizados de símbolos significantes" e atingir o "caos de atos sem sentido e de explosões emocionais" de Geertz. Isto é, a multiplicidade comprometeria o próprio ayvu, como princípio controlador das porções do indivíduo, tornando-o impossibilitado para o próprio convívio social. Coletivamente, isso seria o fim do grupo.

Entretanto, apesar de as práticas da tradição oral não estarem sujeitas às normas cristalizadas da transmissão de conhecimento pela escrita, é possível encontrar nelas alguns princípios que regem a realização.

Ao classificar as "formas fundamentais da tradição oral", Vansina (1982, p. 160) estabelece quatro categorias - poema, fórmula, epopeia e narrativa - , distribuídas da seguinte maneira: 


\begin{tabular}{|c|c|c|}
\hline CONTEÚDO & fixo & $\begin{array}{c}\text { livre escolha } \\
\text { de palavras }\end{array}$ \\
\hline estabelecida & poema & epopeia \\
\hline livre & fórmula & narrativa \\
\hline
\end{tabular}

A narrativa, cuja forma e conteúdo são de livre escolha do indivíduo, parece ser aquela que melhor se conformaria com a tradição guarani. Ele descreve a narrativa:

A última categoria é a das "narrativas", que compreendem a maioria das mensagens históricas conscientes. Nesse caso, a liberdade deixada ao artista permite numerosas combinações, desenvolvimentos, etc. Torna-se, então, difícil reconstruir um arquétipo. $\mathrm{O}$ artista é completamente livre, mas somente do ponto de vista literário: o seu meio social pode, às vezes, impor-lhe uma fidelidade rígida às fontes. (VAnsina, 1982, p. 161)

Apesar da liberdade deixada ao narrador, segundo Vansina, salvaguarda-se a tradição das modificações virtuais decorrentes dessa liberdade pela possibilidade de um controle social das fontes. Por outro ponto de vista, mas com resultados semelhantes, Bakhtin considera que "qualquer enunciação, por mais significativa e completa que seja, constitui apenas uma fração de uma corrente de comunicação verbal ininterrupta (concernente à vida cotidiana, à literatura, ao conhecimento, à política, etc.)" (1981, p. 123). Ou seja, mesmo as narrativas guaranis fazem parte dessa "corrente de comunicação verbal", da qual recuperam a maior parte dos dados de que dispõem e para a qual contribuem de maneira bastante comedida. Pode-se esperar das narrativas individualizadas guaranis a predominância da forma e do conteúdo das narrativas anteriormente já realizadas. A originalidade de cada uma estará sujeita à história pessoal do narrador que, dessa forma, expõe e distribui suas experiências anteriores, por meio dos detalhes específicos que a compõem. 
A manutenção dessa unidade, isto é, o controle social das fontes e a corrente de comunicação verbal, realiza-se, entre os Guarani, exatamente pela expressão coletiva das diversas narrativas individuais. A esse respeito, Schaden explica que o porahê $i$, realizado com frequência nas aldeias, "é a um tempo expressão de individualismo e coletivismo":

De um lado faz parte de todas as cerimônias coletivas, das quais é inseparável, e de outro cada indivíduo em particular tem ou pode ter os seus porahêi próprios e inalienáveis, recebidos pessoalmente, em sonho de algum espírito protetor. (1974a, p. 118-119)

A criação individual de "sistemas organizados de símbolos significantes" que orientam e explicam a conduta guarani termina por imergir numa criação coletiva que assegura a coesão cultural do grupo. Com isso, a unidade étnica se produz em torno da expressão conjunta desses purahêi, que, além de muitas outras funções, atua no sentido de instaurar as bases sobre as quais as futuras narrativas serão realizadas.

A relação que as almas mantêm entre si, com o indivíduo e com o grupo, pode-se explicar diferentemente a se tomar por base uma narrativa específica, ou várias delas. Entretanto, considerando-se o caráter coletivo de sua manifestação, será possível compreender, desse ponto de vista, as formas de controle e de explicação da conduta guarani.

A se tomar ayvu a um só tempo "alma" e "fala", a ilação de serem as narrativas uma forma de seu extravasamento parece convergir para a ideia de que o ayvu é o "princípio regulador" do comportamento humano. Disso, pode-se deduzir, também, que o conhecimento de um grande número de narrativas indica a presença de um ayvu forte e capaz de manifestar-se continuadamente. Se, no caso guarani, as narrativas realizam-se por meio dos purahêi, 
serão eles um dos meios pelos quais se poderá controlar e obter controle sobre a própria conduta.

A participação nessas manifestações coletivas será, pois, fundamental para o desenvolvimento do indivíduo e do grupo. Estar ausente dessas ocasiões poderá acarretar a perda do autocontrole e, portanto, o "caos de atos sem sentido e de explosões emocionais". Na conduta diária, tomado como consequência direta da participação nessas ocasiões, o ayvu se manifesta, sobretudo, pelo controle das emoções individuais e pelo aprendizado da fala e de outras atividades.

$\mathrm{Na}$ A.I. Guarani do Ribeirão Silveira, pouco se pode verificar que desautorize essas considerações. O primeiro contato que fiz com essa área foi em março de 1991. Lá, estão localizadas duas aldeias - Silveira e Boraceia —, em que vivem, aproximadamente, uma centena de pessoas, das quais mais da metade deve ter menos de doze anos. A aldeia da Boraceia fica logo na entrada da área e nela localizam-se o posto da Funai e a enfermaria. A aldeia de Silveira está no interior da Serra do Mar, a uma hora de caminhada a partir da Boraceia, ou a duas horas a partir da Barra do Una. Pelos dois caminhos, a aldeia de Silveira isola-se da população regional por uma larga faixa de mata atlântica, que só se permite cruzar a pé.

A primeira visita que realizei a essa área deixou-me impressões mal compreendidas que, apenas aos poucos consegui relacionar à maneira de ser do grupo. De modo geral, o laconismo de todos sobressaía-se e não me permitia conduzir as conversas para qualquer tema que eu desejasse, como a demonstrar uma certa antipatia pelo interesse que eu tentava demonstrar. Apenas quando falamos da escola, a conversa pareceu ter um outro sentido. A descrição do primeiro encontro que tive com eles é a maneira que melhor permite traduzir essas impressões.

Participamos dessa viagem Sérgio Damy² e eu. Saímos pela manhã, de São Paulo, em direção ao litoral norte do estado.

2 Antropólogo, da antiga área de Etnologia do Museu Paulista-USP, atualmente incorporada ao Museu de Arqueologia e Etnologia-USP. 
Na Barra do Una, município de São Sebastião, deixamos o carro e caminhamos em direção à Serra do Mar. Logo nos primeiros metros de estrada de chão batido, cruzamos com alguns índios que iam vender palmito na estrada. Sérgio perguntou se Samuel, cacique da aldeia, estava por lá, ao que recebeu uma resposta afirmativa, extremamente breve.

Continuando pelo caminho, cruzamos com mais duas índias e umas seis ou sete crianças, que também carregavam palmitos. Uma delas levava um carrinho de mão com muitos palmitos dentro. Ao nos cruzarmos, cumprimentamo-nos com um rápido "Bom dia", de longe, e um quase imperceptível meneio de cabeças. Fomos correspondidos da mesma maneira, apenas pelas índias. Ao ficarem para trás, ouvimos risadas e, entre uma e outra palavra em guarani, era possível reconhecer o termo jurua, que eles usam quando se referem a nós em oposição a eles.

Já no mato, chegamos às margens de um rio, ou ribeirão, provavelmente o Silveira, onde havia uma placa da Funai, estabelecendo esse limite da área. Seguimos pela trilha em direção à aldeia. Aos poucos, alguns sinais indicavam sua proximidade. $\mathrm{O}$ caminho estava mais limpo, com mato, ainda verde, já derrubado, palha de milho pelas margens da trilha e alguns troncos deslocados. Logo à nossa direita, avistamos uma primeira casa, construída de troncos de madeira, colocados em pé, um ao lado do outro, e coberta de sapé. A casa era quadrangular, como todas. Ficava em terreno limpo, plano e de terra bem batida.

Seguimos em frente, pois não havia ninguém nessa primeira casa, chegando a outra em que havia um casal de velhos. Alguns cães, assim que nos notaram, aproximaram-se rosnando e latindo, mas, sob os gritos incompreensíveis da senhora, fugiram amedrontados. O senhor, que estava deitado na rede, levantou-se e veio ao nosso encontro. Descalço, vestia uma calça e uma camisa. Cumprimentaram-nos em português, ele e a senhora. Indagado 
sobre a localização da casa do Samuel, indicou-nos o caminho e nos levou até lá.

Foi um breve percurso, no meio de um capim alto, como a denunciar que a terra já fora cultivada e agora estava disponível. $\mathrm{Na}$ aldeia guarani, as casas estão próximas umas das outras, mas isoladas. De algumas delas é possível avistar outra, mas, em nenhum local, elas formam um centro com aparência de vila ou de aldeia. Parecem-se mais com pequenos sítios localizados próximos uns dos outros.

Ao chegarmos à casa de Samuel, fomos recebidos pelo sorriso de sua mulher, Doralice, que de longe nos avistara. Samuel, de costas, encostado na parede de sua casa, virou-se para nós e nos cumprimentou. Fazia já algum tempo que o Sérgio não ia à aldeia e, pela frieza com que foi cumprimentado, pensou não ter sido reconhecido. De pronto, reapresentou-se a Samuel, que manteve a mesma aparência, bem oposta aos abraços efusivos de grandes amigos, e comentou algo como "até que enfim você veio".

Após essa recepção, sentamo-nos em círculo para alguma prosa. A mulher de Samuel serviu-lhe um prato (que parecia ser de alumínio) de arroz e feijão, que, após oferecer-nos, comeu com algum prazer. Ele estava sentado numa cadeira, comendo sobre uma carteira de colégio, de fórmica verde. Aliás, entre a casa do senhor que nos acompanhou e a casa do Samuel, passamos por uma construção semelhante à das casas, em que havia algumas carteiras e um quadro negro: provavelmente, uma escola. Imaginei que Samuel houvesse apanhado a carteira de lá. Foi surpresa para mim, pois era conhecido que ele sempre se mostrara contrário ao estabelecimento de escola por ali.

Samuel Didiocó é o líder político e espiritual do grupo que se espalha em uma longa área, da Barra do Una até a Boraceia, demarcada e garantida após intensa disputa com empresário do grupo Peralta de supermercados, que se dizia dono de tudo aquilo. 
Estivemos ali sentados, conversando por algum tempo. Tentei arriscar umas e outras palavras em guarani, nem sempre bem-sucedido, mas sempre com sucesso para o humor da conversa. Eles pareciam achar muita graça nessas tentativas. O senhor que nos acompanhou perguntou-me o nome - mbaéixa ne réra? ao que respondi-lhe e perguntei-lhe o dele - 'ha ne?' -, ao que disse "Chico", com pronúncia africada. Em ambas as pernas, na altura da canela, ele tinha muitas feridas, cujo nome guarani ele disse karãi. Pareciam sequelas de picadas de mosquito, já escarificadas de tanto coçar. Depois, eles próprios chamaram-me a atenção que poderia ser impetigo, em consequência, talvez, dessa escarificação. Ele havia passado alguma medicação, pois sua perna estava toda colorida de vermelho.

Após essa conversa entre os quatro interlocutores e a mulher, Doralice, que, mais afastada, em pé, ouvia tudo atentamente, participando algumas vezes, pedimos autorização ao Samuel para erguermos uma barraca ali, mais à frente, próxima de sua casa; coisa que nos foi consentida rapidamente e sem vacilos.

Seguindo o manual, esticamos daqui, puxamos dali, quando, com os olhos fixos e assustados, Sérgio apontou para algo que estaria ao meu lado. Assustei-me também, saltei para o lado e logo vi o brilho vermelho de uma cobra coral enrolada em si mesma. Os índios, ali distantes, notaram que algo estava acontecendo. Eu disse "mbói". Sorrindo com o pulo e com o susto dos dois, as crianças correram na direção da cobra, cuja cabeça já havia sido arrancada antes de nós a virmos, pegaram-na e voltaram sorridentes para casa.

Refeitos do susto, continuamos a montar a barraca, trocamo-nos e fomos para o ribeirão tomar banho. Havia dois caminhos, um certo e um errado. Escolhemos o errado. Voltamos, com todos já, de novo sorridentes, à nossa espera, e com as crianças a nos apontar o caminho certo. Subimos o ribeirão até uma piscina que 
se formava um pouco antes da cachoeira. Na volta, cruzamos com um índio jovem, cujo nome é Zé Duda, que nos cumprimentou com um largo sorriso, dizendo que depois nos visitaria. Continuamos até chegar ao caminho que nos levaria de volta. Antes, porém, resolvemos visitar seu avô, o velho Gumercindo, que, já cego, havia sido cacique da Barragem e agora estava pelo Silveira com sua mulher.

Na casa de seu Gumercindo, ficamos numa conversa cujo ritmo pouco diferia da conversa anterior com Chico e Samuel. Estávamos Sérgio, seu Gumercindo, eu e Armindo, outro morador que, com sua família, cuidava de mais três crianças que estavam por ali, sem os pais. Depois de alguma pouca conversa, seguimos o caminho de casa.

De volta, ficamos ali, sentados, conversando um pouco, no mesmo ritmo das demais conversas. Próximos de nós, ao lado da casa, as crianças brincavam com bolinhas de gude. Mostravam ter grande habilidade, acertando uma bolinha na outra a uma distância de muitos metros. De onde eu estava, podia ouvir sua conversa. Falavam quase que todo o tempo em guarani, com uma pronúncia bem pouco articulada e bastante entrecortada: "eju”, "eru xévy"... Alguma coisa falavam em português, como "corrida", "puta merda", ou a contagem de pontos. Levantei-me para ouvi-los, fingindo observá-los de longe, mas logo ficaram quietos. Samuel levantou-se também e pusemo-nos a conversar por ali. Perguntei-lhe sobre o uso das línguas guarani e português na aldeia, sobre a escola; mas ele não quis falar sobre isso.

Contou a história de um índio, mestiço, que fora morar lá com eles. Um dia, ao embriagar-se, esse índio tentou matá-lo e a um amigo, não índio, que também morava lá; foi expulso. Tomado pelo tema da bebida, contou que havia imposto uma lei, na qualidade de chefe, proibindo todo tipo de bebida na área. Contou um e outro caso de índios que se embriagaram e acabaram tomando atitudes contrárias à vida da aldeia, chegando, algumas vezes, a atuarem como testemunhas de invasores de terras. 
Pouco antes dessa conversa, havia, no fogo, diretamente sobre a brasa, alguns peixes pequenos, "piky". Foram pescados pelo próprio Samuel, com anzol. Comi dois deles. Tinham carne macia, mas era difícil comê-los, uma vez que não foram limpos quando estavam crus. Tínhamos de limpá-los quentes, com as mãos. As crianças comiam-nos inteiros.

Em pé, assistindo ao jogo das crianças, continuamos nossa conversa. Sérgio queria saber de algo a respeito de plantas curativas. Entretanto, as respostas eram curtas e pouco explicativas. Falou-nos apenas das possibilidades curativas da folha de mandioca e da folha de batata, esta para dor de dente. Falou, também, que há dois tipos de doenças: doenças de branco e doenças de índio. "Doença de branco cura com remédio de branco, doença de índio, com remédio de índio". Contou-nos, ainda, que, havia pouco tempo, ele mesmo andara doente e se curou. "Doença de índio?", quis saber o Sérgio. "Não, doença de branco", ele falou, "problemas de fígado, parece, que resolvi no posto da Funai, na Boraceia".

Segundo conta o próprio Samuel, a aldeia se dividiu em duas, não por motivos de briga, como eu já ouvira dizer, mas por questões estratégicas de tomada de posse da área indígena demarcada para eles. Ainda, segundo ele, na parte do ribeirão Silveira, moram em torno de cem índios Ñandéva, ou um pouco menos, e, na área da Boraceia, pouco mais de cem. Lá fica, também, uma enfermeira sobre a qual ele não soube precisar se morava no posto, na vila ou na aldeia.

Como já escurecia, procurei trocar algumas ideias a propósito de astronomia. Falei-lhe em "jasy tata" e perguntei-lhe se havia nomes para elas: disse-me que não e logo desviou a conversa para outro assunto. Falamos de caça. Perguntei-lhe se ainda havia ou não por lá e se ainda caçavam. Suas respostas eram sempre negativas e pessimistas: não havia mais caça porque já fora toda espantada, não têm mais espingarda por isso não podem caçar 
o que resta. De pronto, o Sérgio perguntou das armadilhas monde - e o assunto foi outra vez desviado. Começou a falar dos cachorros, que eram bons na caça aos tatus. Nem era preciso treiná-los, bastando uma simpatia realizada na hora certa, que eles aprendiam. Sérgio quis saber de mais detalhes dessa simpatia e, outra vez, o assunto foi desviado.

Anoiteceu rapidamente e esfriou na mesma velocidade. Como tínhamos as roupas molhadas, fomos todos nos sentar dentro da casa, em volta do fogo. A casa era repartida em três aposentos: um quarto grande no fundo, onde pareciam dormir os meninos menores e os maiores, bem como uma menina, chamada Lúcia, com uns dezesseis anos. Daquele quarto, à noite, enquanto conversávamos, podia-se ouvir um rádio ligado que tocava lambadas, cuja letra em português todos sabiam de cor, cantando em coro com o rádio. Vez ou outra, saía um dos meninos correndo pela porta, e outro logo atrás. Não consegui descobrir de qual jogo se tratava.

Adiante desse quarto, havia outro, um pouco menor, no qual havia uma criança pequena, dormindo. Mais adiante, ainda, havia outro aposento, de três paredes, onde estávamos.

Doralice é a segunda mulher do Samuel. Ela é a mãe de Lúcia, que, por sua vez, é mãe do menino pequeno que dormia no quarto. Calculei quase dois anos para ele. Caminhava sozinho mas com dificuldade; tinha as pernas bem arqueadas e, frequentemente, eu o via sozinho, caminhando pelas redondezas da casa, atirando milho às galinhas, correndo atrás dos gatos ou surrando os cachorros. Uma das cadelas parira recentemente e tinha crias ainda pequenas. Sempre que uma delas se desgarrava das demais, ele corria para colocá-la junto das outras. Durante o jogo com bolinha de gude, corria atrás das bolinhas e as apanhava estragando as jogadas. Em nenhum momento foi censurado ou sequer persuadido para não fazê-lo. 
Havia dois meninos de aproximadamente 10 anos, um dos quais fora apanhado para criar, por Doralice, uma vez que seus pais haviam morrido. E havia também um jovem, um pouco mais velho do que aqueles, talvez com uns quatorze anos, ou pouco mais, filho de Doralice, que não me dirigiu a palavra, sequer o olhar, nenhuma única vez.

Já havia anoitecido, quando Lúcia descascou algumas bananas verdes e as fritou numa panela que pôs ao fogo. Os cães se aproximaram. Ela disse: "sai, Tigre", ao que seu filho, já acordado, correu para espancar o cachorro no meio da noite. Depois, sozinho, ele voltou. Enquanto fritavam as bananas, pus-me a praticar o guarani, perguntando à moça se ela ia fazer bananas fritas. Não me lembrava muito bem como se dizia "fritas" em guarani, mas, para o deleite geral, arrisquei assim mesmo: "rejapo pakova korõrõ?" ("rejapo" significa 'você faz', "pakova", 'banana', e "korõrõ", eu pensava que fosse "frita".) Doralice olhou-me rindo e Lúcia olhou para ela e repetiu em tom de troça: "pakova korõrõ". Não olhou para mim, só para Doralice. Percebi que havia errado alguma coisa. Com certeza o tal do "korõrô". Perguntei a Lúcia como falava "fritas" e ela, sem tirar os olhos da panela, disse "xyryry", com voz bem baixa, então olhou para a mãe que repetiu, alto, forte e sorridente, "pakova xyryry". Segundo ela, "korõrõ" é algo como "rosnar" (o cachorro). Passado esse incidente, Samuel dispôs-se a contar como foi sua disputa com o grupo Peralta, na posse da terra.

Durante sua narrativa, ele disse que nasceu no Silveira, foi para Peruíbe e depois voltou. Aproveitei a ocasião para perguntar se ele havia viajado. Ele disse que não, que sempre vivera por ali desde muito tempo. Seu batismo, segundo ele, fora feito ainda nos tempos de Anchieta, quando então eles eram chamados de Tupinambá. Após um pouco mais dessa conversa, sonolentos, comemos mais uma rodada de bananas fritas e fomos dormir.

$\mathrm{Na}$ barraca, ouvimos barulhos de passos e cochichos. Apagamos a luz da lanterna e vimos as sombras dos meninos 
engatinhados procurando assustar-nos. Sem pensar que já haviam sido descobertos, puseram-se a imitar barulho de onça e correram de volta para casa.

Quando o dia clareou, levantamos. Eram quase seis horas. Todos na casa já haviam levantado. Tomamos nosso café por ali mesmo. Em seguida, fui para junto do fogo, dentro da casa, onde Doralice cozinhava alguma coisa. Ficamos numa conversa lenta, que, aos poucos, procurei dirigir para sua história de vida. Soube, então, que nascera no Paraná, foi para Barragem e, depois, para o Silveira.

Samuel veio do quarto já vestido de calças e camiseta. Perguntei-lhe se ia trabalhar. Disse que não, porque era domingo. Doralice serviu-nos um café muito fraco e muito doce, e Lúcia, que recém chegara junto do fogo, já colocou mais bananas verdes para fritar. Quando ficaram prontas, eu as comi, como todos. Depois disso, perguntei ao Samuel o que seria o esqueleto de construção que havia ao lado de sua casa. Respondeu que seria uma outra casa, uma casa nova, porque a atual já está com mais de vinte anos e não servia mais. Fiquei surpreso com a ideia de uma casa de troncos e cobertura de sapé durar vinte anos, mas ele procurou completar meus pensamentos afirmando que o segredo é a lua em que se colhe a madeira e o sapé. Na lua certa, é possível que ela dure mais do que trinta anos. Sérgio tentou descobrir um pouco mais de informação sobre isso e a conversa foi desviada: ofereceu-nos palmito.

A princípio aceitei sua oferta, acreditando tratar-se de um presente. Mas não era, era venda, como depois eu descobri. Desavisadamente, aceitei duas dúzias. Como pesavam muito, Samuel fez com que o menino descascasse todos, até aliviar o peso. Descoberta a confusão que fiz, acabei ficando com meia dúzia e Sérgio com outra meia dúzia. Com o propósito de ir buscar o dinheiro na barraca, trouxe-lhes também minha caixa de primeiros socorros, com remédios para febre, queimadura e machucados. Nada disso me desobrigou do pagamento. Levamos os palmitos para a barraca e, quando voltamos, Zé Duda estava lá. 
A conversa iniciou como todas as demais: em ritmo lento, cada qual falando a seu próprio respeito. Mas logo descobrimos que Zé Duda era monitor da escola e que havia passado pela escola do SIL no Rio das Cobras, no Paraná. Desse momento em diante, a conversa fluiu mais facilmente. Inteirei-me da inexistência, ainda, de qualquer cartilha ou livro de leitura Nandéva e dispus-me a elaborar uma em conjunto com eles. Entusiasmaram-se com a ideia e, a partir de então, esse foi o tema da conversa. Durante algum tempo estivemos ali, trocando algumas ideias, os quatro, a respeito da educação bilíngue. Samuel mostrou-se afeito à ideia, salvo por algumas ironias que fazia ao afirmar que, depois da educação bilíngue, o índio viraria jurua e poderia ir viver na cidade, ou então que, em breve, todos estariam dizendo "bom dia", "boa tarde", "boa noite", e dando-se as mãos como jurua.

Durante a conversa sobre a educação, Samuel mostrou-se solícito e interessado, propondo um trabalho coletivo a ser realizado em breve. Suas opiniões, entretanto, eram bastante ambíguas, demonstrando sutilmente grande descrença em relação a todo esse processo.

A minha presença na área, normalmente, criava uma facilidade maior de locomoção para eles. A solicitação mais comum era que eu os conduzisse de carro para o hospital em São Sebastião ou em Bertioga para buscar ou levar algum parente ou eles próprios. Algumas vezes, era para que fossem fazer compras nesses mesmos centros. Outras poucas era para locomovê-los entre outras áreas - Bracuy, em Parati-RJ, Rio Branco, em Itanhaém-SP, ou Barragem, São Paulo-SP -, com objetivos diversos. A minha presença também facilitava o acesso a bens materiais, tanto com solicitações de compra quanto em pagamentos de dívidas nos armazéns próximos da área. As necessidades eram sempre comida, fumo, roupas, panelas e utensílios agrícolas.

Para eles, eu oscilava entre os dois polos, do amigo ao inimigo, quando esse caminho se tornava mais curto pela bebedeira da 
pinga branca que lhes embaçava a fome e o pensamento. Nesse momento, como inimigo, eu era severamente criticado em português, mas, como amigo que precisa aprender a língua e a maneira de ser do grupo, recebia as palavras que me eram ditas lenta e cuidadosamente. A hostilidade no convívio, nessas horas, diluía-se, entretanto, na participação mútua dos segredos, oferecidos em confiança. A língua, objeto inicial da pesquisa, ia sendo oferecida aos poucos, em todas as situações: das falas corriqueiras do dia claro aos mistérios noturnos de todas as origens.

Semelhantemente ao que já afirmaram Nimuendaju, Schaden e Cadogan, os Guarani do Ribeirão Silveira têm o ayvu como centro de suas concepções sobre o homem de maneira geral. O ayvu é, para eles, o próprio princípio regulador do homem. A criança nasce desprovida dele, adquire-o por ocasião do karai nome que dão ao ñeengarai de Nimuendaju - e deve mantê-lo sempre forte por meio da participação nos poraí - nome que dão ao que Schaden descreveu como porahêi —, produzindo-os e recebendo-os. Esse fortalecimento, entretanto, pode ser realizado de várias maneiras: pelo jeroký ('dança’), pela aspersão da fumaça de petynguá ('cachimbo'), pelo recebimento de poraí ('cantos') em sonhos ou nas ocasiões em que eles são apresentados, e pela aquisição de conhecimentos de natureza diversa, a partir de leituras, de viagens, de narrativas contadas, de sonhos, etc. Nesse caso, além da língua, o ayvu representa todo o poder de conhecimento do indivíduo. No Silveira, faz-se uma rígida distinção entre ayvu, que é "fala", e ñee, que é "voz" ou "som", que não possui sentido algum, é característico de animais e de objetos.

O fortalecimento do ayvu pela fumaça do cachimbo capacita, mais e mais, o indivíduo no uso da língua do grupo. Dessa maneira, as vezes em que eu sentia dificuldades em compreender a língua guarani, sugeriam-me que participasse mais amiúde dos poraí que realizavam. Nessas ocasiões, além da minha assistência passiva, 
realizavam, sobre minha cabeça, o que chamam motati, ou a aspersão de fumaça do petynguá. Então, diziam-me que só assim eu poderia aprender direito a língua.

Fato semelhante ocorria antes de se iniciar cada sessão de poraí. Entretanto, o objeto do motati, que poderiam ser as pessoas, era o maraká, no caso um violão de cinco cordas afinado em Sol. Quando perguntei por que faziam isso, disseram-me que o maraká, por ser um objeto, não pode falar - para o que usaram o termo "ayvu" - , portanto era preciso, toda vez, fazer motati. Quando ele era usado somente para marcar o ritmo do xondáro (dança masculina, na qual o homens que participam enfrentam-se ou fingem enfrentar-se, procurando derrubar um ao outro com golpes de ombro), o motati não era realizado. Nesse caso, o termo que usavam era "embopu", no sentido de "e-", imperativo, "mbo-", causativo, e "pu", 'som?

A participação de todos nos poraí é causa de grande preocupação na área. Embora haja duas aldeias, uma só oowaxú, que é a casa em que fazem as rezas, as reuniões, as danças e tudo o mais que seja de interesse comum do grupo, tem sido construída. No primeiro ano, o pajé Samuel vivia no Silveira, constantemente afastado da Boraceia. Por essa ocasião, construiu uma oowaxú. A aldeia da Boraceia ficara à margem das rezas que se realizavam. Com o recrudescimento do alcoolismo, que justificavam por esse afastamento, foi necessário que o pajé se transferisse para a Boraceia e, com ele, que se construísse uma oowaxú por lá.

A construção da oowaxú na Boraceia apresentou resultados surpreendentes. Com exceção dos casos crônicos de bebedeira, a maioria parecia ter encontrado um outro foco de interesse. Assim, realizavam-se muitas reuniões, ou aty waxu, pelos mais diversos motivos. Numa das vezes em que estive lá, pude assistir a uma sequência bastante intensa de encontros de todos os Guarani da área, envolvendo as duas aldeias e, também, de outras áreas. 
Tratava-se dos preparativos de festas que ocorreriam nas cidades de São Sebastião e Bertioga. O tema das festas era justamente o "Dia do Índio". Para isso, durante mais de duas semanas, toda a área preocupou-se em elaborar as "roupas de índio" que usariam nas apresentações. Eram tangas de palha, cocares de uma só pena disposta por trás da cabeça e pinturas com canetas "hidrocor" de várias cores por todo o corpo, sem seguir um padrão que eu conhecesse.

Entre esses preparativos, havia ininterruptamente atividades paralelas em andamento. Porque iriam apresentar suas danças tradicionais nessas comemorações do "Dia do Índio", treinavam-se as crianças em duas danças: o xondáro, para os meninos, e a xondária, para as meninas. Esta era conduzida pelas mulheres e aquela, pelos homens. Se a xondária era realizada a contragosto pelas meninas, do xondáro todos os homens participavam com gosto. Era uma dança que se iniciava logo pela manhã, no pátio em frente à oowaxú, e que se prolongava pela noite, quando então, entremeada pelos poraí de muitos dos homens, realizava-se dentro da casa.

Os ensaios persistiam durante a noite e eram combinados com discursos realizados pelos oporaíva, "cantores", mais fortes. Nessa ocasião, também as mulheres falaram. O teor das falas tanto era a respeito da maneira própria de ser guarani que eles iriam representar na cidade, quanto das responsabilidades dessa maneira de ser que se imputava a eles. Por mais de duas horas, as crianças, em pé, formando duas filas, uma de meninos, na frente, e outra de meninas, atrás, ouviram silenciosamente as diversas falas que se sucederam. À parte isso, os pajés realizavam motati durante todo o tempo sobre a cabeça das crianças. Quando eu perguntei por que faziam isso tantas vezes, disseram-me que era para que as palavras ficassem na cabeça das pessoas. Caso contrário, elas não se lembrariam mais do que foi dito. 
Caso semelhante ocorreu quando um dos que se esforça para ser um "grande pajé", como ele mesmo diz, contou que tem estudado muito para isso, mas que, às vezes, não consegue se lembrar do que leu, precisando participar mais dos poraí. Nesse caso específico, as leituras que tem realizado são sobre história do Brasil, sobretudo do período colonial, sobre os outros índios tupi-guarani e, particularmente, sobre os tupinambá. Na medida do possível, tenho tentado fornecer-lhe material para elas.

Os poraí a que assisti realizaram-se sempre no final da tarde dentro da oowaxu. O pajé (ou os pajés) logo assumia uma postura característica para a ocasião. Ligeiramente isolado de todos, fumava vigorosamente o cachimbo que lhe era preparado pela esposa. Quando havia mais de um pajé, cada um fumava um cachimbo, se houvesse vários, ou repartiam-nos entre todos, à maneira de chimarrão ou de tererê. Isto é, as mulheres preparavam o cachimbo com fumo de corda picado e entregavam a um deles, este fumava até consumir todo o fumo contido no fornilho e o devolvia. Experimentei fazê-lo algumas vezes, mas a fumaça quente e muito densa não me permitiu realizar sequer duas baforadas seguidas.

Guampas de erva mate acompanhavam o cachimbo, quando as havia, senão, bebia-se muita água e cuspia-se muito. Perguntei a função de ambos e soube que se deviam ao gosto ruim da nicotina (foi esse o termo usado), completando que seria bom se só viesse fumaça.

Durante esse período, aparentemente solene para os oporaíva, quando algum, de olhos fechados, dedilhava algumas melodias no maraká, fazendo motati sobre ele, para os demais, que vinham chegando e se acomodando, a situação era corriqueira e não exigia qualquer cuidado com os preparativos que estavam sendo realizados.

Quando havia vários pajés, muitas coisas poderiam ocorrer simultaneamente: um motati numa criança de um lado, a realização de um poraí de outro, e até mais de um. Entretanto, os oporaíva não se misturavam, nem perdiam a postura inicial. A aparência 
que se tinha era a de tratar-se de infusões individuais de "força mágica" (para usar a expressão de Nimuendaju), a partir da produção de fumaça pelo petynguá.

Durante essa preparação, o motati era realizado constantemente sobre algumas cabeças, escolhidas por algum motivo que não consegui descobrir. Algumas vezes foi sobre a minha também. Nas sessões de cura, a fumaça era aspergida sobre o corpo todo do paciente, em especial sobre alguma parte afetada. Conforme a doença, uma narrativa era recitada fortemente.

Para muitos, seus poraí não tinham letra, só melodia, via de regra, semelhante à melodia dos cantos dos pajés de maior prestígio. Estes, por sua vez, tinham cantos diversos, sempre com letra e muitas notas longas. Dos oporaíva pyau, como já os ouvi dizer ("pyau" é "novo"), ouvia-se um canto fraco e tímido; dos outros e, sobretudo, de Samuel, que já ouvi sendo chamado de Ñande ryke’y - "nosso irmão mais velho" e um dos deuses da teogonia guarani (cf. Schaden, 1989, p. 164, que afirma que "o pajé é um pequeno herói, como o herói é um grande pajé”) - e de Xamaé (que não sei o que significa), desses, pode-se ouvir o canto a grande distância. Durante sua execução, os cantores voltam-se para o ponto de onde primeiro se avista o sol, numa dança constante, em movimentos ora circulares, ora pendulares, com o maraká ininterruptamente sendo tocado, sempre no acorde básico em Sol de sua afinação. Nesse caso, apesar de melódico, o maraká mais se assemelha a um instrumento de percussão e de acompanhamento.

Após a realização dos poraí, todos vão de volta a suas casas, e alguns permanecem numa conversa que pode durar até a madrugada. Quando a oowaxú era na aldeia do Silveira, o pajé contava histórias que teriam ocorrido em tempo elocal indefinidos, geralmente com um primo, um conhecido inominado. As histórias eram geralmente sobre seres ou fatos maravilhosos: havia os "homens sem cu", que só tomavam sopa; os prédios de São Paulo, que 
caíram com o vento; a água do ribeirão Silveira, que, certa vez, subiu tanto, que era possível pescar de dentro da rede de dormir.

Outras vezes, essas histórias reproduziam-se em dia claro, a qualquer momento, de surpresa. Mas era inevitável que, ao chegar com um desconhecido, as histórias de onça, xiví, fossem contadas pelo pajé Samuel, com elas levando a pior: porque fugiram, porque morreram, mas sempre por conta do narrador.

Com referência à educação, na aldeia do Silveira, quando havia escola, com professor índio formado no Rio das Cobras, Paraná, pelo linguista do S.I.L., Robert Dooley, a prática que se realizava eram as leituras em conjunto com todas a crianças. Conforme pude assistir algumas vezes, o professor sentava-se em qualquer lugar, geralmente bem distante do prédio que fora construído para isso, e lia os textos para as crianças e, via de regra, para os adultos, que se aglomeravam em torno dele. $\mathrm{O}$ interesse era grande da parte de todos, que permaneciam nessa atividade até que as leituras terminassem. Como eram poucas, comumente eram repetidas. Algumas crianças já as conheciam de cor. Quando estas pegavam os livros, pareciam estar lendo, reproduzindo fielmente todos os movimentos do professor. Nesse caso, as demais crianças ficavam em torno da "leitora", ouvindo-a e corrigindo-a em alguns pontos.

Intrigado com essa prática que me era desconhecida, procurei verificar o que as crianças conseguiam ler. Quando eram palavras que não havia no texto conhecido, não sabiam ler, mas quando eram palavras que havia, sabiam. Os textos eram curtos, cinco ou seis linhas em letra de forma.

A mudança recente da oowaxú para a aldeia da Boraceia interrompeu esse processo, pois muitas famílias se mudaram para lá ou foram para outras áreas. Lá, as crianças frequentam a escola municipal, que se localiza próxima à área. Diariamente, um ônibus escolar entra na área para buscá-las e para trazê-las de volta. 
Várias tentativas de instalar uma escola na aldeia da Boraceia já foram realizadas, para as quais promessas de políticos locais, ofertas de material de construção, acordos e convênios de instituições diversas com a Funai ou diretamente com os índios, criaram muita expectativa que, na totalidade das vezes, se frustrou, entre eles. A imagem de "educação indígena" que se criou era bastante negativa, preferindo confiar no ônibus e na escola municipal.

Numa ocasião, convidaram-me para participar de uma aty waxu em que se discutiria a construção da escola. Após a apresentação, pelo Chefe de Posto, dos motivos da reunião, todos falaram. Eu procurei apresentar um projeto de educação diferenciada em língua guarani, isto é, mais um projeto de educação indígena que se diluía entre vários. A atenção de todos, entretanto, voltou-se para a construção do prédio da escola, que deveria ter luz elétrica, água encanada, banheiros e outros dados que inexistem na área. Em seguida, discutiu-se sobre a merenda. A decisão final foi a de aguardar a construção do prédio.

A questão da escola na área tornou-se, pois, um assunto que não mais poderia ser discutido. Entretanto, o acesso ao texto escrito continuou a ser solicitado veladamente. A escola municipal faz com que se confrontem com uma visão distinta daquela que conhecem, produzida na própria aldeia. Ela os atinge diretamente em sua maneira de ser e de falar, uma vez que o texto escrito em que se lhes propõe a educação oficial na língua portuguesa concorre, no dia a dia, com o seu próprio ayvu adquirido socialmente desde a infância.

Bakthin lembra que "a palavra nativa é percebida como um irmão, como uma roupa familiar, ou melhor, como a atmosfera na qual habitualmente se vive e se respira. Ela não apresenta nenhum mistério" (1981, p. 300). As crianças da escola municipal escrevem em português, e falam em português e em guarani correntemente. 
Em conversa que tive sobre esse tema, disseram-me "os moço e as moça, hoje, querem sair muito, por que vão à escola do branco, veem muita coisa nova e querem conhecer; então, eles saem e casam com branco, e não voltam mais; daí, não assiste mais porai e vira branco de uma vez" (Samuel). A educação desvinculada dos procedimentos religiosos realizados na aldeia é tomada como um fator de desagregação étnica. E é revelador que a manifestação do ayvu, a realização do motati, próprios das cerimônias guarani, reportam-se a uma metafísica especificamente guarani. Pode-se dizer que o ayvu guarani forma guaranis, não se permitindo universalizar como uma explicação do ser humano genérico.

Barth estabelece dois aspectos, a partir dos quais se devem as diferenças étnicas de grupos distintos:

(i) overt signals or signs - the diacritical features that peoples look for and exhibit to show identity, often such features as dress, language, house-form, or general style of life, and

(ii) basic value orientations: the standards of morality and excellence by which performance is judged. ${ }^{3}(1969$, p. 14)

Dessa maneira, é possível reconhecer a consciência de ambos os aspectos no comportamento guarani de Silveira. O primeiro - sinais abertos - ocorreu, claramente, quando dos preparativos para as comemorações do "Dia do Índio", em São Sebastião e Bertioga. Nessa ocasião, procuraram "vestir-se" conforme a imagem de índio que a população regional esperava ver. $\mathrm{O}$ segundo valores básicos de orientação, de moralidade e excelência - pode ser notado no confronto entre o modo guarani de aprender e o da

3 "(i) sinais ou signos manifestos - traços diacríticos que as pessoas procuram exibir para demonstrar sua identidade, tais como vestuário, língua, arquitetura ou estilo de vida, e (ii) valores básicos de orientação: padrões de moralidade de excelência pelos quais seu desempenho é julgado." (Tradução do autor) 
escola municipal, isto é, em ambos, preconiza-se o conhecimento, mas, no caso guarani, ele decorre da contribuição individual entre os membros do grupo e atua no sentido de defender o indivíduo, física e moralmente, do que possa ameaçá-lo; no caso da escola municipal, o conhecimento não se reparte entre todos e advém de uma única fonte e atua somente no sentido de capacitar o indivíduo para o mercado de trabalho do "branco".

Barth afirma, a esse respeito, que os traços culturais que sinalizam a fronteira e as características culturais dos membros podem se transformar, sem que tal transformação acarrete uma perda de identidade (1969, p. 14). Nesse caso, a alfabetização caminha pelo mesmo viés, independentemente da língua de sua realização. Conforme já se viu, se a língua é um dos sinais abertos, pode-se substituir por outros, conquanto que se mantenha como sinal diferenciador. Barth afirma, ainda, que a persistência de grupos étnicos em contato implica não só critérios e sinais para identificação, mas também uma estrutura de interação que permite a persistência das diferenças culturais (BARTH, 1969, p. 16). Nesse último caso, o fator que ameaça a persistência das diferenças culturais, segundo pude conhecer, é a individualização dos conhecimentos e a exclusividade das fontes.

Dessa maneira, qualquer tentativa de incorporar a alfabetização às práticas tradicionais de transmissão de conhecimento guaranis deverá, necessariamente, considerar que todo conhecimento precisa ser compartilhado a partir de contribuições individuais. A exclusividade do conhecimento e de formas de transmissão desfiguraria as manifestações dos oporaíva de seu sentido tradicional, isto é, poderiam ser tomadas não como uma possibilidade de repartir a experiência pessoal de cada um com o grupo, mas como uma cristalização folclórica de "crendices". Os "valores básicos de orientação, padrões de moralidade e excelência pelos quais o desempenho é julgado" tornar-se-iam "traços diacríticos que as pessoas procuram exibir para demonstrar sua identidade". 
Muito embora esse procedimento não impeça o grupo de estabelecer sua identidade étnica valendo-se de outros recursos, pode-se imaginar que as tentativas ocorrerão a partir das fontes de conhecimento que concorriam com as tradicionais. Nesse caso, além do conhecimento adquirido da sociedade regional com a qual tem grande familiaridade, também o conhecimento adquirido na escola contribuirá para a formação dessa identidade. Os "valores" e os "padrões" assim adquiridos, seja por empréstimo, seja por imposição, resultarão na impossibilidade de auto-regulamentação do grupo. Os mecanismos tradicionais de controle e de avaliação das condutas estarão sujeitos a uma ingerência externa, como é o caso de chamar-se a polícia até em casos de violência conjugal. Fatos como esse denunciam que o próprio grupo já não se considera mais capaz de resolver seus problemas internos sem recorrer a outros grupos, particularmente a sociedade nacional. É de se esperar, pois, que, nesse processo de transformação, outras formas de ingerência dessa sociedade em assuntos guaranis passem a ocorrer com maior frequência e magnitude.

A alfabetização, nesse caso como subproduto da escola que esteja para além do domínio guarani, ao contrário de atuar para manter e fortalecer a identidade do grupo, terá atuado no sentido de homogeneizar grupos diferenciados e de extinguir a diversidade cultural. Se, de um lado, o conhecimento gerado por fontes diversas é reinterpretado individualmente e devolvido com essas contribuições sociais, mantendo o grupo coeso, mas dinamicamente transformado; de outro lado, na educação escolar municipal, o conhecimento gerado por uma única fonte não se permite reinterpretar, senão pela mesma fonte, mantendo o grupo coeso, pelo compartilhar da informação, mas doentiamente estático pela impossibilidade de conduzir seus próprios pensamentos. 


\section{Alfabetização e formas de pensamento}

Cassirer conceitua o pensamento teórico-discursivo a partir de sua capacidade de isolar seus conteúdos da experiência sensível. Trata-se mais especificamente da capacidade de abstração lógica e conceitual, que estabelece categorias controladas e controláveis para os fatos, desde o estabelecimento de igualdades e diferenças. No caso do pensamento discursivo, o homem, numa atitude contemplativa, afasta-se da realidade, da qual emerge, para, analítica e sinteticamente, extrair dela ideias e leis gerais, das quais cada individualidade não é senão um de seus exemplos previsíveis, ou seja, "o fato aparentemente singular e conhecido é fixado num conceito, mas só quando é 'submerso' numa ideia geral, quando é aceito como o 'caso' de uma lei, como membro de uma multiplicidade ou de uma série" (CASSIRER, 1976, p. 41).

O pensamento mítico, entretanto, ele o conceitua a partir de seu contato intensificado com a realidade circunstancial do homem. Segundo o próprio Cassirer (1976), desse ponto de vista, "a realidade externa não é simplesmente vista e contemplada, mas se impõe ao homem na sua crua imediatez, causando emoções de medo ou de esperança, de terror ou de desejos satisfeitos e libertos..." (p. 61). O pensamento mítico, portanto, é o que estabelece a relação homem-mundo e elimina a mediação asséptica do racionalismo: "assenta-se na realidade imediata e só conhece esta presença sensível, que o toma e o subjuga pelas intuições" (CASSIRER, 1976, p. 60).

Dessa maneira, ao contrário do pensamento teórico-discursivo, o pensamento mítico não se interpõe ao homem e à natureza, mas realiza-se a partir da relação íntima que se estabeleceu entre eles. 
Às duas formas de pensar, relacionam-se diferentemente as palavras. No primeiro caso, a palavra é o signo arbitrário, construído conscientemente pela mente humana para fins específicos. Cassirer assim a define:

a palavra [...] se interpõe, por assim dizer, entre as reais impressões particulares, tal como se dão no imediato aqui e agora; e justamente essa interposição, este sobressair da esfera dos dados imediatos, é o que confere essa liberdade e agilidade, que lhe permite mover-se entre os objetos específicos e coordená-los entre si. (1976, p. 98)

No segundo caso, a palavra é o signo não arbitrário, mas intrinsecamente ligado a seu próprio referente. Entre o nome e a coisa nominada, estabelece-se uma relação metonímica que sugere ser cada palavra muito mais um signo icônico do que o signo simbólico gerado pelo pensamento discursivo. Peirce considera o ícone como a representação pela semelhança (1975, p. 116). Portanto, se o nome é parte da coisa, reproduzir o nome é estabelecer uma metonímia capaz de evocar o todo, no qual o referente se constitui.

No pensamento mítico, ainda que o referente não esteja ao alcance dos sentidos, a palavra que o representava permanece ligada à memória e virtualmente realizável pelo fato concreto de sua enunciação. Isso permite a própria atualização do referente desaparecido. A esse respeito, Cassirer ainda afirma que, para o pensamento mítico, "só tem significado de existência aquilo que se lhe apresenta na sua realidade tangível imediata; aqui não interessa o simples 'referir' ou 'significar', antes, todo o conteúdo da consciência, para o qual tende e intenciona a mente, é transformado imediatamente numa forma de presença real e efetiva” (1976, p. 98).

A palavra, então, desse ponto de vista, pode ser tomada como um fluir espontâneo, inerente à própria natureza das coisas a que se refere. As relações arbitrárias entre o plano de expressão 
e o de conteúdo transformam-se em vínculos obrigatórios capazes de gerar um ao outro pela sua simples presença, ou seja, se o signo linguístico é arbitrário na teoria, não o é na prática.

No curso de Saussure, lembra-se que "nenhuma sociedade conhece nem jamais conheceu a língua de outro modo que não fosse como um produto de gerações anteriores e que cumpre receber como tal" (1977, p. 85-86). Com certeza, a língua a que se refere este trecho é a língua materna, adquirida quase inconscientemente desde a infância e que parece uma atividade tão natural como "andar e pouco menos do que respirar" (SAPIR, 1971, p. 17).

Bakhtin verificou diferenças significativas entre língua materna e língua estrangeira. Aquela, ele disse que "é percebida como um irmão, como uma roupa familiar, ou melhor, como a atmosfera na qual habitualmente se vive e se respira. Ela não apresenta nenhum segredo" (1981, p. 100). A língua estrangeira, entretanto, ele associou às línguas mortas:

\begin{abstract}
Uma língua morta apresenta-se claramente como uma língua estrangeira para o linguista que a estuda. Por isso é impossível afirmar que o sistema das categorias linguísticas constitui o produto da reflexão epistemológica do locutor de um a língua dada. Não se trata de uma reflexão sobre a percepção que o locutor nativo tem de sua própria língua: trata-se, antes, da reflexão de uma consciência que luta para abrir caminho no mundo misterioso de uma língua estrangeira. (BАKHTIN, 1981, p. 98)
\end{abstract}

Ele continua seu raciocínio estabelecendo, ainda, uma nova analogia, que é a da língua morta-escrita-estrangeira (BAKHTIN, 1981, p. 99). Essa língua, críptica por sua própria natureza, resulta de um processo de reflexão consciente sobre um dado materialmente insensível à primeira vista, mas ao qual é possível aproximar-se para atingi-lo pela reflexão: 


\section{Os Índios e a Alfabetização}

Na língua materna, isto é, precisamente para os membros de uma comunidade linguística dada, o sinal e o reconhecimento estão dialeticamente apagados. No processo de assimilação de uma língua estrangeira, sente-se a "sinalidade" e o reconhecimento, que não foram ainda dominados: a língua ainda não se tornou língua. (BАКнтіN, 1981, p. 94)

Para Bakhtin, portanto, a língua só se permite organizar como sistema se, paradoxalmente, for críptica e desconhecida, isto é, ainda não servir para os propósitos básicos de quaisquer atividades humanas de linguagem. $\mathrm{O}$ falante nativo, segundo ele, não tem consciência da materialidade do sistema. Para o falante, sua língua materna é formada só de ideias, só de emoções:

não são palavras que pronunciamos ou escutamos, mas verdades ou mentiras, coisas boas ou más, importantes ou triviais, agradáveis ou desagradáveis. (p. 95)

A língua materna, entretanto, pode transformar-se em língua estrangeira ou em língua morta, bastando para isso considerá-la pelo mesmo ponto de vista; como o faz o linguista, que "estuda as línguas vivas como se fossem mortas e a língua nativa como se fosse estrangeira" (BAKHTIN, 1981, p. 105). O afastamento provocado pelo racionalismo permite essa metamorfose, pois, como ele ainda afirma, "configurando o sistema da língua e tratando as línguas vivas como se fossem mortas e estrangeiras, o objetivismo abstrato coloca a língua fora da comunicação verbal" (BAKHTIN, 1981, p. 107).

Esse mecanismo de suspensão, produz-se pelo "objetivismo abstrato", que se assemelha demasiado ao que Cassirer chamou de pensamento discursivo. Impõe-se, pois, uma analogia primária entre a língua materna e o pensamento mítico, de um lado, e, de outro, entre a língua morta-escrita-estrangeira e o pensamento discursivo. Bakhtin considerou, no primeiro caso, que "o sentido da 
palavra é totalmente determinado por seu contexto" e, no segundo, que "a língua, como sistema de formas que remetem a uma norma, não passa de uma abstração, que só pode ser demonstrada no plano teórico e prático do ponto de vista do deciframento de uma língua morta e do seu ensino" (BAKhtin, 1981, p. 104, 108).

Scribner e Cole lembraram que há três formas tradicionais para se classificar a transmissão de conhecimento entre gerações de grupos étnicos: a educação informal, a educação formal em ambientes não institucionais e a educação formal da escola (1973, p. 554). A propósito da educação escolar eles disseram:

\begin{abstract}
we can provisionally define formal education as any process of cultural transmission that is (i) organized deliberately to fulfill the specific purpose of transmission, (ii) extracted from the manifold of daily life placed in a special setting and carried aut accordin to specific routines, and (iii) made the responsibility of the larger social group. ${ }^{4}$ (SCRIBNER; COLE, 1973, p. 555)
\end{abstract}

Dos três aspectos básicos dessa definição, é de ressaltar-se o item (ii), que estabelece que a educação escolar seja "extraída de cópias da vida diária e localizada num ambiente especial". Esse fato, necessariamente, implica isolar o próprio educando do meio no qual terá de inserir-se tão logo esteja preparado para isso. Extrair "cópias da vida diária", por sua vez, implica aprender por simulação do contexto; a escola recria a natureza e a sociedade e as relações que se estabelecem entre elas. $\mathrm{O}$ ambiente especial da escola forma-se de cenários diversos em que todos simulam papéis provisórios e arbitrários que desaparecem tão logo se abandone esse ambiente.

\footnotetext{
4 "podemos definir, provisoriamente, a educação formal como qualquer processo de transmissão cultural que é (i) organizado deliberadamente para cumprir o propósito específico da transmissão, (iii) extraído de aspectos da vida cotidiana e colocada em uma configuração especial que se realiza de acordo com rotinas específicas, e (iii) feito sob a responsabilidade do grupo social mais abrangente." (Tradução do autor)
} 
A educação informal é a transmissão de conhecimentos pela vida diária, em que não há ambiente especial nem simulações da realidade:

Such education is called informal because it occurs in the course of mundane adult activities in which the young take part according to their abilities. There is no activity set aside solely to "educate the child". Social processes and institutions are structured to permit the child's acquisition of the basic skills, values, attitudes, and customs which defifne appropriate adult behavior in the culture. ${ }^{5}$ (SCRIBNER; COLE, 1973, p. 555-556)

A educação informal não simula a natureza nem a sociedade, como já disse, mas, ao contrário, ocorre justamente da interação entre elas e o educando. Os resultados obtidos em cada prática educacional, ou os papéis estabelecidos durante o mesmo processo, não se permitirão abandonar e deverão perdurar como conquistas de habilidade e de personalidade já a partir do momento em que ocorreram.

A educação formal em ambiente não institucionalizado, segundo Scribner e Cole, não se consegue diferenciar com clareza da educação informal. Pela exiguidade de dados descritivos desse tipo de educação, que tinham naquele momento, abandonaram sua análise, questionando apenas se ela é simplesmente uma extensão dos meios de aprendizagem no curso da vida diária ou se apresenta "algo novo" (1973, p. 555). Seria, pois, uma forma intermediária entre a educação escolar e a informal, tendo-se em vista diferir da

\footnotetext{
5 “Tal educação é chamada de informal porque ela ocorre no curso cotidiano das atividades adultas das quais os jovens participam de acordo com suas habilidades. Não há uma atividade reservada apenas para 'educação das crinças' de maneira a permitir a aquisição das competências, valores, atitudes e costumes básicos que definem o comportamento adulto apropriado na cultura." (Tradução do autor)
} 
educação escolar apenas por não se realizar a partir de "cópias da realidade". Nesse tipo de educação, em que se formaria um pajé, por exemplo, não se pode simular a formação de um pajé, ou a realização de uma cura: uma vez instaurado o processo, não se pode retrocedê-lo.

Nesse caso, é possível tomar educação escolar e educação informal como formas básicas de transmissão do conhecimento. Novamente, é possível, também, estabelecer-se analogia entre essas formas e o uso diferenciado da língua que se faz em ambas. Scribner e Cole salientaram:

Children and adults are always learning through the medium of language, outside the school as well as in it. What is special about the school situation is that there language becomes almost the exclusive means of exchanging information. ${ }^{6}$ (1973, p. 556)

No ambiente escolar, em que o predomínio é o da simulação, a recriação necessita realizar-se pelos meios próprios para isso. A partir de signos provisórios, cuja arbitrariedade será notável pelo mero abandono da ligação entre as partes que os constituem, é forçoso prever-se o predomínio obrigatório do signo simbólico nesses ambientes, em que a própria língua materna será tomada como tal. Scriber e Cole citaram como exemplo as dificuldades enfrentadas por voluntários de Peace Corps quando, numa sala de aula, tinham de dizer que $\mathrm{x}+4=7$, se já haviam dito que $\mathrm{x}+5=10$ (1973, p. 558). Uma infinidade de exemplos de frases utilizadas em sala de aula, cujo sentido não tem nenhum valor pragmático, poderia ser levantado a partir de livros didáticos, corroborando com a posição de Bakhtin a esse respeito:

6 "Crianças e adultos estão sempre aprendendo por meio da linguagem, dentro e fora da escola. O que é especial sobre a situação da escola é que existe lá a línguagem torna-se praticamente o meio exclusivo de troca de informação." (Tradução do autor) 


\section{Os Índios e a Alfabetização}

Originada no processo de aquisição de uma língua estrangeira num propósito de investigação científica, a reflexão linguística serviu também a outros propósitos, não mais de pesquisa, mas de ensino; não se trata mais de decifrar uma língua, mas, uma vez essa língua decifrada, de ensiná-la. As inscrições extraídas de documentos heurísticos transformam-se em exemplos escolares, em clássicos da língua. (1981, p. 99)

Novamente, dissociam-se língua e realidade, o que, conforme já se pôde ver, ocorria na palavra do pensamento discursivo. A escola é o local do pensamento discursivo por excelência; é o ambiente em que a palavra definitivamente se distancia de sua carga referencial, permanecendo como código capaz de simular funções de linguagem, sem exercê-las de fato. Scribner e Cole afirmam a esse respeito:

A substantial part of school learning may be seen as the process of becoming competent in the use of various symbol systems of this kind. A great deal of attention is devoted to teaching the child new techniques for processing information (how to read, to write, to "figure", for example) which mediate later learning. ${ }^{\top}(1973$, p. 557)

Torna-se clara a ênfase que recai sobre o código. No caso da fala, a língua materna terá de perder seu vínculo com a realidade circunstancial, para tornar-se um jogo de sinais, cujas regras foram definidas a partir do estabelecimento das categorias controladas e controláveis e da extração de leis gerais do pensamento teórico-discursivo. Scribner e Cole assim ilustraram a educação escolar:

\footnotetext{
7 "Uma parte substancial da aprendizagem escolar pode ser vista como o processo de tornar-se competente no uso de vários sistemas de símbolos dessa natureza. Uma grande parte da atenção é dedicada ao ensino de novas técnicas de processamente de informação (como ler, 'figurar', por exemplo) que vão intermediar o aprendizado posterior.' (Tradução do autor)
} 
This tendency to treat a wide class of problems as examples of some general class or rule es an excellent example of what we have been referring to as a functional learning system. ${ }^{8}$ (1973, p. 557)

A educação escolar deve, portanto, isolar-se da língua materna enquanto veículo condutor só de ideias e de emoções, cuja materialidade não se permite apreender senão após tratá-la como fosse um código desconhecido. Para a escola, as palavras não podem ater-se de maneira definitiva a seu próprio referente, senão por uma ligação tênue entre ela e a coisa nominada. Estabelecem-se os valores a partir de padrões determinados ad hoc, e apenas como simulações, incompatíveis com a concretude da realidade sensível dos educandos, em que os nomes e as coisas confundem-se num único todo, desde muito antes do momento de sua enunciação. E esse todo, bem como suas partes, se permitem explicar apenas por um discurso alheio ao racionalismo abstrato da educação escolar. Nesse discurso não há representação possível, pois a palavra é ela própria o fato que se imaginaria representar, seus valores são absolutos $a b$ origine. Muito embora categorizações diversas se verifiquem, segundo os falantes, elas apenas acompanham os fatos categorizados e não resultam de operações complexas de análises e de sínteses da realidade. São herdadas prontas, como o afirmou Saussure, e assim permanecem, sofrendo alterações apenas no curso de sua história.

O processo alfabetizatório a que se submete um grupo, para o qual a palavra é a fala espontânea e imaterial, cujos signos icônicos evocam por si só seu referente, pressupõe a consciência do sinal e de suas normas específicas de uso. Para essa passagem, da ausência de escrita até a alfabetização, Ferreiro e Teberosky (1980, p. 241 e ss.) definiram cinco etapas distintas e sucessivas.

8 "Essa tendência para o tratamento de uma larga classe de problemas com exemplos de alguma classe ou regra geral é um excelente exemplo do que nós estamos referindo como um sistema de aprendizagem funcional." (Tradução do autor) 
$\mathrm{Na}$ primeira etapa, a criança reproduz o que identifica como forma básica da escritura.

Si esta forma básica es la escritura de imprenta, tendremos grafismos separados entre sí, compuestos de líneas curvas y rectas o de combinaciones entre ambas. Si la forma básica es la cursiva, tendremos grafismos ligados entre si, con una línea ondulada como forma de base, en la cual se insertan curvas cerradas o semicerradas. (1980, p. 241)

e, ainda, "la correspondencia se establece entre aspectos cuantificables del objeto y aspectos cuantificables de la escritura". Nessa primeira etapa do desenvolvimento cognitivo da aquisição da escrita, a criança formula hipótese, partindo de um conhecimento anterior, ou de experiências com textos escritos, procurando extrair traços materiais que lhe pareçam os mais significativos de sua experiência. Assim, ela constrói diversas possibilidades de escrita, que poderiam ser diagramáticas, ideográficas, hieroglíficas, etc., capazes de permitir a recuperação de ideias, de falas ou de sons, a partir de um texto grafado.

$\mathrm{Na}$ segunda etapa, a criança condiciona variações de fala com variações gráficas, estabelecendo limites para a escrita: um número mínimo de símbolos, ou uma quantidade fixa de sinais gráficos para representar algo - palavras de quatro letras, por exemplo. Se as hipóteses na etapa anterior poderiam oscilar entre correspondências de imagem, como a se prever uma escrita hieroglífica, nesse caso a criança parece optar por uma correspondência mais diagramática, que varia entre a imitação das escritas que conhece e a referência do que procura escrever.

$\mathrm{Na}$ terceira etapa, a criança procura estabelecer que cada sílaba esteja relacionada com cada sinal gráfico, mantendo, sempre, os condicionamentos das etapas anteriores. Pode-se pensar que, desde esse nível, a criança já estabeleceu como será o sistema de escrita, isto é, sinais gráficos que representam sons da fala. 
$\mathrm{Na}$ quarta etapa, "el niño abandona la hipótesis silábica y descubre la necesidad de hacer un análisis que vaya "más allá" de la sílaba por el conflicto entre la hipótesis silábica y la exigência de cantidad minina de grafias". Durante as duas primeiras etapas e em parte da terceira, a criança raciocinou a partir de suas próprias hipóteses. Nessa quarta etapa, imbricada na terceira, ela passa a valer-se de informações que ultrapassam os limites de sua experiência com a escrita, isto é, ela verifica que a escrita não se explica por si mesma e, definitivamente, a palavra não permite encontrar nela própria o seu conteúdo, passando de uma escrita natural, cujos valores são intrínsecos, para uma escrita cultural, cujos valores são extrínsecos e definidos arbitrariamente.

$\mathrm{Na}$ quinta etapa, a criança compreende, afinal, o sistema alfabético da escrita e já está apta para compreender as idiossincrasias da ortografia de cada língua tomada individualmente.

Em todo esse processo, verifica-se a passagem de uma concepção icônica para uma concepção simbólica da escrita. Aos poucos, a criança abandona as correspondências entre o signo e o seu referente, atentando mais e mais para o sinal de sua própria língua. Da forma gráfica que representava, à maneira de diagrama, para a forma simbólica, cuja relação semiótica a criança só consegue depreender a partir da informação fornecida por agentes específicos, tais como pais e professores, a aquisição da escrita vem acompanhada de um treino sistemático, proporcionado tanto pelo contato diário com textos diversos, a partir dos quais ela extrai os modelos de suas hipóteses, quanto pelo seu tratamento específico em atividades pré-alfabetizatórias orientadas nesse sentido.

Tanto o treino pelas atividades específicas, quanto pelo contato diário com a escrita parecem ser os responsáveis pela continuidade desse processo. Ainda Ferreiro e Teberosky reportaram-se a essa questão quando compararam o desenvolvimento da aquisição da escrita por crianças de classe média, cujos pais tinham nível superior 
de escolaridade, e haviam fornecido educação pré-escolar a seus filhos, e por crianças da comumente denominada classe baixa, cujos pais não possuíam o mesmo grau de instrução nem forneceram educação pré-escolar a seus filhos.

Los datos de los niños de CB son completamente diferentes: sí bien a los 4 años están muy próximos a los de CM, desde los 5 años la diferencias son marcadas: ningún sujeto de CB supera el nível 3; más aún, el grupo de 6 años presenta un regresión con respecto al grupo de 5 años. Dos razones principales nos parecen dar cuenta de esta regresión: por una parte, el hecho ya señalado que la mayoría de los niños de 6 a. CB no habían asistido previamente a jardín de infantes; por otra parte, el hecho que por razones ajenas a nuestra voluntad no nos fue posible tener más de una entrevista con estos niños, en quienes el bloqueo masivo frente a cualquier situación de tinte escolar es la normas. (1980, p. 284)

Muito embora as autoras coloquem em dúvida a representatividade dos dados que coletaram em relação às crianças de 6 anos, é de se notar que as diferenças entre as crianças de classe baixa e as de classe média ocorrem sobretudo na passagem do nível 3 para o nível 4, ou seja, da hipótese silábica para a escrita alfabética propriamente dita. Conforme a sequência de raciocínio que se pretende para essa questão, trata-se especialmente do momento em que a criança requer informações externas para cotejar com suas hipóteses prévias, estabelecidas desde as etapas anteriores. A princípio, suas informações eram obtidas de sua própria experiência no trato com a escrita, a partir da observação da escrita e dos atos de leitura e da busca, entre eles e/ou entre a escrita e os sentidos da leitura, de semelhanças capazes de apontar para os processos de transformação da fala em escrita e vice-versa. A seguir, entretanto, quando as analogias já não se bastavam por si só, a criança tinha de encontrar informações a partir de outras fontes, para além de 
suas próprias intuições. Nesse último caso, fossem os pais ou a escola propriamente dita, essa etapa teria de se cumprir dessa maneira.

As crianças de classe baixa, que não receberam treinamentos pré-alfabetizatórios, tiveram seu desenvolvimento abortado justamente na passagem da escrita icônica para a escrita simbólica, quando tiveram de abandonar suas intuições para receber um treinamento mais racionalizado, em que a língua se codifica e o sinal parece suplantar o sentido. Nessa etapa, ocorre a instrumentalização da língua como um sistema manipulável, ou, como disseram Scribner e Cole, mais atrás, "uma técnica para processar informações".

A familiaridade com a escrita permeia, pois, todo o processo de sua aquisição. Assim, a criança necessita, a um só tempo, da educação informal e da escolar. Aquela para formular suas hipóteses e esta para conduzi-las a um ponto específico de chegada. É possível que, para outros sistemas de escrita, seu desenvolvimento ocorra por meio de outras etapas, mas, a se considerar a escrita alfabética ocidental, é pouco provável que elas venham a diferir radicalmente dessas que Ferreiro e Teberosky descreveram.

A partir da quinta e última etapa descrita, a criança já está apta a conhecer uma ortografia específica e a considerá-la como um "caso" da escrita alfabética em geral, bem como a alfabética como um "caso" dentre as outras formas de escrita possíveis. Durante todo o processo alfabetizatório, terá sido, pois, esse o percurso do raciocínio da criança: estabelecer hipóteses e testá-las, primeiro, a partir das formulações intuitivas, que lhe determinaram a busca de semelhanças, depois, a partir de regras e arbitrariedades que lhes são fornecidas desde um código já estabelecido, cujo acesso só lhe será permitido pelas informações exógenas de pais e de educadores.

Kato verificou que a passagem da escrita icônica para a simbólica apresenta "um estreito paralelismo entre as fases da história da escrita e as fases de desenvolvimento da criança em relação a esse objeto" (1990, p. 9). Muito embora os vínculos entre os 
desenvolvimentos "filogenético" e "ontogenético" não se tenham explicitado, a autora chamou a atenção para o fato de que entre ambos poderia haver mais do que simples coincidência.

Lévi-Strauss, entretanto, ao tratar dessa questão, considerou que estabelecer etapas para o desenvolvimento de uma sociedade, tal como é possível estabelecer para o indivíduo, faz tábula rasa do passado que todas as sociedades têm atrás de si, "aproximadamente da mesma ordem de grandeza” (1989, p. 35). Dessa maneira, a escrita alfabética deveria ter-se desenvolvido, aliás de forma imperiosa, em todas as sociedades, uma vez que a extensão do passado é "aproximadamente da mesma ordem de grandeza" para todas. Lévi-Strauss afirmou:

\footnotetext{
Para considerar determinadas sociedades como "etapas" do desenvolvimento de outras, seria preciso admitir que enquanto com estas últimas se passava qualquer coisa, com aquelas não acontecia nada, ou muito pouca coisa. [...]. Durante dezenas e mesmo centenas de milênios, também nelas existiram homens que amaram, odiaram, sofreram, inventaram, combateram. Na verdade, não existem povos crianças, todos são adultos, mesmo aqueles que não tiveram diário de infância e de adolescência. (1989, p. 35)
}

Assim, descartada a hipótese biogenética para o desenvolvimento da escrita, será necessário buscar outra justificativa para a semelhança atestada por Kato (1990). Nas etapas descritas por Ferreiro e Teberosky, parece claro que a consciência da materialidade da língua, tomada pelo código e não pela referencialidade, é um elemento fundamental. Nesse caso, a natureza do código condiciona o sentido da elaboração de uma grafia para ele.

Goodman lembrou que, "apesar de que as formas escritas das línguas possam relacionar-se com a forma oral da mesma língua de modos diferentes, todas devem plenamente representar 
o significado de alguma maneira compreensível que não depende de convertê-lo em sua contrapartida oral. Algumas usam escrita alfabética. Algumas não representam as vogais. Algumas usam símbolos para representar sílabas. Algumas representam ideias diretamente" (1990, p. 13). É de se notar que, malgrado a diversidade, qualquer que seja o sistema de escrita selecionado, alguma relação ele haverá de manter com a língua, portanto, haverá de ser necessariamente uma escrita icônica.

Grosso modo, seria possível verificar que a escrita ora pende para o referente, ora pende para o código. Nas etapas iniciais descritas por Ferreiro e Teberosky, o padrão gráfico era definido pelo padrão de escrita conhecido pela criança, mas elementos para a incorporação do referente na grafia apareciam para complementar a representação. Por exemplo:

una niña mexicana de 5 años, llamada Verónica, escribe su nombre así: VERO; pero piensa que cuando sea grande lo va a escribir "con la ve grande" (es decir BERO, ya que en México la V es llamada "be chica" y la B es la "be grande"). (1980, p. 243)

A experiência da criança com o texto escrito limita o rol de possibilidades para o desenvolvimento da escrita. Sempre que solicitada a manifestar-se sobre isso, procura recolher de sua experiência modelos gráficos capazes de representar a fala. Desse ponto de vista, fica mais claro que a criança volta-se para dois focos: os padrões de grafia conhecidos e a natureza do código a ser representado.

A propósito dessa natureza, Sapir considerou que a palavra deve ser considerada como uma unidade de sentido e uma realidade psicológica conhecida por qualquer falante: 


\section{Os Índios e a Alfabetização}

Não pode haver prova mais convincente do que a seguinte: o índio, ingênuo e completamente despercebido do conceito da palavra escrita, não tem apesar disso dificuldade séria em ditar um texto a um investigador linguístico, palavra por palavra; propende, naturalmente, a ligá-las entre si, à maneira da enunciação oral, mas, se chamado à pausa e feito compreender o que dele se pretende, isolará, imediatamente, os vocábulos como tais, repetindo-os sob forma de unidades. (1971, p. 44)

É de se esperar que, pela consciência do falante, uma palavra se deixe representar por um sinal gráfico, ou por sílabas, como bem o explicita Ladefoged:

It seems that everybody finds syllabs to be comparatively easy units to identify. But people who have not been educated in an alphabetic writing system find it much more difficult to considerer syllabs as being made up of segments (consonants and vowels). ${ }^{9}(1989$, p. $219-220)$

Sob outro ponto de vista, Jakobson já chamou a atenção para outro aspecto da língua que permite ser representado diagramaticamente:

Verifica-se a existência de um nítido caráter diagramático não somente na combinação de palavras em grupos sintáticos, mas também na combinação de morfemas em palavras. Tanto na sintaxe como na morfologia, qualquer relação entre as partes do todo se conforma com a definição que Peirce dá dos diagramas e de sua natureza icônica. (s.d., p. 107-108)

9 "Parece que todo mundo entende que sílabas sejam unidades fáceis de serem identificadas. Mas pessoas que não foram educadas num sistema de escrita alfabética acham muito mais difícil considerar sílabas como sendo compostas de segmentos (consoantes e vogais)." (Tradução do autor) 
Para ilustrar esse raciocínio, ele relaciona tanto analogias entre sons e o referente, do tipo father, mother e brother, quanto analogias entre o tamanho do nome e da coisa nominada: altus, altior e altissimus (JAKoBson, s.d., p. 108, 111), em que a quantidade de sílabas aumenta conforme aumenta a altura do objeto adjetivado.

A partir disso, é possível verificar que a própria natureza da língua oferece modelos para sua representação, tomados das ideias, das palavras, das sílabas e, até, dos fonemas, como ainda propõe Sapir:

En el curso de una larga experiência en la notación y análisis de lenguas no escritas, indo-americanas o africanas, he llegado a reunir pruebas concretas sobre el hecho de que el sujeto que habla, cuando es poco instruido, no oye elementos fonéticos, sino fonêmicos. (1947, p. 162)

As hipóteses que a criança formula sobre a natureza da escrita tomam por base seu próprio conhecimento linguístico. A sequência dessas formulações, definidas como "etapas" ou "níveis", ocorre no sentido de uma análise cada vez mais detalhada dos elementos do código. Ao tratar de unidades menores e menos aparentes, a atenção do falante para o seu próprio código intensifica-se, pressupondo uma intensificação de mesma ordem na atividade metalinguística, qual seja a de contemplar, analisar e comparar o sinal da língua, extraída ela própria de seu contexto, numa simulação de uso que permite sua manipulação.

A observação da língua materna, desse ponto de vista, estabelece novas relações entre ela e o falante, que a toma por objeto material, quase manipulável com as próprias mãos, por meio de suportes físicos capazes de forjarem articulações: do conhecimento intuitivo de igualdades passa-se para uma constatação visível, no caso específico da escrita alfabética, pela manipulação das letras. Para as demais formas de escrita, ainda que diferentes, é de se supor que permitam alguma manipulação dessa natureza. 
A alfabetização como prática da educação formal insere-se num contexto mais amplo de forma de pensamento, muito embora não se confunda com ela. O raciocínio dedutivo é formado a partir de operações como essas realizadas bastante amiúde no ambiente escolar - a aprendizagem de códigos a que Scribner e Cole se reportaram. Uma experiência particular que tive na colaboração em dois cursos de formação de professores índios - Waiãpi, na Serra do Navio-AP - permitiu-me atestar esse fato.

O propósito inicial de minha participação nesses cursos era dar subsídios teóricos para o desenvolvimento de uma grafia da língua waiãpi, a partir de necessidades apresentadas pelos próprios alunos. O trabalho metalinguístico planejado baseava-se em tentativas de se suscitarem as dificuldades no registro escrito da língua Waiãpi, que se apresentariam em exercícios de transcrições de narrativas e descrições curtas, gravadas pelos próprios alunos. Essa atividade seria uma continuação dos trabalhos realizados anteriormente, no primeiro semestre de 1992, quando, em curso semelhante, igualmente com a minha participação, tentou-se provocar o interesse pelo uso escrito da língua Waiãpi.

Desde o curso anterior, entretanto, foi grande a oposição a quaisquer atividades numa modalidade escrita da língua tradicional do grupo. As opiniões claramente manifestas, sobretudo pelos alunos que retornavam à Serra do Navio para tomar parte nesses trabalhos, contrariavam novamente nossas expectativas quanto ao desejo de usar a língua Waiãpi tanto para simples registro dos nomes de artesanato, quanto para atuar como forma de comunicação entre os próprios colegas de curso. Os argumentos contrários aos nossos propósitos fundavam-se sobre três pontos principais: (i) não havia nenhuma espécie de acordo entre os falantes quanto a qualquer padronização de grafia para a língua, na medida em que tal procedimento fazia tábula rasa das diferenças dialetais tradicionais, (ii) tanto o estudo da língua quanto seu ensino eram realizados 
por professores que não a falavam como língua materna, provocando grande variedade de distorções em todos os níveis linguísticos (fonético, morfológico, sintático, semântico, discursivo), que terminariam por imprimir uma diversidade indesejável de fala no grupo, e (iii) só o conhecimento mais aprofundado da língua portuguesa, escrita e falada, poderia contribuir para uma interação mais equilibrada entre o grupo Waiãpi e as sociedades regional e nacional.

Embora um dos líderes do grupo, Kasiripiná, houvesse discutido com os alunos e determinado que os trabalhos com a escrita na língua Waiãpi devessem ter continuidade, a argumentação contrária foi fortemente defendida pelos chefes Kumai e Kumaré, os quais estiveram de passagem no curso, nos dias que sucederam a saída de Kasiripiná. Tendo em vista essa situação, transformei os propósitos iniciais que tinha para atuar junto dos alunos, a fim de que fosse possível atender melhor os interesses do grupo.

Assim, do trabalho com a língua Waiãpi passei para o trabalho com a língua portuguesa, nas suas modalidades escrita e falada, tomando por base narrativas orais e interpretação de textos escritos originalmente na língua portuguesa. A atividade de produção de narrativas orais constava de, após a narrativa realizada em português pelo aluno, uma sequência de perguntas e respostas que visava a torná-los mais hábeis no uso das formas linguísticas do português (o tempo e o aspecto verbais, o sentido das preposições, a variação de número nos nomes e sua concordância, entre outras). A atividade de interpretação de textos escritos era praticamente a mesma, diferenciando-se, apenas, quanto ao fato de que os textos não eram produzidos por eles, mas aproveitavam-se os materiais que dispunha para isso: o Livro de Mapas Waiãpi, principalmente, e alguns textos escritos por Moropi, um dos alunos do curso, quando estivera em São Paulo, devidamente corrigidos. Em vista de o Livro de Mapas conter textos escritos por falantes nativos do português, 
além da iminência da demarcação da A.I. Waiãpi, foi dada preferência para a leitura e para a interpretação completas desse livro.

Muito embora as dificuldades iniciais tivessem sido grandes para esse tipo de atividade, especialmente no que diz respeito às perguntas que se faziam após cada leitura ou narrativa, os alunos mostraram-se bastante interessados nesses exercícios e puderam apresentar um domínio crescente do tipo de linguagem que se devia usar para tais casos. Assim, se inicialmente não sabiam como responder o que era um "divisor de águas" ou onde se poderia encontrar o "leste" nos mapas, ainda que soubessem o que significava, após alguns dias em que exercícios análogos eram praticados, eles já apresentavam um domínio manifesto para esse tipo de resposta. Da mesma maneira, as descrições por analogia, como "a árvore do urucum é como o cajueiro", logo passaram a ser realizadas por comparações de grandezas pré-estabelecidas: "a árvore do urucum é da mesma altura que a do caju".

Tais fatos mostraram que as formas de raciocínio dedutivo, com as quais eles teriam de lidar nos processos de interação com as sociedades nacional e regional, necessitariam ser praticadas mais amiúde, para que os alunos pudessem ampliar seu domínio sobre elas. Assim, no decorrer das aulas, paralelamente às atividades de treino do uso da língua portuguesa falada, procurei desenvolver atividades classificatórias, que envolvessem constantes categorizações e re-categorizações de objetos com os quais eles estivessem habituados ao manejo.

A primeira tentativa que se fez foi com a manipulação de formas geométricas com tamanhos e cores diferentes. No princípio, à semelhança dos exercícios que envolviam perguntas e respostas, tiveram dificuldade na compreensão daquilo que desejei que realizassem: a expectativa era que eu lhes oferecesse as categorias prontas para que, então, eles só tivessem de distribuir os objetos entre elas. Não ficara claro o fato de que eles próprios tinham de 
estabelecer as categorias em que os objetos seriam distribuídos. A solução para o impasse surgiu por meio de insight que me esforçava por provocar em todos eles. A partir do insight de um, provocado quer pela minha realização, na frente deles, das tarefas solicitadas, à maneira da educação informal, quer pela solicitação de respostas a perguntas que envolviam as categorizações propostas, logo os demais conseguiram reproduzi-lo.

Embora as categorizações e re-categorizações fossem produzidas com facilidade no caso específico das figuras geométricas - fato esse compreensível, em virtude do número das variáveis controladas ser bastante restrito, como forma, cor e tamanho o insight não se mantinha ao se tentar transportá-lo para outras atividades de categorização de objetos. A primeira atividade que se realizou foi tentar que estabelecessem classes de artesanato, a fim de possibilitar a fixação de preços para as peças. Os primeiros resultados dessa atividade, entretanto, ficaram bastante aquém daquele que se esperava, primeiro, porque os alunos não queriam superpor um "nome" de categoria ao nome tradicional de cada peça, segundo, quando aceitavam a superposição, as categorias estabelecidas não se mantinham fixas, à medida que os critérios variavam de peça para peça. Finalmente, ao se obter uma categorização definitiva, após um dificultoso insight ter sido provocado entre os alunos, os objetos foram distribuídos entre categorias funcionais, que poderiam ser utilizadas para a fixação de uma tabela de preços.

Os processos cognitivos de aprendizagem por insight para o raciocínio dedutivo, apesar de mostrarem-se extremamente eficazes para a compreensão das propostas de trabalhos que seriam apresentados, não se mantinham de uma tarefa para outra. Assim, segundo eles, as unidades de medida pré-estabelecidas usadas, por exemplo, para a comparação entre o comprimento de tecidos que seriam comprados não se poderiam aplicar na comparação entre árvores, ou, as classes de objetos artesanais waiãpi fixadas 
não serviam para a sua venda efetiva. Nesses casos, o domínio das categorizações não permanecia para além da sala de aula, deixando-os à mercê dos critérios que eram oferecidos pelos outros.

Ao ter por alvo promover o maior conhecimento da língua portuguesa por parte dos alunos, a fim de que não só pudessem interagir em pé de igualdade com as sociedades regional e nacional, mas também que, como professores, soubessem transmitir esse conhecimento a seus alunos, verificou-se que o desenvolvimento dessa forma específica de raciocínio, paralela às suas próprias, era imprescindível, mas não se conseguiria alcançar a partir somente de insight provocado. Um treino metódico e continuado necessitava ser realizado, pelo menos, a médio prazo para que se pudesse alcançar o domínio dessa técnica de depreensão de critérios de categorização para quaisquer objetos.

O longo período de um ano e meio, ou quase isso, entre o primeiro curso e o segundo curso, foi demasiado longo para que se pudesse notar a permanência de conhecimentos dessa natureza nos alunos que frequentaram ambos os cursos. O maior domínio de práticas mecânicas, tais como leitura e contagem, entretanto, pôde ser facilmente verificado, ao que parece, devido a uma participação mais sistemática dos alunos em aulas ministradas na própria área indígena durante esse período. Assim, se considerarmos, semelhantemente a essas práticas mecânicas de leitura e de contagem, as técnicas de depreensão de critérios de categorização como um fenômeno passível de treino para o seu completo domínio - traço fundamental do raciocínio dedutivo que se procurou transmitir-lhes —, é possível induzir que apenas a instalação de um processo educacional metódico voltado para esse propósito, dentre outros, garantiria a manutenção e o desenvolvimento dessa habilidade cognitiva.

Esse fato foi verificado quando atividades diárias que envolvessem depreensão de critérios classificatórios eram continuadamente realizadas. A leitura do Livro de Mapas Waiãpi 
possibilitou, por exemplo, já no final da semana, a compreensão de que todos os desenhos de mapas eram realizados de tal maneira que a parte superior sempre representava o Norte, o lado direito representava o Leste, o esquerdo Oeste, e assim por diante; portanto, com superposição de categorias, estabelecidas ad hoc, e não como características intrinsecamente próprias de cada objeto. A princípio não havia como mostrar-lhes que o Norte e a parte superior de um mapa não eram a mesma coisa, mas que, tão somente, essa representava aquela, em qualquer outro mapa. Quando se solicitava que mostrassem, no mapa, o limite norte da A.I.Waiãpi, eles não sabiam onde encontrá-lo, embora reconhecessem bem os limites desenhados. Mas, quando se solicitava que mostrassem o Norte no desenho, logo eles apontavam a parte superior do mapa. Como se lhes parecesse que "Norte" e "parte superior do desenho" eram expressões sinônimas e não categorias distintas para apreciação de um mesmo objeto, a realização da tarefa que lhe propunha ficava bastante dificultosa. Assim, a partir de insight provocado e após uma repetição constante dessa atividade com todos os mapas do livro durante alguns dias, eles se mostraram hábeis o suficiente para dominarem o manuseio dos mapas e do vocabulário correspondente.

Do conjunto de fatos que se pôde verificar no decorrer desse curso, a se tomar por base o questionamento dos Waiãpi a propósito do uso de sua língua para restabelecer relações para objetos de uso tradicional, foi possível perceber que não era possível desvincular "nome" e "coisa nominada". Após alguma constância desse procedimento com exemplos na língua portuguesa, os falantes permitiram-se abandonar uma forma de pensamento para assumir, provisoriamente, outra.

Rey, quando analisou a fala de camponesas analfabetas no sul da Espanha, verificou que 


\section{Os Índios e a Alfabetização}

[...] tan pronto se producen variaciones o se altera la homologia e identidad entre el orden simbólico y la práctica activa por razones de cambios ecológicos, o processos de difusión y de aculturación, las condiciones sistemáticas resultantes pueden requerir ajustes en estos sistemas de complementaridad y oposición. Esto significa que, a partir de unas condiciones tecno-económicas e ideológicas que desarrollan nuevas prácticas y reglas en la asignación de roles-estatus sexo-sociales, se pueden modificar los mitos y ritos para hacerlos consistentes con un nuevo esquema simbólico, o con el mismo reformulado. [...] Así, por ejemplo, a partir del momento en que las mujeres desarrollan una consciencia de grupo sexual militante y tienen acceso a posiciones más semejantes a las del hombre, se producen las condiciones para que las relaciones de oposición pasen a ser de contradición, y con ello se superen dialécticamente las asimetrías y los mitos tradicionales que las justifican. (1988, p. 79-80)

O fato de se assumirem novos papéis, numa outra cultura, permite a observação do mundo por um novo ponto de vista. A língua portuguesa, nesse caso, permite ser tratada dessa maneira. O nome das coisas pode variar nessa língua, ou, para retomar o exemplo referido por Scribner e Cole, " $\mathrm{x}$ " pode valer 3 ou 5 , conforme o momento. O conhecimento e a manipulação de uma língua estrangeira, às vezes nem tão estrangeira, devidamente sustentado por uma conversão material para sua abordagem, no caso a escrita, permitem estabelecer novos critérios para sua análise e manipulação, eventualmente, transponíveis para sua própria língua.

Como consequência de tudo o que já se disse, é possível estabelecerem-se dois grandes grupos. O primeiro, sob o rótulo de "pensamento mítico", engloba a língua materna, a aprendizagem informal, a relação não arbitrária entre o nome e a coisa referida, as primeiras etapas do processo de aquisição da escrita, dentre outras. O segundo, sob o rótulo de "pensamento discursivo", 
engloba as línguas estrangeiras, a aprendizagem escolar, a arbitrariedade do signo, a simulação da realidade, etc. Grosso modo, é de se pensar que, ao se propor uma "escola" ou uma "educação" indígena ou para o indígena ou pelo indígena, etc., haver-se-ia de reunir ambas as formas de pensamento num mesmo ambiente, distribuídas entre professores e alunos, de modo que estes se dispusessem a praticar a discursiva, ou parte dela.

\subsection{O pensamento guarani}

Entre os Guarani do Ribeirão Silveira, é possível verificar-se a predominância praticamente absoluta do pensamento mítico. Desde as primeiras relações que se estabelecem com estranhos que são levados à área, até as relações que se mantêm entre os próprios membros do grupo, existe a identificação das histórias que conhecem e os fatos que ocorrem.

A desconfiança e o acanhamento notáveis nessas primeiras relações vinculam-se mais especificamente à produção e à transmissão de conhecimentos próprios do grupo. Estender-se em longas conversas com desconhecidos resultaria em deixá-los apropriar-se de suas especificidades e, eventualmente, de sua própria identidade, isto é, estar-se-ia permitindo ao desconhecido "guaranizar-se". Por outro lado, ao ser introduzido no grupo por intermédio de um membro do próprio grupo ou de algum conhecido, cujas diferenças étnicas já se estabeleceram com nitidez, o "acanhamento" e a "desconfiança" se permitem transformar numa apresentação formal da origem das diferenças. Dessa maneira, o relatar das histórias de onça, a xivi, não só apresenta a origem direta de ñane rykey, mas também define sua relação com o "outro", para o qual as onças existem apenas no zoológico e nos livros com sua presença iminente sendo sempre temida e assustadora. 
O fato de se ter consciência do risco dessa transmissão de conhecimento, ou de sua necessidade como uma forma de apresentação, por exemplo, implica igualmente o seu domínio. Entre os Guarani do Ribeirão Silveira, muito embora a educação seja informal, ela é praticada intencionalmente. As histórias narradas pelos cantos são selecionadas pelos momentos específicos de sua realização. Determinadas presenças na oowaxu, por ocasião dos porai, refletem-se em cantos específicos, concordes com as necessidades do momento. A presença de crianças que vão à escola, de pessoas que estão pela primeira vez na aldeia, ou de viagem iminente que se estão por fazer, etc., envolvem conhecimentos próprios que devem ser transmitidos.

A cestaria artesanal guarani, conhecida já por sua excelência, tão logo alguém mostre aptidão para confeccioná-la, os mais hábeis se apressam para, ao lado do principiante, realizar seus trançados lenta e visivelmente, a fim de apresentar as técnicas utilizadas, ou, ao contrário, havendo alguma rivalidade, evitam realizá-los frente a eles. O mesmo cuidado ocorre nas plantações, no manuseio, na construção de casas, na confecção e mistura de farinhas para fazer pão e em várias outras habilidades próprias da vida do grupo.

O acesso a habilidades desconhecidas, entretanto, como já se disse, nem sempre se transmite da mesma maneira, mas, ao contrário, termina por ser de domínio exclusivo de indivíduos determinados. Via de regra, são conhecimentos adquiridos informalmente junto da sociedade regional e/ou formalmente durante algum período em atividades escolares. Se, no primeiro caso, trata-se de uma forma de contato virtualmente acessível a todos, no segundo, há determinadas condições que definem seu público de acesso.

A Lei 5692/71 fixa que "o ensino de $1^{\circ}$ e $2^{\circ}$ Graus tem por objetivo geral proporcionar ao educando a formação necessária ao desenvolvimento de suas potencialidades como elemento de 
auto-realização, preparação para o trabalho e para o exercício consciente da cidadania”. A escola volta-se especificamente para crianças brasileiras, monolíngues na língua portuguesa, e que se imagina terem os ideais comuns de ascensão social por meio do acúmulo de conhecimentos e do enriquecimento econômico pelo "trabalho honesto". As habilidades cognitivas que se procuram desenvolver nessas escolas voltam-se, pois, para uma criança ideal bastante diferenciada da criança ideal guarani. Os adultos são naturalmente eliminados desse acesso. Quando há cursos noturnos de alfabetização, o aluno ideal pressuposto para frequentá-los difere pouco ou nada daquele que se descreveu para as crianças.

O interesse na aquisição dos conhecimentos transmitidos pela escola, atestado desde a chegada dos primeiros jesuítas ao Brasil, permanece; mesmo que, para alcançá-los, os Guarani tenham de submeter-se a um tratamento culturalmente espoliativo, ao serem considerados como o seu próprio "outro".

A transmissão informal do conhecimento realizada coletivamente no interior da aldeia precisa, portanto, cumprir a dupla função de manter a coesão do grupo com seu passado e de salvaguardar essa mesma coesão do risco de mudanças abruptas promovidas pelo contato com a sociedade nacional.

Conforme já se disse, a educação informal ocorre na interação entre a sociedade e o educando. Disso se depreende que a presença do "aluno" no seu próprio meio é fundamental para sua manutenção, coisa que tem sido notadamente manifesta entre os Guarani, no que diz respeito à participação de todos nos porai. A educação formal, entretanto, é, por sua natureza, para ser realizada em ambiente específico, por meio de rotinas de ensino/aprendizagem próprias e pela simulação da realidade, tal como descreveram Scribner e Cole. Além disso, ela se desenvolve pelo tratamento da língua materna como língua estrangeira, completamente desvinculada da vida diária e do conhecimento tradicional do grupo. 
Ao se tomar a escola em conjunto com a sociedade nacional brasileira e com sua fração regional, é possível considerá-la como agente homogeneizador da diversidade cultural, sobretudo por seus propósitos de promover ascensão social, como fosse uma consequência direta da participação de suas atividades. Sob esse ponto de vista, a escola forma para integrar o indivíduo na sociedade nacional brasileira, o que contraria a formação da pessoa guarani, necessariamente não brasileira. A esse respeito, é de se ressaltar o desconforto e, às vezes, a irritação por um questionário linguístico que elaborei, no qual, para verificar a oposição entre ore e ñane, solicitei que me traduzissem "nós somos guarani” e "nós somos brasileiros". Essa última expressão não foi traduzida, por ter sido considerada imprópria e, inclusive, ofensiva para muitos.

Apesar do caráter integrador da escola municipal, é inegável que ela atua satisfatoriamente em relação ao treino de habilidades cognitivas próprias do pensamento discursivo, estas de interesse para os Guarani; tratando-se principalmente da alfabetização, da matemática, da geografia e da história. Esse fato era marcante desde o primeiro contato que tive com os meninos, quando, fora da casa, contavam os pontos do jogo com bolas de gude, e mesmo na construção das casas, quando eram frequentemente solicitados a contarem o madeirame do telhado, ou tirarem suas medidas. Igualmente para as leituras de preços nos armazéns ou do itinerário dos ônibus, os mesmos meninos eram constantemente solicitados.

A educação escolar municipal, entretanto, condiciona essas habilidades a um projeto de pessoa que vai de encontro com o modo de ser guarani. Este pressupõe o desenvolvimento de seu próprio domínio por intermédio de uma aquisição cada vez maior de conhecimentos, a serem distribuídos entre os demais membros do grupo. Essa aquisição, para ser eficaz, não se dá por si só, mas necessita acompanhar-se da participação nos porai, a fim de que, pelo motati, seu ayvu possa incorporar o novo conhecimento e, a 
partir dele, ser transmitido a todos em outros porai. O indivíduo guarani não ascende socialmente pela riqueza de bens acumulados, mas pela quantidade maior de conhecimentos que podem ser usados em benefício de todos. Dessa maneira, o líder do grupo pode ser, e geralmente é, o melhor oporaíva, porque, a partir dele, são gerados todos os porai e todas as curas, mas também pode ser o que melhor consegue relacionar-se com a sociedade regional, para tirar dela o máximo proveito para o grupo.

Assim, os Guarani têm o fito na aquisição de habilidades cognitivas ainda mais isoladas do contexto nacional brasileiro do que a escola municipal tem condições de oferecer. Desprovida de seus fins mais genéricos, a escola terminaria por tornar-se a sua própria negação, pois seria uma escola sem conteúdos, bons ou maus: uma sequência de treinamentos em jogos simbólicos abstratos que não manteriam qualquer relação com a realidade. É de se notar que, embora os contextos culturais variem, a escola precisa engajar-se necessariamente no contexto em que se insere.

Para o caso guarani, conceber que uma escola venha a substituir a sua própria formação étnica é superestimar a eficácia do ensino formal escolarizado. Conforme foi possível verificar, as comunidades indígenas suplantaram todas as medidas "integracionistas", "salvacionistas" e "civilizadoras" que foram tentadas por meio da escola. O exemplo atual dos Borôro permite atestar que a educação formal não atinge o ethos grupal, que se mantém coeso e fiel às suas tradições, variando apenas pelas necessidades adaptativas do grupo que se transforma sem perder sua identidade (NovaEs, 1990).

Entretanto, o acesso à educação informal parece imprescindível para que o indivíduo permaneça integrado ao grupo. Nesse caso, é de se prever que o ambiente específico dessa forma de educação mantenha-se íntegro e capaz de reproduzir todas as condições necessárias para ela. No caso guarani, trata-se propriamente da 
permanência do indivíduo na aldeia, da frequência aos porai, da participação nas construções de casas, da confecção de artesanato, da coleta de palmito, das formas endógenas de casamento, do conhecimento da língua guarani, das migrações entre diversas aldeias, etc. Fumar cachimbo e cuspir, muito embora não seja um comportamento obrigatório, é um indício de que uma criança começa a configurar-se como todos os demais, por exemplo. Esse conjunto de traços culturais transmissíveis pela vida diária dá forma ao grupo e garante sua continuidade no tempo e no espaço, porque vincula-se ao próprio grupo desde os tempos da criação, o que explica e justifica tudo em todos os detalhes.

Extrair um traço desse conjunto, para tratá-lo à maneira de jogo simbólico abstrato, como se faz na escola com a língua, com a matemática, com a geografia, por exemplo, pressuporia poder tratá-lo desvinculadamente de suas origens e das relações íntimas que mantém com os demais traços compartilhados pelo grupo. Assim, o uso da língua tradicional, no contexto da aprendizagem formal, condicionaria seu uso a esses jogos simbólicos escolares. Se, para os Guarani, a fala e o indivíduo não se permitem tomar separadamente de seu contexto de enunciação, o uso dessa língua na escola teria necessariamente de isolar desse contexto a língua, o indivíduo, o referente e, talvez, a própria enunciação.

Como já se viu, a escola é o espaço próprio do pensamente discursivo e da língua estrangeira. Esta, por sua vez, não se vincula às origens do grupo nem se submete a relações com os traços culturais guaranis. Ela é apenas um dos jogos simbólicos escolares, uma simulação de fala, que eventualmente pode ser usada com a sociedade nacional e regional. Desde cedo todos têm acesso a ela como um instrumento necessário para esse trato, mas ela própria não se torna um conhecimento a ser distribuído entre todos porque é apenas o meio para se alcançar um benefício e não o próprio benefício. 
Adquirida como segunda língua, ainda que precocemente, a língua portuguesa não se confunde com a língua materna tradicional, tal como a definiu Wald:

a referência à mãe é um traço cultural e não estrutural da consciência unitária do repertório linguístico que a noção de língua materna induz. A evocação da mãe remete, aqui, à representação imaginária de uma forma de expressão original: a imagem de uma fala livre de qualquer coerção da enunciação e anterior a qualquer categorização. Em outros contextos culturais, será a referência ao nascimento, ao clã, ao torrão, aos ancestrais, ou a qualquer outro termo que representa as origens, que servirá de suporte a esta ideia, ao colocar em jogo o fato de existir uma linguagem e não apenas uma imagem da língua. (1989, p. 105)

Educação formal e educação informal realizam-se distintamente em ambientes específicos. Ainda que esta possa prescindir daquela, o conhecimento escolar pode ser complementar ao conhecimento transmitido no interior do grupo, sem causar prejuízo à coesão étnica e às formas tradicionais de pensamento que recobrem todas as atividades dos indivíduos, na Silveira e na Boraceia. Ao contrário, ao se tentar formalizar traços desse comportamento, como no caso da língua, corre-se o risco já alertado por Gnerre:

o modelo de língua escrita que é a assumido, em geral, é aquele da modalidade expressiva das línguas europeias que, [...] fica mais longe das modalidades e gêneros expressivos próprios da oralidade. Desta forma realiza-se o tipo talvez mais sutil de dominação: a de chegar a convencer os dominados de que sua língua pode (e deve) ser utilizada à imagem e semelhança dos dominadores. [...] A tentativa é a de transferir para a língua nativa, de tradição oral, as macromodalidades discursivas encravadas em algumas variedades escritas e em alguns gêneros 


\section{Os Índios e a Alfabetização}

comunicativos elaborados através dos séculos em algumas línguas europeias, e também o desejo ou a ilusão de codificar o mundo na forma mais “exata” possível. (1991, p. 108-109)

Nesse caso, será fundamental estabelecer-se que os ambientes de uso próprios de cada uma dessas línguas definam as suas formas de pensamento, a fim de se evitar que a língua materna se torne um arremedo da língua portuguesa, alheia às necessidades de seus falantes e padronizada conforme propósitos diversos de seu grupo de origem.

\subsection{Bilinguismo e educação formal entre os Guarani}

Fishman (1980), ao estabelecer o conceito de di-ethnia como contrapartida étnica da diglossia, isto é, a institucionalização social do biculturismo, por sua vez, contrapartida do bilinguismo, chamou a atenção para o fato de que seu aparecimento e manutenção estão condicionados a ambientes de usos específicos e complementares.

Two sets of cultural behaviours and identities must be in complementary distribution and strongly compartimentalized, as must be their language usages counterparts, if they are to constitute something more transitional arrangements. ${ }^{10}$ (Fishman, 1980, p. 11)

A formação de uma escola em que não se confundam traços específicos do pensamento discursivo com os do pensamento mítico vem ao encontro da complementaridade presente na noção

10 "Dois conjuntos de identidades e comportamentos culturais precisam estar em distribuição complementar e fortemente compartimentalizados, da mesma maneira que o uso das suas línguas, caso constituam mais do que arranjos de transição." (Tradução do autor) 
de di-ethnia proposta por Fishman. Ferguson (1959) descreveu um vínculo bastante estreito entre a variante/língua (cf. FISHMAN, 1967) e a educação formal. Na definição que apresentou para "diglossia", reportou-se à variante $\mathrm{H}$ como:

[...] higly codified (often grammatically more complex) superposed variety, the vehicle of a large and respected body of written literature, either of an earlier period or in another speech community, which is learned largely by formal education and is used for most written and formal spoken purposes but is not used by any sector of the community for ordinaty conversation..$^{11}$ (Ferguson, 1959, p. 336)

Muito embora seja possível questionar a "maior complexidade" dessa variante/língua, o uso diferenciado de língua, como no caso dos Guarani, de H (High) na escola e de L (Low) fora dela ou entre Guaranis, implicaria no estabelecimento das condições para o que Fishman chamou de bilinguismo com diglossia:

\section{[...] a fairly large and complex community in which the members have available to them both a range of compatimentalized roles as well ready acces to these roles. ${ }^{12}$ (1967, p. 32, grifos do autor)}

Assim, para os distintos papéis determinados pela comunidade, distribuem-se suas próprias línguas. Os padrões comportamentais desses papéis envolveriam, pois, a própria língua utilizada.

\footnotetext{
11 "uma variedade superposta, altamente codificada (e com frequência gramaticalmente mais complexa), veículo de um largo e respeitado corpo de literatura escrita, tanto de períodos mais antigos, quanto de outras comunidades, que é aprendida pela educação formal e usada para muitos propósitos escritos e de fala formal, mas não é usada por nenhum setor da comunidade para conversação ordinária." (Tradução do autor)

12 "Uma comunidade grande e complexa em que os membros têm a sua disposição tanto uma gama de papéis compartimentalizados como acesso imediato a esses papéis. (Tradução do autor.)
} 
Ao extrapolar para a identificação desses papéis sociais com etnias diferenciadas, que deveriam coexistir num mesmo grupo étnico, o que poderia parecer incoerente, Fishman (1980) cuidou de dizer que tais fatos são realmente raros, mas podem ocorrer quando há um apoio institucionalizado para isso, determinado a partir da própria comunidade:

Thus, just as no speech community can maintain two languages on a stable basis (past three generations) if they are both used in the same social functions and, therefore, stable societal bilingualism (diglossia) depends on institutionally protected functional sociolinguistic compartmentalization, so no ethnocultural collectivity can maintain two cultures on a stable basis past three generations if they are both implemented in the same social functions (family, friendship, word, education, religion, etc.), and therefore, stable societal multiculturism (di-ethnia) depends on institutionally protected ethnocultural compartmentalization..$^{13}$ (p. 13)

Ao se tomar a escola como um espaço institucionalizado requerido pelo próprio grupo, é possível imaginar-se que uma situação de diglossia e de di-ethnia poderia formar-se, de maneira a não comprometer a especificidade étnica. O grupo, como um todo, teria acesso ao pensamento discursivo, quando e como desejasse, a partir dos instrumentos comuns da educação formal. Fishman, ainda, salientou dois fatos que poderiam estabilizar uma situação de biculturalismo:

13 Assim como nenhuma comunidade de fala pode manter duas línguas sobre uma base estável (apos três gerações) se ambas a línguas forem usadas nas mesmas funções sociais e, portanto, um biliguismo social estável (diglossia) depend de uma compartimentalização sociolinguística funcional protegida; nenhuma coletividade pode manter duas culturas sobre uma base estável nas mesmas funções sociais (família, círculo de amigos, educação, religião, etc.) e portanto, depende de uma compartimentalizasção etnocultural institucionalmente protegida. (Tradução do autor), 
a) not integrating the two cultures involved but by keeping them separate, in a state of tension vis-a-vis each other, i.e, compartmentalization is recognized as necessary so that the outside world will not intrude upon [...] the "inner world": and

b) not accepting or implementing "the other culture" in its entirety but, rather, implementing it selectively and in a particular domain so as to keep it in complementary distribution with their "owm"H-governed and L-governed. ${ }^{14}$ (1980, p. 12-13, grifos do autor)

Chamam à atenção (i) a necessidade de se manter um estado de tensão entre os grupos em contato, (ii) a não intromissão externa na vida do grupo, (iii) a seleção dos itens a serem introduzidos e (iv) a distribuição deles nos domínio $\mathrm{H}$ e L, determinados pelo próprio grupo.

Uma situação de tensão étnica na fronteira entre os Guarani, e talvez a maioria dos grupos indígenas no Brasil, e a sociedade nacional brasileira é bastante evidente e pode ser verificada na maior parte da literatura etnológica e indigenista voltada para essa questão. Tem sido, aliás, a tônica das propostas de educação indígena no país.

O segundo item reporta-se especificamente à maturidade que deve ser alcançada pela sociedade nacional para conviver com o estado de tensão referido. Dumont reportou-se a essa maturidade quando, ao tentar compreender o sistema de casta da Índia, alertou seus prováveis leitores:

14 “a) não integrarem-se as duas culturas envolvidas, mas manterem-se separadas ou em estado de tensão vis-a-via, ou seja, a compartimentalização é reconhecida como necessária para que o mundo exterior não se intrometa no 'mundo interior' e

b) não aceitar ou não implementar a 'outra cultura' em sua totalidade, mas, implementá-la seletivamente e em um domínio particular de modo a mantê-la em distribuição com seus próprios H-governados e L-governados." (Tradução do autor) 


\section{Os Índios e a Alfabetização}

Entende-se que o leitor pode recusar-se a sair de seus próprios valores, pode afirmar que para ele o homem começa com a Declaração dos Direitos do Homem e condenar pura e simplesmente o que se afasta dela. Ao fazê-lo, ele com certeza marca estreitos limites para si, e sua pretensão de ser "moderno" fica sujeita a discussão não apenas de fato mas também de direito. Na realidade, não se trata aqui, digamo-lo de maneira clara, de atacar os valores modernos direta nem sinuosamente. Eles nos parecem, aliás, suficientemente garantidos para que tenham algo a temer em nossas pesquisas. Trata-se apenas de uma tentativa de apreender intelectualmente outros valores. (1992, p. 50, grifos do autor)

O princípio básico da não interferência, como forma de se deixar ser, pode vir a atingir os tabus mais bem estabelecidos da sociedade nacional, por exemplo, escravidão, machismo, infanticídio, racismo, suicídio coletivo, dentre muitos que se conhece ou que se conhecerá. A insistência na "conscientização pela escola", ou a "alfabetização na língua materna", se rejeitada pelo grupo alvo desses propósitos, fere justamente esse ponto que permite ao grupo salvaguardar-se dos deslocamentos indevidos de papéis, que resultariam na destruição da compartimentalização preconizada por Fishman.

No caso do item (iii), a seleção realizada pelo próprio grupo indica a perfeita consciência da institucionalização necessária para a complementaridade na distribuição das formas de pensamento entre as atividades. A alfabetização na escola, segundo os padrões que eles reconheceram como necessários, na língua que lhes pareceu mais adequada para isso, constituem o conjunto (pelo menos no caso da escrita) dos traços selecionados da etnia com a qual fazem fronteira e desejam estabelecer algumas trocas.

O último item, por sua vez, é justamente a distribuição dos traços adquiridos nos papéis que lhes convêm. 
Seja como for, a participação da sociedade nacional, ainda que na sua parcela mais bem intencionada no sentido de garantir a co-existência desses grupos, deve limitar-se ao fornecimento dos traços requeridos. Muito embora, pela reflexão crítica própria do pensamento discursivo, possa-se vir a suspeitar de um desastre étnico iminente, cuja causa acredita-se que seja o comportamento do grupo, será a própria diversidade étnica a advertência da inadequação de valores projetados e desejados para a cultura do outro. 


\section{Considerações finais}

Ao se considerar a educação escolar como um traço cultural tomado de empréstimo pelos Guarani, o que corresponde aos desejos manifestos pelo grupo, é possível verificar-se que tal fato não representa qualquer ameaça à sua identidade tradicional. $\mathrm{A}$ escola, nesse caso, deve ser compreendida, em seu conjunto, apenas como um instrumento capaz de fornecer-lhes as técnicas necessárias para o trato com a sociedade nacional brasileira.

Circunscrita ao seu próprio ambiente físico, a escola leva no bojo o pensamento discursivo, a escrita, a matemática, a geografia, a história, além de outros temas que lhe são próprios. No seu exterior, entretanto, vão suas contrapartidas específicas do mito e da educação informal.

A mediação entre o grupo e a sociedade nacional não se faz pela escola. Para aquela, o espaço é outro. Aquém dessas fronteiras, situa-se a escola, sob o domínio completo da população que a tomou de empréstimo. Mas, nos limites do grupo, onde, segundo Lévi-Strauss, "para vastas facções da espécie humana", "acaba a humanidade" (1989, p. 21), e o homem se torna o "outro", apenas apreensível intelectualmente, os resultados da educação escolar poderão ser verificados.

No trato com a população regional, ou com os "poderosos" de Brasília, ou com os advogados dos empresários encastelados em suas empresas, os Guarani estarão sujeitos a seus próprios conhecimentos, sem que haja qualquer mediação possível. Numa situação como essa, terão de dominar duas identidades: a sua própria e a do outro. A primeira, aos olhos do outro, garantirá a 
diferença, a segunda, indicará as estratégias a serem estabelecidas para obter-se o necessário.

É a partir dessa interação que o grupo, e somente ele, poderá conhecer o sucesso ou o insucesso da educação escolar, tal como foi adquirida. As variações em relação ao modelo original adquirido somente terão validade se forem projetadas por eles e a partir deles, únicos capazes de escolher os alvos ideais de seu percurso histórico.

Sejam quais forem os resultados obtidos por essa escola, compete aos Guarani avaliá-los e transformá-los se for necessário. À sociedade nacional compete não mais do que fornecer-lhes os recursos necessários para que instalem, quando e como quiserem, a educação escolar em sua(s) aldeia(s).

Nesse caso, de encontro às opiniões que desqualificam a escola tradicional, a educação escolar sempre cumpriu a sua função básica de treinar no manejo de códigos simbólicos diversos, como formas predominantes no pensamento discursivo. Se esse fato não mais ocorrer, será preciso buscar fora da educação formal as suas causas. É possível pensar-se, inclusive, que ela não esteja ocorrendo, como em algumas instituições de ensino público, daí a sua evidente inoperância.

A verificação da eficácia do ensino formal nas aldeias guaranis será, pois, uma decorrência de sua verificação nos intercursos com as sociedades nacional e regional a que estarão sujeitos. Nesse caso, cumpre novamente a eles estabelecer prazo, calendário, língua, tema, etc., a que terão de adequar-se os agentes educadores, cuja origem étnica independe da função em que atuem.

No caso de sua língua tradicional, seu uso é relativo ao ambiente fora da escola. Introduzi-lo forçosamente no ambiente escolar seria tratá-la como a língua "morta-escrita-estrangeira", que Bakhtin descreveu, isto é, uma língua desconhecida, ou um simulacro de sua própria fala. Nesse sentido, é interessante lembrar o que diz Hobsbawm a propósito dessa invenção: 
As linguagens-padrão nacionais que devem ser aprendidas nas escolas e utilizadas na escrita, quanto mais na fala, por uma elite de dimensões irrisórias, são em grande parte, construções relativamente recentes. (1984, p. 22)

Assim, a ideia de construir-se uma língua nacional escrita para os Guarani seria mais propriamente a projeção de um processo pelo qual passaram as línguas nacionais dos países industrializados, sobre as línguas indígenas, no caso o guarani, cujas histórias seguiram percursos diferentes, configurando realidades diferentes em suas adequações sociais.

Se a educação escolar não ameaça o uso da língua tradicional do grupo, entretanto, ela também não garante seu uso. Apenas, ela é capaz de apontar na direção mais acertada, isto é, para além de seus limites, no próprio ambiente de interação do grupo com a sociedade nacional. Clairis salientou que uma língua desaparece quando seus locutores desaparecem (1991, p. 5-6). Nesse caso, os desaparecimentos físico ou social condicionam os meios necessários para que sejam eles mesmos evitados.

A alfabetização requerida pelos índios, no Brasil, desde o século XVI, tem funções bem definidas no interior da cultura que a requer, as quais nem sempre é possível para o observador externo apreender. É necessário entregar-lhes o que desejam e aguardar os resultados, sem perder de vista que o uso da língua tradicional do grupo é, apenas, realizado nos processos informais de transmissão de conhecimento. 


\section{Referências}

Altmann, L.; Zwetsch, R.B. Projeto de educação para o grupo Suruí, Rondônia. In: Silva, A.L. (Org.) A questão da educação indígena. São Paulo: Brasiliense, 1981. p. 44-50.

Azevedo, T. Catequese e aculturação. In: Schaden, E. (Org.). Leituras de etnologia brasileira. São Paulo: Nacional, 1976. p. 365-384.

Bakhtin, M. Marxismo e filosofia da linguagem. Problemas fundamentais do método sociológico na ciência da linguagem. 2. ed. Tradução de Michel Lahud et al. São Paulo: Hucitec, 1981.

Barbosa, H. Historia da Colonisação do Brazil. Rio de Janeiro: Comissão Rondon, 1919.

. O problema indígena do Brasil. Rio de Janeiro: Comissão Rondon, 1926.

Barros, M.C.D.M. Linguística missionária: Summer Institute of Linguistics. 1993. Tese (Doutorado em Linguística)- Unicamp, Campinas, 1993.

BARTH, F. Introduction. In: . (Ed.). Ethnic groups and boundaries. The social organizacion of culture difference. Oslo: Scandinavian University Books, 1969. p. 9-38.

Bartolomé, M.A. Orekuera royhendu. (Lo que escuchamos en sueños). Shamanismo y religión entre los Ava-Katu-Ete del Paraguay. México: Instituto Indigenista Interamericano, 1977.

Beozzo, J.O. Leis e regimentos das missões. Política indigenista no Brasil. São Paulo: Loyola, 1983. 
Bettendorf, J.F. Chronica da missão dos padres da Companhia de Jesus no estado do Maranhão. Revista do Instituto Historico e Geographico Brazileiro, Rio de Janeiro,72, p. 1-697, 1909.

Bispos preparam debate sobre conversão de índios. O Estado de São Paulo, São Paulo, 2 mai. 1992.

Boff, L. América Latina: da conquista à nova evangelização. São Paulo: Ática, 1992.

Bridgeman, L.I. A alfabetização de um povo ágrafo. Mimeo, [s.d.].

Cadogan, L. Ayvu rapyta Textos míticos de los Mbyá-Guaraní del Guairá. Ed. preparado por Bartomeu Melià. Asunción: Fundación "Leon Cadogan"/Ceaduc-Cepag, 1992a.

. Diccionario Mbya-Guarani castellano. Ed. preparada por Fiedl Grünberg. Asunción: Fundación “Leon Cadogan”/Ceaduc-Cepag, 1992b.

Cassirer, E. Linguagem, mito e religião. Tradução de Rui Reininho. Porto: RÉS, 1976.

Castelo-Branco, F. Cartilhas quinhentistas para ensinar a ler. Boletim bibliográfico e informativo, Lisboa, n. 14, p. 109-152, 1971. . Portugal quinhentista visto através das Cartilhas para ensinar a ler. Anais, Lisboa, n. 21, p. 291-315, 1972.

Cherobin, M. Os índios Guarani do litoral do estado de São Paulo. Análise antropológica de uma situação de contato. São Paulo: FFLCH-USP, 1986.

Clairis, C. Le processus de disparition des langues. La linguistique, v. 27, n. 2, p. 3-13, 1991.

CunHA, M.C. Legislação indigenista no século XIX: uma compilação: 1808-1889. São Paulo: Edusp/Comissão Pró-Índio de São Paulo, 1992. 
Documento final do encontro. In: Silva, A.L. (Org.) A questão da educação indígena. São Paulo: Brasiliense, 1981. p. 149-150.

Dooley, R. Vocabulário básico do Mbyá Guaraní. 2. ed. rev. Brasília: S.I.L., 1990.

Dumont, L. Homo hierarchicus. O sistema das castas e suas implicações. Tradução de Carlos Alberto da Fonseca. São Paulo: Edusp, 1992.

Edelweiss, F. G. Estudos tupis e tupi-guaranis. Confrontos e versões. Rio de Janeiro: Brasiliana, 1969.

Ekdahl, B.; Butler, N. Explicação do alfabeto terena. Brasília: S.I.L., 1994.

Emiri, L.; Monserrat, R. A conquista da escrita - encontros de educação indígena. São Paulo: OpAn/Iluminuras, 1989.

Ferguson, C.H. Diglossia. Word, v. 15, n. 1, p. 325-340, 1959.

Fernandes, F. A investigação etnológica no Brasil e outros ensaios. Petrópolis: Vozes, 1975.

Ferreira, M.K.L. Da origem dos homens à conquista da escrita: um estudo sobre povos indígenas e educação escolar no Brasil. 1992. Dissertação (Mestrado em Antropologia) - FFLCH-USP, São Paulo, 1992.

Ferreiro, E.; Teberosky, A. Los sistemas de escritura en el desarrollo del niño. 2. ed. México: Siglo Veinteuno, 1980.

Fishman, J.A. Bilingualism with and without diglossia; diglossia with and without bilingualism. Journal of Social Issues, v. 23, n. 2, p. 29-38, 1967.

. Bilingualism and biculturism as individual and as societal phenomena. Journal of Multilingual and Multicultural Development, v. 1, n. 1, p. 3-15, 1980. 
Franchetto, B. Um histórico do Summer Institute of Linguistics. Suas entradas e saídas. Religião e Sociedade, Rio de Janeiro, n. 7, p. 68-73, 1981.

FunaI. Convênio n $n^{\circ}$ 028/83, que entre si celebram a Fundação Nacional do Índio - FUnAI - e o Summer Institute of Linguistics - Instituto Linguístico de Verão. Mimeo, 1983.

Gagliardi, J.M. O indígena e a república. São Paulo: Hucitec/ EDUSP/Secretaria do Estado da Cultura de São Paulo, 1989.

GeERTz, C. A interpretação das culturas. Rio de Janeiro: Guanabara, 1989.

Gnerre, M. Linguagem, escrita e poder. 3. ed. São Paulo: Martins Fontes, 1991.

Goodman, K.S. O processo de leitura: considerações a respeito das línguas e do desenvolvimento. In: Ferreiro, E.; Palacio, M.G. (Coords.) Os processos de leitura e escrita: novas perspectivas. 3.ed. Tradução de Maria Luiza Silveira. Porto Alegre: Artes Médicas, 1990. p. 11-22.

Hall, J. Os sistemas fonológicos e gráficos xavante e português. Análise contrastiva. Brasília: S.I.L., 1979.

HALE, K. Language endangerment and the human value of linguistic diversity. Language, v. 68, n. 1, p. 35-42, 1992.

Hobsbawm, E. Introdução: a invenção das tradições. In: HobSBAWM, E.; Ranger, T. (Orgs.). A invenção das tradições. Tradução de Celina Cardim Cavalcante. Rio de Janeiro: Paz e Terra, 1984. p. 9-23.

Ihering, H. A questão dos indios no Brazil. Revista do Museu Paulista, São Paulo, n. 8, p. 112-140, 1911. 
JAKobson, R. À procura da essência da linguagem. In:

Linguística e comunicação. 10. ed. Tradução de Izidoro Blikstein e José Paulo Paes. São Paulo: Cultrix, [s.d.]. p. 98-117.

Kato, M. O aprendizado da leitura. 3. ed. São Paulo: Martins Fontes, 1990.

Kindell, G.E.; Jones, J.W. Educação indígena: metodologia e programação. Brasília: S.I.L., 1978.

Krauss, M. The world's languages in crisis. Language, v. 68, n. 1, p. 4-10, 1992.

KRUG, E. Os índios das margens do Paranapanema. Revista do Instituto Histórico e Geográfico de São Paulo, São Paulo, n. 21, p. 319-347, 1924.

LACERDA, I.B. Acampamento de índios guaranis nos municípios de Itanhaém e Itariri. Revista do Instituto Geográfico e Geológico, São Paulo, v. 12, n. 3, p. 237-249, 1954.

LAdefoged, P. A course in phonetics. 2. ed. New York: Harcourt Brace Jovanovich, 1989.

LAdEIRA, M.E. Sobre a língua da alfabetização indígena. In: SiLVA, A.L. (Org.) A questão da educação indígena. São Paulo: Brasiliense, 1981. p. 171-173.

Ladeira, M.I. Atividade da escola da aldeia Guarani da Barragem, São Paulo. In: Silva, A.L. (Org.) A questão da educação indígena. São Paulo: Brasiliense, 1981. p. 112-122.

- "O caminhar sob a luz" - O território Mbyá à beira do oceano. 1992. Dissertação (Mestrado em Ciências Sociais) - PuC-SP, São Paulo, 1992. 
LEA, V. Um projeto de alfabetização na língua portuguesa elaborado para índios Txucarramães (Kayapó) do Parque Nacional do Xingu. In: Silva, A.L. (Org.) A questão da educação indígena. São Paulo: Brasiliense, 1981. p. 58-68.

Leite, S. Novas cartas jesuíticas (de Nóbrega a Vieira). São Paulo: Nacional, 1940.

Cartas dos primeiros jesuítas do Brasil I (1538-1553). São Paulo: Comissão do IV Centenário da Cidade de São Paulo, 1954a.

. Cartas dos primeiros jesuitas do Brasil II (1553-1558). São Paulo: Comissão do IV Centenário da Cidade de São Paulo, 1954b.

. Cartas dos primeiros jesuitas do Brasil III (1558-1563). São Paulo: Comissão do IV Centenário da Cidade de São Paulo, 1954c.

LeIte, Y. O Summer Institute of Linguistics. Estratégias e ação no Brasil. Religião e Sociedade, Rio de Janeiro, n. 7, p. 60-64, 1981.

LeITE, Y. et al. O papel do aluno na alfabetização de grupos indígenas: a realidade psicológica das descrições linguísticas. Boletim do Museu Nacional, Rio de Janeiro, n. 55, p. 1-23, 1985.

LÉvi-STrauss, C. Raça e história. 4. ed. Tradução de Inácia Canelas. Lisboa: Presença, 1989.

Loyola, I. Obras completas. 4. ed. rev. Madrid: La Editorial Catolica, 1982.

Manacorda, M.A. História da educação: da Antiguidade aos nossos dias. 3. ed. Tradução de Gaetano Lo Monaco. São Paulo: Cortez/Autores Associados, 1992. 
Meggers, B.J. Amazônia: a ilusão de um paraíso. Tradução de Maria Yedda Linhares. Belo Horizonte: Itatiaia; São Paulo: EDUsP, 1987.

Melıá, B. Educação indígena e alfabetização. São Paulo: Loyola, 1979. . A experiência religiosa guarani. In: MARZAL, M. M. et al (Orgs.). O rosto índio de Deus. Tradução de Jaime S. Clasen. São Paulo: Vozes, 1989. p. 293-357.

Missionários ou colonizadores. Cadernos do Terceiro Mundo, n. 50, p. 31-33, 1982.

Monserrat, R.M.F. Vale a pena alfabetizar 28 pessoas? Cadernos de Estudos Linguísticos, Campinas, n. 4, p. 115-121, 1983.

. Parakanãs, língua, escola e educação. Jornal do Brasil, 15 jul. 1991.

Moreira Neto, C. A. Índios da Amazônia, de maioria a minoria (1750-1850). Petrópolis: Vozes, 1988.

Mullet, M. A contra-reforma e a reforma católica nos princípios da idade moderna europeia. Lisboa: Gradiva, 1985.

Nascimento, N.F. Uma experiência em educação bilíngue com o povo Maxakalí. Cadernos de Estudos Linguísticos, Campinas, n. 4, p. 155-164, 1983.

NAUD, L. Documentos sôbre o índio brasileiro (1500-1822): $1^{a}$ parte. Revista de Informação Legislativa, São Paulo, n. 28, p. 437-520, 1970. . Documentos sobre o índio brasileiro. (1500-1822): $2^{\text {a }}$ parte. Revista de Informação Legislativa, São Paulo, n. 28, p. 229-336, 1971. Newman, B. O indígena brasileiro e educação. Palestra dada pela Bárbara A. Newman no $1^{\circ}$ Seminário Fundação Nacional do Índios/ Missões Religiosas. Brasília: S.I.L. Mimeo, 1973. 
Ensino bilíngue: uma ponte para a integração. Informativo Funai, v. 4, n. 14, p. 67-75, 1975.

Nimuendaju, C. As lendas da criação e destruição do mundo como fundamentos da religião dos Apapocúva-Guarani. Tradução de Charlotte Emmerich e Eduardo Viveiros de Castro. São Paulo: Hucitec/Edusp, 1987.

Novaes, S.C. Jogo de espelhos, imagens da representação de si através dos outros. 1990. Tese (Doutorado em Antropologia) FFLCH-USP, São Paulo, 1990.

Oliveira, H. Coletânea de leis, atos e memoriais referentes ao indígena brasileiro. Rio de Janeiro: Imprensa Nacional, 1947.

Oliveira, M.C.M.; Diniz, K. A escola kaxi. In: Silva, A.L. (Org.) A questão da educação indígena. São Paulo: Brasiliense, 1981. p. 30-37.

Oliveira, R.C. Deve o Summer permanecer no Brasil? Religião e Sociedade, Rio de Janeiro, n. 7, p. 66-67, 1981.

Peirce, C.S. O ícone, o indicador e o símbolo. In: Semiótica e filosofia. 2. ed. Tradução de Octanny S. da Mota e Leonidas Hegenberg. São Paulo: Cultrix/EdusP, 1975. p. 115-134

REY, M.J.B. Antropología de la mujer: cognición, lengua e ideología cultural. Barcelona: Anthropos, 1988.

RodRIGUeS, A. Línguas brasileiras: para o conhecimento das línguas indígenas. São Paulo: Loyola, 1986.

. No Brasil, 85\% das línguas indígenas já estão extintas.

Ciência Hoje (encarte), n. 83, p. 5, 1992.

Sampaio, T. A "Revista". Revista da Sociedade de Etnografia e Civilização dos Índios, v. 1, n. 1, 1901. 
SAPIR, E. La realidad psicológica de los fonemas. Tradução de F.E. Pais. In: Delacroix, H. (Org.) Psicología del lenguaje. Buenos Aires: Paidos, 1947 p. 161-174

. A linguagem: introdução ao estudo da fala. 2. ed. Tradução de J. Mattoso Camara Jr. Rio de Janeiro: Acadêmica, 1971.

Saussure, F. Curso de linguística geral. 8. ed. Tradução de Antônio Chelini et al. São Paulo: Cultrix, 1977.

Schaden, E. Aculturação indígena. Ensaio sôbre fatôres e tendências da mudança cultural de tribos em contacto com o mundo dos brancos. São Paulo: Pioneira/Edusp, 1969.

. Aspectos fundamentais da cultura guarani. 3. ed. São Paulo: E.P.U./EDUSP, 1974a.

. Educação indígena. Revista do Arquivo Municipal, São Paulo, v. 37 , p. 7-31, 1974b.

- A mitologia heróica de tribos indígenas do Brasil. Ensaio etnossociológico. 3. ed. São Paulo: Edusp, 1989.

SCribner, S.; Cole, M. Cognitive consequences of formal and informal education. New accommodations are needed between school-based learning experiences of everyday life. Science, n. 182, p. 553-559, 1973.

Seeger, A. Deve o Summer operar no Brasil? Religião e Sociedade, n. 7, p. $65,1981$.

Silva, J.B.A. Apontamentos para a civilização dos indios bárbaros do reino do Brasil. Edição crítica preparada por G. Boehrer. Lisboa: Agência-Geral do Ultramar, 1963.

Stauffer, D.H. Origem e fundação do Serviço de Proteção aos índios. Tradução de J. Philipson. Revista de História, São Paulo, n. 37, p. 73-95, 1959. 
Summer Institute of Linguistics. Bibliografia. Brasília: S.I.L., 1973. . Bibliografia: 1973-1980. Brasília, S.I.L., 1981.

VAnsina, J. A tradição oral e sua metodologia. In: Ki-Zerbo, J. (Org.) História geral da África I. Metodologia e pré-história da África. Tradução de Beatriz Turquetti e outros. São Paulo: Ática; Paris: Unesco, 1982. p. 157-179.

VIeIRA, A. Escritos instrumentais sobre os índios. São Paulo: Educ/ Loyola/Giordano, 1992.

WALD, P. Língua materna. Produto de caracterização social. In: Vermes, G.; Boutet, J. (Orgs.) Multilinguismo. Tradução de Celene M. Cruz et al. Campinas: Editora da Unicamp, 1989. p. 89-107.

Wilson, J. Índio lerá nos seus dialetos. Revista Brasileira de Estudos Pedagógicos, n. 51, p. 170-173, 1969. 